\title{
A TALE OF TWO LEVELS: DIVERSIFICATION OF BUSINESS GROUPS
}

\author{
A Dissertation \\ by \\ DONG WOOK HUH \\ Submitted to the Office of Graduate and Professional Studies of \\ Texas A\&M University \\ in partial fulfillment of the requirements for the degree of \\ DOCTOR OF PHILOSOPHY
}

$\begin{array}{ll}\text { Chair of Committee, } & \text { Lorraine Eden } \\ \text { Committee Members, } & \text { Michael A. Hitt } \\ & \text { Mario Schijven } \\ & \text { Hiroshi Ono } \\ \text { Head of Department, } & \text { Ricky W. Griffin }\end{array}$

August 2014

Major Subject: Management

Copyright 2014 Dong Wook Huh 


\begin{abstract}
Typical business groups are widely diversified into unrelated industries.

Scholars have explained this as a consequence of institutional weaknesses and predicted that business groups would lose their effectiveness and increasingly refocus as institutional environments improve.

In this dissertation, I suggest a new perspective on business groups by revisiting their hybrid nature and focusing on the fact that two different boundaries exist for business group member firms. I differentiate between group-level diversification and firm-level diversification and argue that they serve different purposes, which lead to divergent patterns of diversification.
\end{abstract}

First, at the business group level, I question the appropriateness of applying the concept of relatedness to the diversification of a business group. Emphasizing the hybrid nature of the business group, I argue that its purpose of diversification may be more to provide the group's member firms with critical resources than to obtain synergies from operating in related industries. Relying on the insights from the inputoutput model, I propose the idea that business groups are more likely to enter industries that have linkages to multiple other industries than to follow the relatedness criterion. I test the idea using the data of 30 major South Korean business groups' diversification from 1999 to 2008 and find an empirical support.

Second, at the member firm level, I focus on the importance of group-level characteristics on member firms' diversification choices. Emphasizing economic 
incentives, I propose that the business group structure and relationships within it affect its member firms' strategic orientation and choices in ways that may satisfy the needs of both the controlling shareholders and minority shareholders. I theorize that the size, the degree of diversification, and the proportion of intragroup transaction of a business group would affect diversification choices of its member firms. Based on the data of 108 public member firms of 30 major South Korean business groups, I find empirical support for most of my hypotheses.

The implication of my dissertation is that the business group may be not just a coping mechanism for underdeveloped institutions, but an organizational innovation that can work in any institutional environment. 


\section{DEDICATION}

I dedicate this dissertation to my family, especially my mother, with whom I have not been able to spend much time together ever since I first came to the United States in 2002. I always wish I were a better son for my mother and better brother for my two sisters. I would also like to remember my late father, who always emphasized the value of learning and education. Without my family, I would be nothing. 


\section{ACKNOWLEDGEMENTS}

The past five years that I spent as a doctoral student has not been a very productive period for me in terms of tangible results. Many doubts and suspicions regarding myself, the field of strategic management, and the academia in general have dogged me and the feeling that I am not even close to my ideal of the scholar has constantly frustrated and humbled me. I have to confess that I often withdrew to myself when I needed most to reach out and get help from the faculty and fellow doctoral students. I think if I had opened up more, I would have had a much easier time solving my problems and developing ideas.

On the other hand, however, I believe that a healthy dose of skepticism and selfdoubt is just an indication that the mind is still working. It may also be a vital ingredient in any serious academic undertaking. Additionally, all the mental and psychological struggles that I went through during the doctoral program made it easier for me to see the world in the perspective of a struggling student or a person that goes through any kind of difficulty in general. I hope I will be able to make a meaningful difference in the world through the work I do and the students that I teach.

My dissertation committee chair, Dr. Lorraine Eden, always seemed to have more confidence in me than I could ever muster myself. Whenever I struggled and had a hard time finding my way, she patiently provided guidance and assured me of the value of my ideas. Her fierce pursuit of perfection and unwavering candor, which startled me 
at times, will be fondly remembered for the rest of my life. Though she is extremely professional, she is much more than just a professor to me.

It is amusing that each of my dissertation committee members is from a different country. Dr. Eden is from Canada, Dr. Michael A. Hitt from the United States, Dr. Mario Schjiven from the Netherlands, and Dr. Hiroshi Ono from Japan. I could have done a much better job picking everyone's brain a little better, but I am just so honored to have such distinguished scholars on my dissertation committee. I will always remember Dr. Hitt's friendly wink at me at the end of almost every conversation. Dr. Schjiven is moving to the University of Illinois at Urbana-Champaign this summer and I hope he will keep accomplishing great things down the road. Dr. Ono is moving soon to Hitotsubashi University in Japan. He opened my eyes to the fascinating field of economic sociology. His seminar stirred the "sociological imagination", which had lain dormant in me for a long time since I stole and read C. Wright Mills' book from my big sister's collection when I was still a high school student.

I would like to thank everybody on the faculty of the Department of Management for all the support and encouragements throughout my years at Mays Business School. Special thanks go to Dr. Michael Withers, Dr. Asghar Zardkoohi, Dr. Richard W. Woodman, Dr. Laszlo Tihanyi, Dr. Ramona L. Paetzold, Dr. R. Duane Ireland, Dr. Gerald David Flint, Dr. Michael W. Pustay, and Dr. Wendy R. Boswell. I also want to show my gratitude to Sabrina Saladino, Valerie Gootee, Argie Butler, Patsy Hartmangruber, and Phyllis Washburn, who made my life easier on any given day at the department. Additionally, I would like to thank Dr. Brad L. Kirkman, Dr. Oi-Man 
Kwok, Dr. Victor Willson, Dr. Jane Sell, and Dr. Alina Sorescu for giving me knowledge and insights through their exceptional teaching and guidance.

It is a shame that I have to bid farewell to the most attentive and thorough doctor I have ever had, Dr. Audrey Ormberg at Texas A\&M Student Health Services. She took care of my "aging" body so well during the most stressful period of my life. She quipped, "Wait until you become my age." I hope I will be able to smile and laugh like her when I get there even though I honestly think that she cannot be much older than I am.

I was able to build meaningful relationships with many good friends during my years at Texas A\&M University. I hope I will be able to keep in touch with them and we will be able to do good work together to make this world a little bit better. Most importantly, I was able to find my love at Texas A\&M University. Even just for that, I think all the suffering was worthwhile. While cherishing the memories of Texas A\&M dearly, I will move on to find and serve my purpose in life.

A dear friend of mine, Jennifer, kindly proofread the whole dissertation one last time. She has been my de facto English teacher for more than a decade and is an actual high school English teacher. Any error that remains is mine. 


\section{TABLE OF CONTENTS}

Page

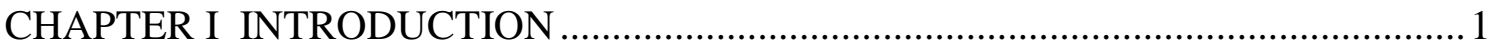

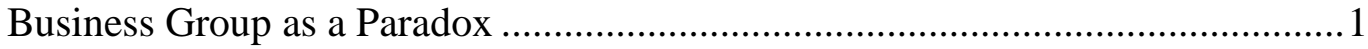

Purpose and Approach of the Dissertation ....................................................... 3

Empirical Test of the Ideas......................................................................... 8

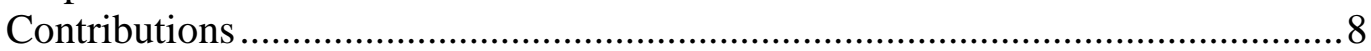

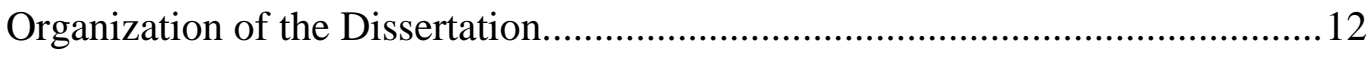

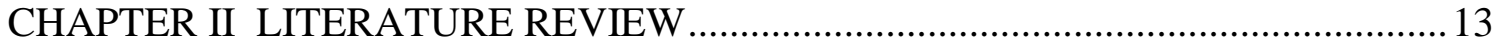

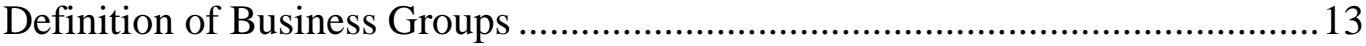

Theoretical Approaches to Business Groups ................................................ 16

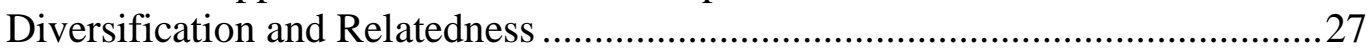

CHAPTER III GROUP-LEVEL DIVERSIFICATION AND INTER-INDUSTRY

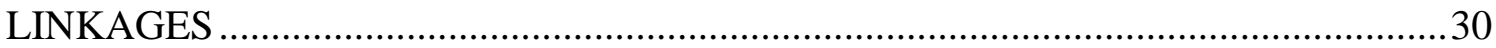

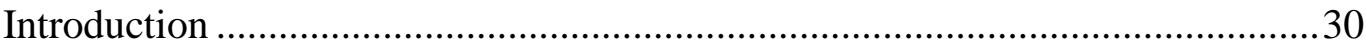

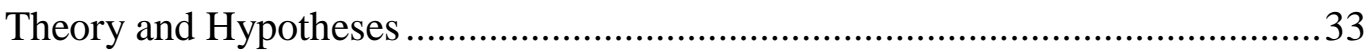

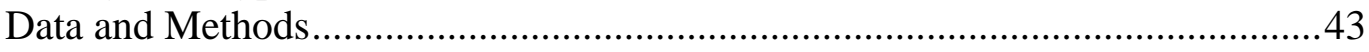

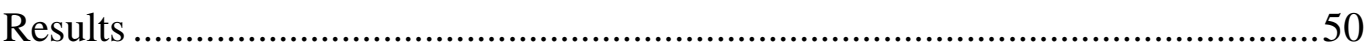

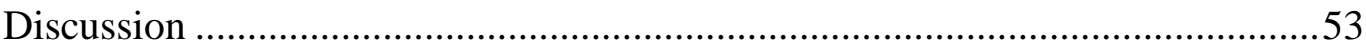

CHAPTER IV BUSINESS GROUP MEMBER FIRM DIVERSIFICATION

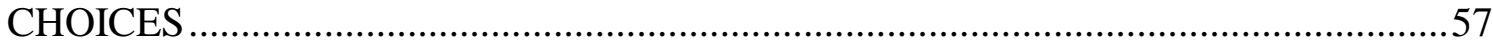

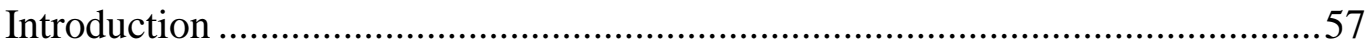

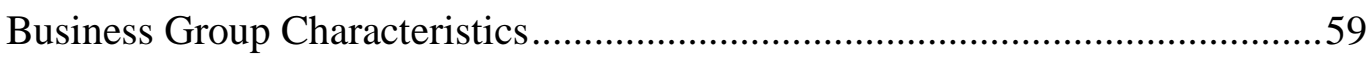

Group Member Firms' Diversification Choices.............................................66

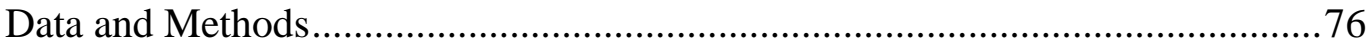

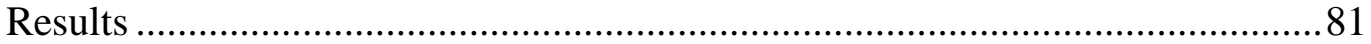

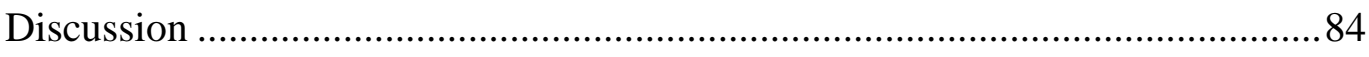

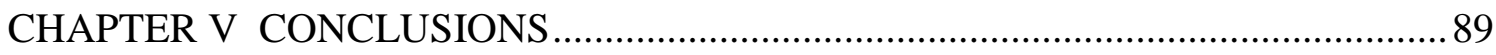

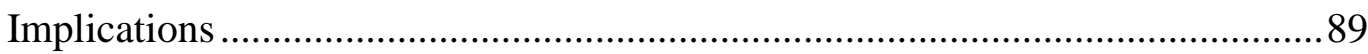

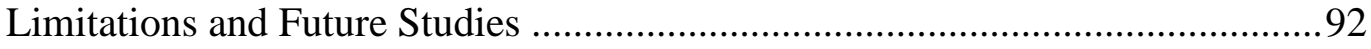

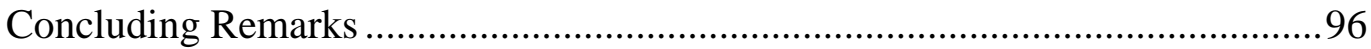

viii 


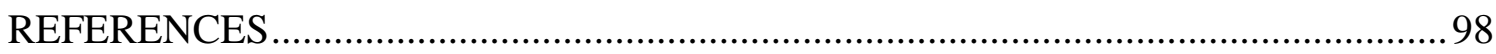

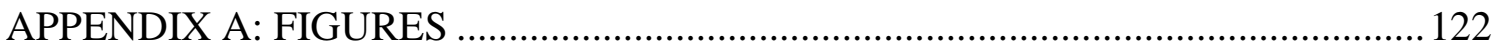

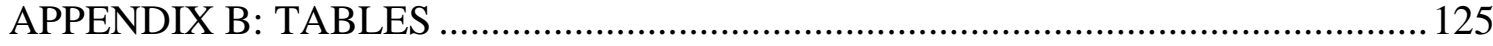




\section{LIST OF FIGURES}

Page

Figure 1. Two levels of boundaries of a business group ....................................... 122

Figure 2. Model for business group diversification ........................................... 123

Figure 3. Model for business group member firm diversification ............................. 124 


\section{LIST OF TABLES}

Page

Table 1. Top 30 business groups in Korean economy (in 10 billion Korean Won)....... 125

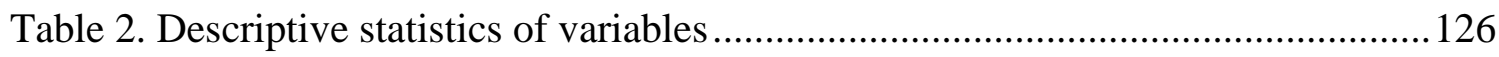

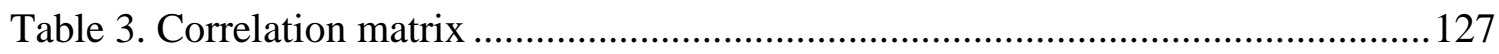

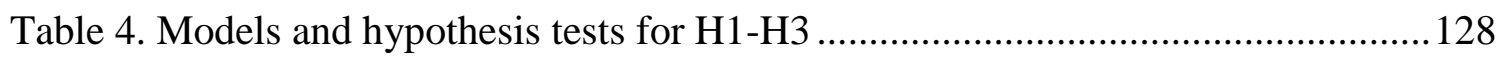

Table 5. Industry presence of business groups ................................................. 129

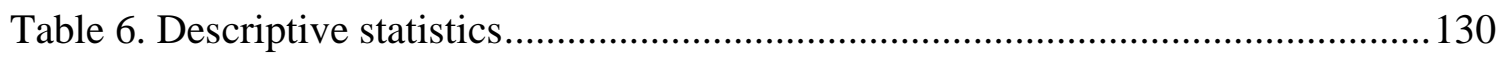

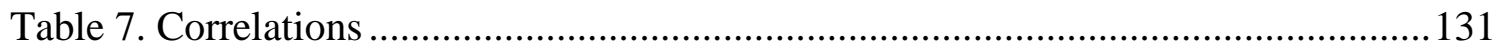

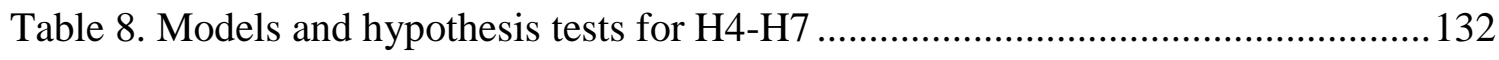

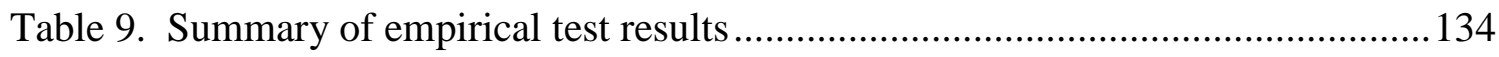




\section{CHAPTER I}

\section{INTRODUCTION}

"My father and I started a cosmetic cream factory in the late 1940s. At the time, no company could supply us with plastic caps of adequate quality for cream jars, so we had to start a plastics business. Plastic caps alone were not sufficient to run the plastic molding plant, so we added combs, toothbrushes, and soap boxes. This plastics business also led us to manufacture electric fan blades and telephone cases, which in turn led us to manufacture electrical and electronic products and telecommunication equipment. The plastics business also took us into oil refining, which needed a tanker shipping company. The oil refining company alone was paying an insurance premium amounting to more than half the total revenue of the then largest insurance company in Korea. Thus, an insurance company was started. This natural step-by-step evolution through related businesses resulted in the Lucky-Goldstar group as we see it today." (Koo Cha-Kyung, former chairman of the LG Group, as quoted in Milgrom \& Roberts, 1992:542-543)

\section{Business Group as a Paradox}

Business groups - collections of legally independent firms that are owned or controlled by the same person or persons (Cainelli \& Iacobucci, 2011) who are usually family members (Chang \& Hong, 2000; La Porta, Lopez-de-Silanes, \& shleifer, 1999; Morck, Wolfenzon, \& Yeung, 2005; Morck \& Yeung, 2003) - seem to defy some of the major tenets of strategic management. Scholars mostly agree that unrelated diversification is harmful (Palich, Cardinal, \& Miller, 2000; Wan, Hoskisson, Short, \& Yiu, 2011), but business groups are typically diversified widely to unrelated industries (Khanna \& Rivkin, 2001; Kock \& Guillén, 2001). Moreover, the presence of the controlling shareholders presiding over a wide variety of listed and unlisted member firms is believed to be a threat to the ideal of strong corporate governance because the 
controlling shareholders may destroy value by pursuing their own interest at the expense of minority shareholders (Bae, Kang, \& Kim, 2002; Bertrand, Mehta, \& Mullainathan, 2002; Chang, 2003). Indeed, many studies on business groups focus on their dark side: how they can only exist and prosper in environments characterized by poor institutions (Khanna \& Palepu, 2000a, b; Leff, 1978) or foreign trade and investment asymmetries (Guillén, 2000; Kock \& Guillén, 2001); and how controlling shareholders of business groups may "tunnel" resources from one member firm to another (Bertrand et al., 2002; Chang, 2003; Johnson, La Porta, Lopez-de-Silanes, \& Shleifer, 2000) or divert resources to prop up weaker, inefficient member firms (Friedman, Johnson, \& Mitton, 2003; Jia, Shi, \& Wang, 2013) to pursue their own benefits. ${ }^{1}$

Given these negative accounts for business groups, their ongoing persistence and prevalence around the world even as national economies mature under the strong influence of globalization may be called paradoxical (Manikandan \& Ramachandran, 2014). Despite the prediction that diversified business groups in emerging markets will increasingly undertake corporate refocusing (Hoskisson, Johnson, Tihanyi, \& White, 2005), evidence suggests otherwise. For example, business groups in India, one of the major emerging markets, became larger and more diversified instead of smaller and more focused as the Indian economy liberalized between 1989 and 2008 (Siegel \& Choudhury, 2012).

\footnotetext{
${ }^{1}$ Johnson et al. (2000:1) define tunneling in the abstract as "the transfer of assets and profits out of firms for the benefit of their controlling shareholders". Friedman et al. (2003: 735) describe propping as "negative tunneling".
} 
Moreover, even though academic research on business groups tends to focus on those in emerging markets, business groups are an important part of many developed economies as well (La Porta et al., 1999; Langlois, 2010; Morck et al., 2005). According to Morck et al. (2005), a single business group accounts for half the market capitalization in Sweden and the largest ten business groups constitute $40 \%$ of the market capitalization in Canada, while the assets of the largest fifteen business groups amount to over $80 \%$ of Hong Kong's gross domestic product (GDP). The United States and the United Kingdom, countries where business groups are not prominent - large firms there are mostly held widely and do not control other listed firms due to legal constraints and prohibitions ${ }^{2}$ - are rare exceptions rather than the norm (Granovetter, 1995; Kandel, Kosenko, Morck, \& Yafeh, 2013; Langlois, 2010; Morck et al., 2005).

\section{Purpose and Approach of the Dissertation}

If business groups are prone to exclusively benefit controlling shareholders at the expense of minority shareholders, why are outside investors still interested in business group member firms and why do business groups keep expanding? If business groups are organized to exploit weak institutions, why do business groups continue to be relevant in improved and advanced institutional environments?

This dissertation explores potential reasons for the resilience and success of business groups by revisiting their nature as a "hybrid" organizational form (Williamson,

\footnotetext{
${ }^{2}$ For example, in the U.S. the Glass-Steagall Act (1933) prohibits banks from owning stock of industrial companies and the Investment Company Act (1940) makes it impossible for a company to manage another company without actually own it. In the U.K., in 1968, the London Stock Exchange started to require that anyone acquiring 30 percent of a publicly traded firm should acquire 100 percent of the firm.
} 
1991). Because a business group is a collection of firms, a business group has two different boundaries. Each business group member firm has its own boundary, and the member firm is also placed inside another, larger boundary, that of the business group. Figure 1 shows a stylized graphical example. The business group boundary is depicted as a dashed line to convey the idea that the business group is rarely a legal entity. For a member firm, the business group represents a special market-like environment in which it enjoys relationships and transactions based on trust and shared values (Das \& Teng, 1998; Keister, 1998; Manikandan \& Ramachandran, 2014). Therefore, business groups have characteristics of firms as well as those of markets.

This hybrid nature of business groups has not been fully examined because prior studies have made approximations in an effort to apply existing theories about the firm such as transaction cost theory, agency theory, and resource-based theory - to the business group. First, most studies of business groups have focused on the level of business group member firms by comparing them with stand-alone firms (e.g., Ferris, Kim, \& Kitsabunnarat, 2002; Khanna \& Palepu, 2000a; Khanna \& Palepu, 2000b; Khanna \& Rivkin, 2001). Even though this approach provides us with a way to understand the economic impact of business groups, the approach reduces the complex phenomenon of business groups just to a matter of membership. On the other hand, some scholars consider the hierarchy to exist at the group level and regard business group member firms as divisions of a conglomerate (e.g., Chang \& Choi, 1988; Chang \& Hong, 2000; Guillén, 2000). However, this second approach has the danger of ignoring or downplaying (1) the autonomy of legally independent group member firms, (2) the 
ties and transactional relationships among member firms, and (3) the business group's market-like characteristics.

The basic premise this dissertation puts forth is that the controlling shareholders of a business group may not want, and may not have, to exercise blanket control over all the member firms. Indeed, with cognitive and physical limitations, it may not be realistic to expect the controlling shareholders to manage a large business group as tightly as some prior research works have assumed (e.g., Chang \& Choi, 1988; Chang \& Hong, 2000; Hoskisson et al., 2005). I propose that by designing and controlling the overall group structure, the controlling shareholders may be able to help define linkages among member firms and give each member firm unique economic incentives to play an appropriate role within the business group structure. The implication is that member firms will try to choose and pursue strategies in order to reap the maximum possible benefits of group membership. In turn, if the group is structured in a desirable way, the controlling shareholders will benefit without having to get involved in every detail of every business. A recent finding that structures of business groups are formed more as the result of sequential delegation of authority than as the consequence of controlmagnifying intention (Belenzon, Patacconi, \& Zelner, 2012b) is consistent with this view. Moreover, given the inherent incompleteness of strategic factor markets, building an appropriate market-like environment within the boundary of the business group may contribute positively to the growth potential of the group's member firms (Manikandan \& Ramachandran, 2014). 
This dissertation specifically focuses on the diversification ${ }^{3}$ of business groups and their member firms (Hitt, Hoskisson, \& Ireland, 1994). Because a business group is formed when a specific type of diversification - setting up a separate legal entity instead of diversifying the existing firm further - is pursued, the most crucial group-level characteristics have to do with the diversification pattern of the business group. Business groups are often characterized in the literature as a quintessential example of unrelated diversification (Hoskisson et al., 2005; Khanna \& Rivkin, 2001; Kock \& Guillén, 2001), but in reality, degrees of diversification in business groups do vary and how they approach diversification may be different as well. This dissertation examines business group diversification at two different levels: the business group level and the member firm level.

On the business group level, I propose that diversification at this level should not be examined solely based on the relatedness criterion (Palich et al., 2000; Rumelt, 1974; Wan et al., 2011) given the market-like nature of the business group. Typical business groups are widely diversified into unrelated industries, which scholars have explained as a consequence of institutional weaknesses (Khanna \& Rivkin, 2001; Kock \& Guillén, 2001). However, I suggest the possibility that this seemingly non-strategic and inefficient diversification pattern may actually be a way for a business group to take advantage of the linkages among different industries to provide its member firms with

\footnotetext{
${ }^{3}$ Diversification can refer to both product diversification, "expansion into product markets new to the firm" and international diversification, "expanding across country boarders into geographic locations (e.g., markets) that are new to the firm" (Hitt et al., 1994: 298). However, in this dissertation, diversification only means product diversification unless otherwise noted.
} 
critical resources to spur the member firms' growth. Relying on insights from Leontief's (1986) input-output model, I propose that business groups are more likely to enter industries that have linkages to multiple other industries than to follow the relatedness criterion. I argue that, given the business group's market-like nature, the business group's purpose of diversification (provision of critical resources to member firms) should differ from the purpose of the firm (creation of synergies from operating in related industries).

On the member firm level, I propose that various characteristics of the business group affect a member firm's diversification choices. The logic is that group-level characteristics imply that each member firm has a unique set of roles and characteristics within the business group, and that each member firm will pursue strategic options that will maximize the benefits of its membership to the business group. Therefore, I argue that member firms' diversification patterns will differ depending upon the characteristics and diversification pattern of the business group to which the firms belong. Additionally, I suggest that for business group member firms, whether they are diversifying into an unrelated industry should be determined more carefully than for stand-alone firms because business group member firms may be able to realize synergies even when they seem to enter an unrelated industry if there is another member firm of the same business group in the industry thanks to the special market environment characterized by trust and shared values (Manikandan \& Ramachandran, 2014). 


\section{Empirical Test of the Ideas}

I test the ideas in this dissertation using a sample of 30 major South Korean business groups and their listed non-financial member firms from 1999 to 2008. South Korea is an ideal testing ground for the ideas because business groups dominate the country's economy. Moreover, since the 1997-1998 Asian financial crisis, the institutional environment of the country has improved immensely. However, business groups have continued to flourish, strengthening their competitive advantage rather than withering away from inefficiency.

Table 1 shows that the top 30 business groups in South Korea collectively account for a substantial portion of the country's gross domestic product (GDP). In 2008, the total assets and the total sales of the 30 largest business groups amounted to approximately 84 percent and 85 percent of the country's GDP, respectively. Even though there are changes in the composition of business groups and yearly fluctuations in financial details over the decade from 1999 to 2008, the table indicates that major business groups continue to take up a significant portion of South Korea's national economy. Furthermore, as the financial impacts of the Asian financial crisis wear off, major South Korean business groups appear to be growing even faster and expanding their influence even further.

\section{Contributions}

This dissertation makes several contributions to the business group literature and the diversification literature. 


\section{To the literature on business groups}

This dissertation makes several major contributions to the business group literature. First, the dissertation looks inside each business group rather than treating all business groups as homogeneous. Most prior studies of business groups focus primarily on the economic efficiency of business group membership, through comparisons of group member firms' performance with that of stand-alone firms (Khanna \& Palepu, 2000a, b; Khanna \& Rivkin, 2001; Siegel \& Choudhury, 2012). Such an approach assumes that business groups are homogeneous and that firms benefit or lose from membership universally. I challenge these assumptions by sorting out different diversification characteristics of business groups and focusing on each member firm's incentives to take advantage of the business group characteristics, which collectively define the special market-like environment in which the member firm operates.

Second, I provide a new way of thinking about the nature of business group diversification by differentiating it from that of firm-level diversification. Prior studies have examined business groups either at the firm level (e.g., Guillén, 2000; Khanna \& Palepu, 2000b; Kim, Hoskisson, Tihanyi, \& Hong, 2004) or at the group level (e.g., Chung \& Luo, 2008; Luo \& Chung, 2005; Mahmood, Chung, \& Mitchell, 2013; Mahmood \& Lee, 2004; Mahmood \& Mitchell, 2004; Yiu, Bruton, \& Lu, 2005) assuming that hierarchy exists at just one level. I argue that group-level diversification should be examined as a separate and different (but related) phenomenon from that of firm-level diversification because the purpose of the former is different from that of the latter. 
Third, I further suggest there is a linkage between the two forms of diversification: a business group's diversification characteristics may affect its member firms' diversification strategies. This opens the door for the possibility that setting up a certain business group structure may lead to desirable strategic outcomes for member firms. I propose that the business group form may generate economic incentives for member firms (both carrots and sticks) by posing structural constraints on member firms' diversification while providing resources on which member firms can draw. Prior studies, even when they examine the internal mechanisms of business groups, tend to focus simply on how business group member firms can benefit from resources available within the group structure (Chang \& Hong, 2000; Mahmood, Zhu, \& Zajac, 2011). I counterbalance this by considering the fact that incentives for the business group member firm arise from structural constraints as well as resource endowments. By highlighting economic incentives within the business group, I suggest that the business group as an organizational form should be seen as an organizational innovation set up to satisfy the diverse and often conflicting needs of the controlling shareholders and other shareholders (Manikandan \& Ramachandran, 2014). Thus, I argue that the business group should be seen through a positive lens rather than the "dark side" perspective that regards the business group as an organizational form that can only keep its relevance and advantage by bridging institutional deficiencies and exclusively benefits the controlling shareholders at the expense of minority shareholders. 


\section{To the literature on diversification}

Additionally, this dissertation also makes contributions to the diversification literature. First, prior research on diversification has mostly focused on the relationship between the degree of diversification and financial performance. Because the focus has been primarily on how diversified a firm is, the pattern of its diversification - the portfolio of industries in which the firm operates and the choices it makes over time to build up the portfolio - has not been highlighted (Lemelin, 1982). However, from the perspective of managers and stakeholders of a firm, it may be more helpful to know what industries to enter and how to build an appropriate portfolio of activities than to know whether the firm is at the optimum level of diversification. The relatedness criterion may provide managers with enough insight on how to deal with issues surrounding diversification. However, a more complete picture may emerge when industry characteristics and interrelationships among different industries are considered together with firm characteristics. This dissertation suggests a way to combine these considerations to understand diversification in a different light.

Second, this dissertation suggests that firms and business groups may have different purposes for diversification. I develop a theory of business group diversification based on inter-industry linkages rather than rely on the firm-level theories of diversification based on relatedness in order to consider the market-like nature of the business groups. The concept of inter-industry linkages has been emphasized in development economics, especially in the theory of unbalanced growth (Hirschman, 1958; Jones, 1976), but has rarely been used or considered in strategic management 
research regarding diversification (c.f., Lemelin, 1982; Zhou, 2011). Combining insights that arise from the understanding of industrial linkages with knowledge that have been accumulated with the notion of relatedness may form a stronger foundation for future diversification research, especially regarding business groups.

\section{Organization of the Dissertation}

This chapter has provided a brief introduction to the remainder of the dissertation. Chapter II presents a critical review of studies and theories that are relevant for this dissertation. Chapter III examines diversification at the business group level and argues that group-level diversification should not be viewed in the same perspective that has been used in studies of firm diversification. This idea is tested empirically based on 30 South Korean major business groups' industry portfolio data from 1999 to 2008. Chapter IV focuses on business group member firms' diversification patterns to examine how business group characteristics may affect member firms' diversification choices. I extend the ideas developed in Chapter III to the member firm level to argue that business group member firms have incentives to pursue certain directions in their diversification choices under the influence of their respective business groups, which have distinct characteristics. I combine the data used in Chapter III with firm-level diversification and industry entry data to test the general idea. Chapter V discusses the overall implication of the findings, suggests future research directions, and concludes the dissertation. 


\section{CHAPTER II}

\section{LITERATURE REVIEW}

\section{Definition of Business Groups}

No single definition exists for the business group. Many different forms of business groups exist and operate in different countries and institutional contexts (Morck, 2010; Yiu, Lu, Bruton, \& Hoskisson, 2007).

Leff (1978: 663) proposes probably the earliest definition of a business group: “a multicompany firm which transacts in different markets but which does so under common entrepreneurial and financial control". Leff's definition treats a business group like one single integrated firm even though the group member firms are legally independent. Other definitions that downplay the independence of member firms of a business group largely follow his perspective on business groups (Chang \& Hong, 2000; Mahmood \& Mitchell, 2004). ${ }^{4}$

One of the most widely used academic definitions of business groups is Granovetter's (1995:95): “collections of firms bound together in some formal and/or informal ways, characterized by an 'intermediate' level of binding”. Granovetter's definition explicitly recognizes that even though there may be some degree of integration among the member firms of a business group, they are basically separate.

\footnotetext{
${ }^{4}$ Chang and Hong (2000: 429) define a business group as "a gathering of formally independent firms under the single common administrative and financial control of one family". Mahmood and Mitchell (2004: 1348) define business groups as "conglomerations of nominally independent firms that operate under common administrative and financial management and often are controlled by families". Their definitions largely focus on the role of the business group as a hierarchy, downplaying the legally independent nature of business group member firms as simply titular or nominal.
} 
Khanna and Yafeh (2007) offer a similar definition, but further clarify the characteristics of member firms: "legally independent firms, operating in multiple (often unrelated) industries, which are bound together by persistent formal (e.g., equity) and informal (e.g., family) ties". Additionally, Kock and Guillén (2001:78) define business groups as "loose constellations of firms spanning a wide variety of manufacturing and service industries held together by common ownership or informal control ties.”

In these definitions that focus on ties among business group member firms rather than the hierarchical administrative control, the existence of an entity that controls and guides all the member firms is not evident. To account for that, Colpan and Hikino (2010) distinguish network-type business groups, in which no single dominant entity exists, from hierarchy-type business groups, where a single entity is supposed to dominate strategic decision-making. Morck (2010) and Guillén (2010) suggest the existence of an entity that controls all the member firms as one of the main features of diversified business groups. Indeed, even though Japanese keiretsu may fall into the category of network-type business groups, this category has the potential danger of encompassing too wide a variety of economic relationships such as regional clusters and strategic alliances (Langlois, 2010).

Among hierarchy-type business groups, family-controlled ones are by far the most common and influential across countries (Langlois, 2010; Morck et al., 2005). Even though political considerations often support the formation and growth of business groups (Schneider, 2009), it is rare to see business groups directly controlled by a national government outside of China, where the government has fostered the formation 
of business groups (Keister, 1998) and used them to control strategic industries vital to the national economy (Yiu et al., 2005). This dissertation focuses on hierarchy-type business groups and acknowledges the existence of controlling shareholders, who are usually family members.

Some scholars include even Western-style conglomerates within the conceptual boundary of business groups (Altomonte \& Rungi, 2012). However, what really characterizes the business group is not control per se but rather the non-financial nature of control, which is based on the social solidarity often arising from kinship (Granovetter, 1995; Jones, Hesterly, \& Borgatti, 1997; Smångs, 2006). Including Western-style conglomerates in the definition may dilute the importance of this unique characteristic. This dissertation is based on the view that business groups are different from conglomerates.

There are numerous empirical studies of business groups as indicated by the number of published and unpublished studies on which a recent meta-analysis on business groups was based (Carney, Gedajlovic, Heugens, Van Essen, \& van Oosterhout, 2011). However, given the definition of business groups, it appears that too much attention has been paid to the member firm level rather than the group itself. Most empirical studies of business groups have been done at the member firm level; this is despite the complexity and heterogeneity of business groups arising from the fact that they are collections of firms, each of which is already a complex economic and social phenomenon. 
The economic implications of business groups have mostly been examined based solely on membership (Carney et al., 2011). A majority of prior studies of business groups examine the performance implications of business group membership at the firm level, trying to determine whether business group member firms outperform nonmember firms (e.g., Chang \& Choi, 1988; Ferris et al., 2002; Khanna, 2000; Khanna \& Palepu, 2000a, b). Scholars have also employed this approach in multi-country studies to determine whether weak institutions promote the economic success of business groups (e.g., Khanna \& Rivkin, 2001).

However, these research questions make the unlikely assumption that membership in any business group has a universal impact irrespective of each business group's unique characteristics and circumstances. Additionally, this approach ignores the possibility that business group member firms may develop characteristics and strategies that are different from those of non-member firms, which would make the comparison between the two groups difficult, if not impossible (Siegel \& Choudhury, 2012). Even though it is worthwhile to examine whether business group membership in general is positive or negative in terms of member firm performance, it may be arguably more important to see how different group-level characteristics may affect different member firms' characteristics and strategies.

\section{Theoretical Approaches to Business Groups}

Scholars have taken diverse theoretical approaches to study business groups (Yiu et al., 2007). Major theories employed include transaction cost theory (Khanna \& Rivkin, 2001), agency theory (Bertrand et al., 2002; Morck \& Yeung, 2003), resource- 
based theory (Kock \& Guillén, 2001; Tan \& Meyer, 2007), and network theory (Mahmood et al., 2013; Mahmood et al., 2011).

However, we still do not fully understand why business groups exist and how they function, evolve, and thrive to adapt to the ever changing external environment. Yiu et al. (2007) comment aptly that diverse theoretical perspectives may hinder, rather than contribute to, the further understanding of business groups. I argue that the underlying reason the applications of diverse theories have not led us to a better understanding of the business group is that these theories were developed for the firm rather than the business group and that scholars have not fully accounted for the differences between the two when trying to apply their theories.

A business group is made up of legally independent firms (Khanna \& Yafeh, 2007). Each of the member firms develops its own organizational structure and has a different mix of shareholders (Manikandan \& Ramachandran, 2014). From the perspective of minority shareholders, what counts is the performance and value of the member firm in which they hold the shares. Therefore, each member firm has an incentive to maximize its shareholder value in order to satisfy its shareholders unless the member firm is owned entirely by the controlling shareholder. Empirical studies on business groups that use the business group member firm as the unit of analysis implicitly make this assumption of profit maximization.

However, each member firm of a business group is also influenced by its controlling shareholders and the overall business group structure. In other words, firms that have their own boundaries are placed within yet another boundary and the business 
group to which they belong forms a special operating environment for the member firms. This is where confusion about business groups starts because some approximation has to be made in order for existing theories about the firm to be applied to the business group.

In the following subsections, I introduce some of the major theoretical perspectives that have been employed to explain business groups. What I argue is that it may not be appropriate to directly apply these perspectives to business groups because the perspectives have been developed for firm-level analysis and do not consider the market-like characteristics of the business group.

\section{Transaction cost theory}

Transaction cost theory was developed to explain the existence and scope of the firm (Coase, 1937). According to transaction cost theory, if the market were completely efficient, there would be no need for firms to coordinate and control economic activities within their boundaries. However, since certain activities incur more transaction costs than other activities, firms arise to handle such activities internally. It is argued that firms will continue to include or exclude activities within their boundaries, which will ultimately determine the scope of firms (Williamson, 1979).

Because transaction costs determine the scope of a business according to transaction cost theory, scholars trying to explain business groups based on the theory have emphasized differences in overall level of transaction costs across countries caused by 'institutional voids', that is, weak or missing institutions (Khanna \& Palepu, 2000b). According to this approach, the business group is a mechanism to cope with market failures that increase overall transaction costs of an economy in various areas such as 
product markets, capital markets, and labor markets (Khanna \& Palepu, 1997; Leff, 1978).

With this approach, the main empirical question becomes whether the organizational form of business group is economically efficient in a particular institutional environment. Scholars have approached the question by comparing the economic performance of business group member firms with that of independent firms, in countries with varying degrees of institutional deficiency (Khanna \& Palepu, 2000a; Khanna \& Rivkin, 2001). As transaction cost theory has been the most popular perspective on business groups (Yiu et al., 2007), most of previous empirical studies on business groups have been based on this approach.

However, despite the popularity of the perspective, transaction cost theory cannot directly account for the existence of business groups. According to the theory, if the overall level of transaction costs is high in an economy, more economic activities are supposed to be cheaper to carry out within the firm boundary than through the external market (Coase, 1937; Williamson, 1979, 1981). However, the ultimate consequence of high overall level of transaction costs in a country should be the potentially expanded scope of firms, not the birth and growth of business groups. Therefore, transaction cost theory does not directly explain why diversified business groups should be more prevalent than multidivisional enterprises in emerging markets where transaction costs are assumed to be higher than in advanced economies. Transaction cost theory does not consider the business group as an alternative option to the diversified firm. In other words, transaction cost theory may be able to answer the question, "Why do firms 
exist?", but it may not be able to answer Granovetter's (1995) question, "Why do business groups exist?"

Influenced by Leff's (1978) definition of the business group as a multi-company firm, some studies have explicitly regarded the business group as a single multidivisional firm to account for the existence of the controlling shareholders as the "control tower" (Chang \& Choi, 1988; Chang \& Hong, 2000). In fact, when scholars state that a business group is diversified, they implicitly assume that the hierarchy lies at the business group level rather than at the firm level. However, this approach overlooks the fact that each individual member firm is a legally independent firm with a different ownership structure and enjoys a substantial degree of autonomy (Kock \& Guillén, 2001). On the other hand, if transaction cost logic is applied to the firm level, it would be each individual member firm that chooses its own boundary, perhaps with some influence from and consideration for the overall business group structure. However, in this case, because the hierarchy is assumed to be at the level of each member firm, the business group's decision to add or maintain a legally independent member firm cannot be explained.

The direct application of transaction cost theory to the business group also results in confusion and inconsistencies in empirical studies of business groups. Previous studies have tested whether business group member firms are economically more efficient than stand-alone firms (Belenzon \& Berkovitz, 2010; Carney et al., 2011; Chakrabarti, Singh, \& Mahmood, 2007; Chang, 2006; Khanna, 2000; Khanna \& Rivkin, 2001). 
However, if the direct application of transaction cost theory to the level of business group is to be strictly followed, the comparison should be made between business groups and stand-alone firms, not between business group member firms and stand-alone firms. When business group member firms and stand-alone firms are compared, the only difference between the two types of firms becomes business group membership, which basically assumes that business groups are homogeneous in nature and a membership to any business group has an identical effect.

Given the structural complexity of business groups, it would be difficult for this assumption to hold. Even though the business group may not have a legal status, it has many characteristics that may potentially affect the way its member firms operate. This type of empirical test also goes against transaction cost theory in that business group member firms are assumed to autonomously and independently pursue their own financial goals, rather than being partially under the hierarchy and authority of their business groups where they may be tasked to achieve group-level goals.

Another issue with the transaction cost approach to business groups based on the concept of institutional voids is the ubiquity of business groups even in countries with advanced institutions (Belenzon \& Berkovitz, 2010; Belenzon, Patacconi, \& Zelner, 2012a; Langlois, 2010; Morck, Strangeland, \& Yeung, 1998). This fact makes it difficult to claim that the business group is only a coping mechanism for market failures arising from institutional voids. Outside of a few common-law countries such as the United States and the United Kingdom, business groups, especially family-controlled ones, are very common even in advanced economies (Belenzon et al., 2012a; La Porta et 
al., 1999; Morck et al., 1998). Therefore, linking the existence of the business group automatically to institutional voids and to the issue of transaction costs may not provide a universal theoretical explanation.

\section{Agency theory}

Agency theory (Jensen \& Meckling, 1976) has been used to account for problems that can arise from the separation of ownership from control in modern firms (Berle \& Means, 1932). However, the focus of scholars taking this approach to business groups is not on the classic agency issue between owners and managers, but rather on the possibility that controlling shareholders may pursue their own benefits through expropriation of the wealth of minority shareholders (Dharwadkar, George, \& Brandes, 2000; Khanna \& Rivkin, 2001; Yiu et al., 2007). In the case of family-controlled business groups, it is argued that managers of a member firm may strive to work for the controlling family rather than for shareholders in general (Morck \& Yeung, 2003).

Scholars argue that expropriation is more likely when the controlling owner uses "pyramiding" 5 to maximizing the owner's control while minimizing actual financial contributions (Bertrand et al., 2002; Claessens, Djankov, Fan, \& Lang, 2002; Claessens, Djankov, \& Lang, 2000).

As with transaction cost theory, agency theory was developed with an independent, autonomous firm in mind (Jensen \& Meckling, 1976). Because a business group is made up of multiple legally independent firms, scholars using agency theory

\footnotetext{
${ }^{5}$ Pyramiding means "owning a majority of the stock of one corporation which in turn holds a majority of the stock of another" (Claessens et al., 2000: 93).
} 
conceptually view the business group as a collection of agency relationships (Yiu et al., 2007). In empirical tests, however, most studies simply focus on each member firm and determine whether there is evidence of expropriation at the member firm level based on its ownership structure (e.g., Bae et al., 2002; Bertrand et al., 2002; Chang \& Hong, 2000; Claessens et al., 2002); this approach may not be able to capture how the complex structural characteristics of business groups and multiple ties among member firms affect each firm's business strategies.

For example, Bertrand et al. (2002) concluded that tunneling was widespread among Indian business groups after finding out that business group member firms profited less from positive industry shocks than stand-alone firms. However, as Siegel and Choudhury (2012) point out, what Bertrand et al. (2002) found that seemingly appears to be the consequence of tunneling may arise because business group member firms pursue more complex and costly recombinative activities than stand-alone firms. Siegel and Choudhury (2012) only consider mere membership to business groups, but their finding insinuates that the business group structure and relationships within it may lead its member firms to pursue strategies that are different from those of stand-alone firms (Manikandan \& Ramachandran, 2014).

Another point to consider about potential expropriation by the controlling shareholders is that expropriation may incur costs for them. Minority shareholders of a business group member firm, fully anticipating that there will be expropriation, may simply stop investing in the firm (Colpan \& Hikino, 2010; Masulis, Pham, \& Zein, 2011). If minority shareholders do not stop investing, it may be an indication that 
investing in the firm gives them benefits that at least compensate for the expropriation potential. ${ }^{6}$ One such benefit may come from the reputation that the business group has not mistreated minority shareholders (Gomes, 2000), which is actually consistent with the notion that business groups can compensate for missing or underdeveloped institutions (Khanna \& Palepu, 2000a). Another benefit, on which this dissertation focuses, may come from the firm's linkages with other member firms within the business group and value creation potential arising from those linkages. Investors may appreciate the fact that the business group member firm in which they invest benefits from the special market-like environment provided by the business group structure.

\section{Resource-based theory}

The central idea of resource-based theory is that firms are bundles of resources and capabilities (Penrose, 1959) and rare, valuable, inimitable, and non-substitutable resources and capabilities lead to a firm's competitive advantage (Barney, 1991; Wernerfelt, 1984). Scholars approaching business groups with resource-based theory tend to focus on group-level resources rather than resources at the member firm level.

Resource-based advantages of business groups have been discussed often in close connection with institutional voids (e.g., Guillén, 2000; Yiu et al., 2005). Ghemawat and Khanna (1998), for example, argue that institutional voids foster the formation of business groups by making "generalized" resources and capabilities

\footnotetext{
${ }^{6}$ Another possibility is that investors may simply not be able to find a better alternative in which to invest. However, the fact that business groups are flourishing in many developed countries and they are not losing relevance in countries that are experiencing improvements in terms of institutional environments indicates that this possibility cannot explain continued investor interest in business group member firms satisfactorily.
} 
valuable. Project-execution capabilities (Amsden \& Hikino, 1994), the capability for repeated industry entry (Guillén, 2000), and the capability to leverage contacts (Kock \& Guillén, 2001) may be examples of such resources. Guillén (2000) also argues that such generic capabilities may lose value over time as institutions improve and foreign trade and investment asymmetries between the emerging country and developed countries disappear.

However, trying to locate resource advantages solely at the level of the business group may obscure the role of each member firm, and overlook the question of how member firms obtain and develop their own resources and capabilities within the business group boundary (Mahmood et al., 2011). Like transaction cost theory and agency theory, resource-based theory was originally developed for independent and autonomous firms (Heugens \& Zyglidopoulos, 2008). Focusing only on group-level resources may miss the presence of firm-level resources and the potential that member firms may build resources and capabilities either by themselves or in concert with other member firms to improve their firm-level competitiveness.

Chang and Hong (2000) overcome some of these limitations by studying the firm-level performance implications of within-group resource sharing and business transactions, but they still do not provide an answer to the question of how business group member firms may collectively engage in the formation and integration of resources and capabilities. To reach a more complete understanding of the business group, I argue that we need to examine resources and capabilities on both business group level and firm level, rather than focusing on either level. To do that, we have to realize 
that the each of the two levels - business group level and member firm level - has distinct characteristics.

\section{Social network theory}

As Granovetter's (1995) influential definition of business groups indicates, business groups are rich in formal and informal linkages among member firms.

Therefore, some recent studies employ social network theory to study business groups.

Viewing business groups as networks and member firms as nodes, the studies use network-theoretic concepts such as centrality and tie density to explain firm-level or business group-level outcomes (Mahmood et al., 2013; Mahmood et al., 2011; Smångs, 2006).

Mahmood et al. (2011) regard a business group as an external source of R\&D capability acquisition for its member firms. They argue and find that a member firm's centrality in the intragroup buyer-supplier network contributes to the firm's R\&D capability. They further show that characteristics of other types of network ties, such as intragroup director and equity ties, either strengthen or weaken the main hypothesized relationship. This study, focusing on the level of member firms, regards the business group simply as existing outside the boundary of each member firm. On the other hand, Mahmood et al. (2013) use the business group as the unit of analysis to argue and find that the density of intragroup buyer-supplier ties has an inverted-U shaped relationship with group innovativeness.

The network theoretic approach can capture the overall structure of the business group and the position of each member firm nicely. However, it is the controlling 
shareholders that initially design member firms' embeddedness in the business group network. Treating a business group as a network and assuming that each node (member firm) is completely independent overlooks the fact that the controlling shareholders can design and structure the overall business group linkages.

\section{Diversification and Relatedness}

Why do firms diversify? It is one of the fundamental questions in the strategic management field (Rumelt, Schendel, \& Teece, 1991). Under the assumptions of neoclassical economics, the firm is simply a production function that specializes on a single type of product. When the market is perfect and so there are no frictional costs of transacting through the market, diversification may not be justifiable. Therefore, the widespread existence of firm diversification indicates that there is some degree of imperfection in the market (Hoskisson \& Hitt, 1990; Klein \& Lien, 2009). Indeed, if the assumption of competitive equilibrium held perfectly and managerial actions did not affect firm performance, the whole purpose of strategic management would be moot because the field seeks answers on how to gain sustainable competitive advantages through managerial actions. Therefore, any type of diversification - be it related or unrelated - may be thought of as an action to take advantage of or respond to market imperfections.

One of the most important factors that contribute to market imperfections, and thus to diversification, are firm resources (Barney, 1986, 1991; Chatterjee \& Wernerfelt, 1991; Penrose, 1959; Teece, 1982). Certain resources are difficult to trade on the market because of their indivisibility (Penrose, 1959) and social complexity (Coff, 1999; 
Jonsson \& Regnér, 2009). These problems may lead managers to take advantage of their excess resources in another, related business where the slack resources can be used either as substitutes or complements (Klein \& Lien, 2009). In this line of logic, operating in related businesses may yield synergies for the firm, causing performance to improve (Montgomery \& Wernerfelt, 1988; Palich et al., 2000; Rumelt, 1974).

Another important factor that causes market imperfection and thus diversification are transaction costs (Williamson, 1979). When the costs of organizing activities within the boundary of the firm are lower than the costs of transacting with external parties, it becomes more efficient for the firm to diversify into those activities. Because the level of transaction costs is substantially dependent upon the nature of resources and capabilities behind the business activities, it may be said that the two factors - resources and transaction costs - are intricately tied with each other in determining the scope of the firm (Argyres, 2011; Jacobides, 2008; Jacobides \& Winter, 2005).

Therefore, even though there are other potential antecedents of diversification such as government policy (Ravenscraft \& Scherer, 1987; Scherer, 1980), low performance (Fiegenbaum \& Thomas, 1988; Rumelt, 1974; Sanders \& Hambrick, 2007), and cash flow uncertainty (Hoskisson \& Hitt, 1988), resources and transaction costs may be considered as the two main drivers that determine the economic efficiency of diversification.

The implication of the combination of these two factors is that a diversification strategy based on the relatedness criterion may create value by conferring synergistic benefits on the firm (Chatterjee \& Wernerfelt, 1991; Montgomery \& Wernerfelt, 1988). 
Moreover, these benefits should continue until the costs of managing activities internally go over those of transacting with outside parties.

Unrelated diversification obviously violates the relatedness criterion. Therefore, it has been viewed negatively even though unrelated diversification has the potential for financial synergies (Amit \& Wernerfelt, 1990; Chatterjee, 1986) and there are some prominently successful conglomerates such as General Electric or Siemens. Unrelated diversification has often been regarded as a sign of top managers' self-interest seeking behavior (Amihud \& Lev, 1981; Jensen, 1986; Jensen \& Meckling, 1976).

Because it is hard to justify unrelated diversification based on pure efficiency considerations, scholars tend to link it to market failures and resulting high transaction costs that characterize underdeveloped countries (Khanna \& Palepu, 1997; Khanna \& Rivkin, 2001). In underdeveloped and emerging economies, unrelated diversification tends to take the form of the business group. This is the reason that business groups have often been regarded as prime examples of unrelated diversification even though they are fundamentally different from conglomerates.

In this dissertation, I argue that business group diversification is different from ordinary firm diversification in terms of its purpose. To show that it is the case, I emphasize the fact that industries have linkages with one another and some industries have more linkages than others. Business groups, as collections of firms, have a unique advantage in exploiting this inter-industry linkages compared with stand-alone firms. I argue that unlike stand-alone firms, business groups diversify to bridge such linkages than to obtain synergies from operating in related industries. 


\section{CHAPTER III}

\section{GROUP-LEVEL DIVERSIFICATION AND INTER-INDUSTRY LINKAGES}

\section{Introduction}

Business group level diversification represents the span of industries in which all the member firms of a business group engage. It is fundamentally related to the initial formation of business groups because the first decision of the controlling shareholders to diversify by starting a new firm instead of diversifying within the existing firm's boundary initiates a business group. Why would the controlling shareholders set up another firm to diversify rather than diversify within the existing firm?

For a stand-alone firm, an excessively high level of diversification is generally known to be negative for performance (Ansoff, 1987; Markides \& Williamson, 1996; Palich et al., 2000). Diversification makes it possible for the firm to utilize excess firmspecific assets (Markides, 1992; Penrose, 1959), gain economies of scope through sharing resources and activities (Markides \& Williamson, 1994), and use superior internal information to allocate resources among different lines of business more efficiently than the market (Markides, 1992). However, as the degree of relatedness goes down among different lines of business, such positive effects may deteriorate and various costs of management may begin to increase (Grant, Jammine, \& Thomas, 1988; Markides, 1992). As activities within a firm become too disparate, the purpose of the firm may become less coherent (Teece, Rumelt, Dosi, \& Winter, 1994) and social 
comparison costs among its employees may increase (Nickerson \& Zenger, 2008), eventually causing the firm's performance to deteriorate.

This line of logic has been directly applied to business groups even though business groups are not firms but collections of firms. The business group is often referred to as the quintessential form of unrelated diversification (Hoskisson et al., 2005; Khanna \& Rivkin, 2001; Kock \& Guillén, 2001), where each member firm is commonly assumed to represent a different line of business or strategic business unit (Chang \& Choi, 1988; Chang \& Hong, 2000; Ferris et al., 2002; Leff, 1978). The logic based on the relatedness criterion has been commonly used to discredit the business group as an inefficient organizational form that can only work in poor quality institutional environments. Scholars argue that business groups are diversified widely to compensate for and take advantage of institutional weaknesses (Khanna \& Palepu, 2000a, b). Some scholars propose that business groups will lose their purpose and increasingly refocus their business portfolios as institutional environments improve (Hoskisson et al., 2005). In this chapter, I argue that group-level diversification should not be evaluated based on the same criteria that apply to firm-level corporate diversification because business groups, as “hybrid” organizations (Granovetter, 1995; Williamson, 1991), are not equivalent to firms. Within the boundary of a business group, thanks to formal and/or informal ties, its member firms as independent legal entities can transact with one another without getting exposed to various exchange hazards (Granovetter, 1995; Luo \& Chung, 2005). Given this market-like function of the business group, the purpose of diversification pursued by the business group may be more to provide its member firms 
with strategic resources (by setting up a well-functioning market within its boundary) than to pursue synergies from operating in related industries as in the case of the firm.

To explore this possibility, I focus on the strategic importance of inter-industry linkages (Burt, Guilarte, Raider, \& Yasuda, 2002; Chenery \& Watanabe, 1958;

Hirschman, 1958; Lemelin, 1982; Rasmussen, 1956) for business groups. I argue that a business group is likely to enter an industry that is related to many other industries. Entering an industry that has an impact on multiple other industries may provide the group's member firms with rich and crucial linkages with the rest of the economy. The implication is that a business group may encourage its member firms to pursue related diversification by pursuing unrelated, but still strategic, diversification at the group level. Figure 2 graphically presents the three hypotheses that are presented in this chapter.

To empirically test these hypotheses, I analyze the diversification patterns of 30 major South Korean business groups from 1999 to 2008 using categorizations and data available in South Korean input-output tables prepared by the Bank of Korea. Inputoutput flows among 77 industries are used to determine the impact an industry has on the rest of the economy (Burt et al., 2002).

Prior research on diversification has mainly focused on the degree of diversification starting from a firm's primary industry based on the concept of relatedness (Hoskisson \& Hitt, 1990; Rumelt, 1974). This chapter extends the diversification literature by turning attention to the inherent linkages among various industries and the importance of multiple impacts an industry may have for other industries (Chang, 1999; Hirschman, 1958). Previous research on business groups tend 
to depict them as an organizational form that cannot function efficiently in the environment with strong and advanced institutions (Guillén, 2000; Hoskisson et al., 2005; Kock \& Guillén, 2001). Examining business groups' diversification patterns through the lens of inter-industry linkages may reveal that business groups are highly strategic in their diversification choices. Theoretically, it may indicate that business groups are less of an outcome of institutional voids, but more of a consequence of pursuits for critical resources and growth opportunities (Lamin, 2013; Manikandan \& Ramachandran, 2014). If it is the case, business groups will certainly not lose their relevance even after institutional environments in emerging markets and developing countries reach a similar level of quality to that of developed countries.

\section{Theory and Hypotheses}

\section{Nature of the business group}

The business group is characterized by an " intermediate' level of binding" (Granovetter, 1995:95). Even though there may be some degree of integration among the member firms of a business group with the presence of the controlling shareholders (Guillén, 2010; Morck, 2010), the member firms are legally independent (Khanna \& Yafeh, 2007) and typically enjoy a substantial degree of autonomy (Kock \& Guillén, 2001; Smångs, 2006). While some studies have treated business groups as if they were single multidivisional firms (Chang \& Choi, 1988; Chang \& Hong, 2000; Leff, 1978), business groups themselves are typically not legal entities. It is each member firm that is a legal entity. 
Business group member firms, with their own unique ownership and organizational structures, have their own corporate-level strategies. Each member firm has its own top management team and is overseen by its own board of directors, which may assess market opportunities independently from the controlling shareholders. Unlike a division in a multidivisional firm, an individual business group member firm has the autonomy to make its own decisions to pursue growth opportunities and directly face consequences of the decisions in the market (Manikandan \& Ramachandran, 2014). ${ }^{7}$ Indeed, some business group member firms are widely diversified themselves (Carney et al., 2011).

On the other hand, business group member firms are inevitably affected by the business group structure. When member firms transact with one another within the boundary of the business group, they may face few exchange hazards, if any, thanks to trust arising from formal and/or informal ties among them (Manikandan \& Ramachandran, 2014). However, when member firms transact with parties outside the business group, they may face the same degree of exchange hazards as stand-alone firms do. Therefore, business group member firms have strong economic incentives to take full advantage of their business group membership by transacting within the boundary of the business group.

\footnotetext{
${ }^{7}$ This will definitely be the case for publicly listed business group member firms. However, even if they are not publicly listed, business group member firms are different from a multidivisional firm's divisions, whose managers lack not only market-based incentives but also ultimate decision rights to pursue growth opportunities (Manikandan \& Ramachandran, 2014).
} 
In summary, the business group is a "hybrid" organization (Granovetter, 1995; Williamson, 1991). It is close to a firm in that the controlling shareholders form a hierarchy, while it is like a market in that member firms within the business group boundary enjoy transactional relationships that may be more efficient and flexible than those available outside the boundary. Therefore, treating the business group as if it were equivalent to the firm may discount this market-like role of the business group.

\section{Unrelated diversification and business groups}

It is generally agreed upon in the field of strategic management that related diversification leads to superior firm performance while unrelated diversification is harmful for firm performance (Palich et al., 2000; Rumelt, 1974; Wan et al., 2011). Extended to business groups, this consensus has been commonly used to discredit the business group as an inefficient organizational form that can only work in poor institutional environments because business groups are typically diversified widely into unrelated industries (Hoskisson et al., 2005; Khanna \& Rivkin, 2001; Kock \& Guillén, 2001).

Considering the market-like nature of the business group, however, opens up a new possibility. Given such market-like nature, the purpose of diversification that a business group pursues may be fundamentally different from that of a firm which represents a pure hierarchy. The controlling shareholders of a business group may focus on establishing a relevant and well-functioning group-wide market from which the group's member firms can benefit rather than try to control every aspect of the groupwide business portfolios. In turn, member firms' top managers may have a greater sense 
of control over their own resources than those of division managers of a single multidivisional firm (Manikandan \& Ramachandran, 2014); as a result, they may try to devise strategies that have the potential to maximize benefits of business group membership. Therefore, for a business group, unrelated diversification may not be a bad idea: a business group may engage in unrelated diversification to provide its member firms with a better special market with more critical resources so that its member firms need not diversify too far from their core activities.

Manikandan and Ramachandran (2014) argue and provide evidence that business group member firms enjoy greater opportunities to grow than stand-alone firms and these opportunities become even greater as the diversity of group-wide portfolio goes up. This evidence clearly indicates that the purpose of business group diversification may be different from that of firm diversification. Business groups may be concerned more about spurring growth of their member firms through the provision of critical resources than about obtaining synergies by choosing to pursue activities that are related with their core business.

The business group's market-making function has long been emphasized in connection with weak and underdeveloped institutions (e.g., Khanna \& Palepu, 1997; Leff, 1978). Scholars have argued that business groups can benefit from bridging and filling the missing advanced institutions (e.g., strong rule of law) that their own country environment lacks. Interestingly, this logic implicitly assumes that markets will always function efficiently when there are no institutional voids. In addition to the issue of determining what really constitutes "institutional voids", the assumption is clearly 
unrealistic given the fact that the whole justification of the existence of the firm comes from the realization that markets are not always efficient (Coase, 1937).

Manikandan and Ramachandran (2014), emphasizing the incomplete nature of markets (Denrell, Fang, \& Winter, 2003), argue that business groups have a unique strength in that they provide their member firms with privileged access to resources that may not be available through external strategic factor markets. When the incompleteness of external markets, irrespective of the degree of institutional developments, is considered, it becomes obvious that the business group form has the potential merit that is not exclusively based on institutional factors.

Furthermore, while a firm that engages in unrelated diversification may risk losing its corporate coherence (Teece et al., 1994), a business group that does the same thing may not suffer the same consequence because it is not a firm but a collection of firms, which can establish coherence collectively. Even though a business group may consist of multiple divergent lines of businesses, its member firms can stay coherent pursuing related diversification with their own legal identities, creating their own sets of stakeholders and governance mechanisms (Manikandan \& Ramachandran, 2014). Therefore, the criterion of relatedness that is highly relevant for a firm may not be so meaningful for the business group.

\section{Business group diversification and inter-industry linkages}

If the business group's purpose for diversification is to provide its member firms with a more attractive market with crucial resources, what type of industries will the business group target? 
Prior research on diversification does not provide an answer to this question because scholars have focused mainly on measuring the degree of relatedness among a firm's different business lines (Caves, Porter, \& Spence, 1980; Hoskisson, Hitt, Johnson, \& Moesel, 1993; Pehrsson, 2006; Rumelt, 1974). This approach may be called a firmcentric approach to relatedness because the approach focuses on potential synergistic effects arising from diversification within the firm. According to this way of measuring relatedness, no matter how relatedness is specifically measured, diversifying into an unrelated industry is just not desirable. Therefore, it does not provide any suggestion on how to pursue unrelated diversification as a business group. Given that the diversity of a business group may afford its member firms with unique resource sets to work with (Manikandan \& Ramachandran, 2014), it may be important for a business group to maximize the strategic impact of its diversification choices. In other words, at the business group level, what matters may be the strategic impact of an industry rather than potential synergies among activities within the group.

I therefore propose an industry-centric approach to relatedness for business group diversification. As Leontief's (1986) input-output model indicates, interdependencies exist among different industries. The idea that some industries are more important because they have more linkages with the rest of the economy has been commonly used in development economics and regional studies for many years. Hirschman (1958), for example, argues for a strategy of unbalanced growth that emphasizes promoting industries with strong linkages with other industries. For an individual firm that has to maintain coherence of its existence (Teece et al., 1994), inter-industry linkages may be 
just a matter of whether one industry is related to another industry that may be considered as a suitable entry target. Indeed, some scholars have tried to measure relatedness using inter-industry linkages (Lemelin, 1982; Villalonga, 2004; Zhou, 2011). For a business group, however, varying levels of inter-industry linkages among different industries may present important clues to the business group on what industries to enter to better support the overall economic efficiency of the entire group.

\section{Diversification choices of business groups}

Related industries. As has been discussed in Chapter II, many scholars consider a business group as essentially a firm with many different divisions that operate in unrelated businesses under a single hierarchy that is ultimately controlled by the controlling shareholders (Leff, 1978).

Teece et al. (1994) found U.S. manufacturing firms maintained their corporate coherence $^{8}$ even when they engaged in many different activities and concluded that firms typically expand by diversifying into related activities. Teece et al. suggested that firms that pursue unrelated diversification, because of low path-dependency and slow learning, would not be able to survive in a tight selection environment characterized by intense competition. Kogut and Zander (1996) propose that coherence is not just the outcome of path dependency and efficiency seeking but also the consequence of pursuit of social identity, without which cognitive dissonance and conflict arise among members. If business groups are regarded as firms with a single hierarchy, they cannot

\footnotetext{
${ }^{8}$ Teece et al. (1994: 2) explains the concept of coherence as follows: "Firms are coherent to the extent that their constituent businesses are related to one another."
} 
be immune from these issues. Therefore, when the controlling shareholders of a business group intend to expand into an additional industry, they will be likely to choose an industry to which the business group's existing operation is related.

The same conclusion can be made even when the approach that equates business groups to firms is not taken. A business group is a collection of its member firms at any given time. Therefore, the diversification of a business group is represented by the aggregated business portfolios of its member firms. Because business group member firms may follow the logic of diversification that pursues synergies (Rumelt, 1974), the overall diversification pattern of a business group will incorporate the relatedness criterion. Even if a business group is widely diversified into various industries, its member firms will still be operating in a narrower domain, specializing on activities that make them stay coherent (Teece et al., 1994). This basically means that if a business group is operating in a certain industry, it is more likely for the business group, as a collective entity, to enter another industry that is related with the industry. Therefore:

Hypothesis 1. A business group is more likely to enter an industry if the business group participates in a related industry.

Strategic industries. In fact, a business group is more than just a collection of member firms. Its member firms transact with one another in a special market-like environment characterized by rich social ties, enhanced trust, and lowered transaction costs (Granovetter, 1995; Luo \& Chung, 2005). Moreover, member firms may be able to get access to the various knowledge, know-how, and social connections of other firms 
within the boundary of the business group even without actually transacting with them thanks to the diminished potential of opportunism (Lamin, 2013).

The business group structure may represent a special marketplace where the member firm can evaluate the value of its own resources in relation to other member firms' resources, to which the firm may have a relatively unrestricted access thanks to the group's formal and informal ties. This may lead to growth opportunities that may not be obvious in markets outside the boundary of the business group due to the incomplete nature of strategic factor markets (Denrell et al., 2003; Manikandan \& Ramachandran, 2014). Given such potential benefits for the member firms, the controlling shareholders of a business group may strive to set up an overall business group portfolio that can provide the maximum exposure of strategic resources and capabilities to its member firms.

In the field of strategic management, relatedness has been mostly discussed regarding a firm's multiple activities. It is natural because the main concern of the field is the firm and how it can create competitive advantages through strategic actions (Nag, Hambrick, \& Chen, 2007; Schendel \& Hofer, 1979). When it comes to diversification, the consensus in the field is that a firm should be relatively focused and should pursue diversification when it can expect synergies arising from the relatedness of the new industry and the existing business portfolio of the firm (Montgomery \& Wernerfelt, 1988; Palich et al., 2000; Rumelt, 1974). For a business group, however, given its market-like characteristic, the main goal may be to create an environment in which its member firms can pursue such a path of diversification rather than to do it itself. 
For a business group, an industry that has linkages with multiple other industries may be especially attractive. This is where inter-industry linkages become relevant. First, by operating in such an industry, the business group will be able to maximize the impact of a diversifying move in terms of giving the member firms as much access and exposure to the entire economy as possible. This will help the member firms to get access to valuable information that can lead them to come up with alternative uses of and extensions to their own existing resources (Denrell et al., 2003). Linkages with multiple other industries may also provide the member firms with crucial market information without their needing to expand into areas unrelated to their existing portfolios (Lamin, 2013).

Second, entering an industry with multiple linkages can lower the member firms' dependency on external markets more effectively than entering an industry with limited linkages. Lowering external market dependency of the member firms can be particularly important for the controlling shareholders of the business group because the member firms will get exposed to the same transaction conditions with stand-alone firms outside the boundary of the business group (Pfeffer \& Salancik, 1978). Diversifying into industries that have impacts on multiple other industries may be a way to promoting advantageous within-group transactions among the member firms.

Therefore:

Hypothesis 2. The more linkages to other industries an industry has, the more likely it is for a business group to make a new entry into that industry. 
Interaction between relatedness and strategic value. The business group's rationale behind choosing to enter an industry that has linkages to multiple other industries is to provide its member firms with advantages in strategic resources. The value of such an industry may be reduced if a member of the business group is already participating in an industry that is related to the potential target industry. By operating in an adjacent industry, the business group may already be able to access critical market information that can be gained by entering the potential target industry (Lamin, 2013). On the flip side, the potential value of an industry with linkages to multiple other industries as an entry target will be enhanced if the business group is not currently operating in an industry related to it.

Moreover, the controlling shareholders of a business group may try to avoid interfering with the natural expansion of a member firm that operates in an adjacent industry by refraining from setting up a new firm or acquiring an existing firm in the specific strategic industry. Therefore, the presence of a related industry in a business group's portfolio may actually decrease the likelihood that the business group will enter the potential target industry with high strategic impact.

Hypothesis 3. The positive relationship between the number of industry linkages of an industry and a business group's likelihood of a new entry is weakened when the business group participates in an industry related to the target industry.

\section{Data and Methods}

I test the hypotheses above using the industry participation and entry data for 30 major South Korean business groups from 1998 to 2008 . The unit of analysis is the 
business group year for each industry. Because I use 77 industry categories and cover the 10 year period between 1999 and 2008, the total number of observations should be 23,100 . However, not all business groups in the sample are present throughout the period and there are some missing values. This reduces the sample size to 18,326 . Because this study explores the factors that may affect a business group's new industry entry decision, the cases where the business group is already present in a specific industry in the previous year are excluded. In the end, 14,344 observations are used for data analyses in this chapter.

\section{Business group data}

Studies on South Korean business groups have commonly focused on the top 30 business groups (e.g., Bae \& Jeong, 2007; Chang \& Hong, 2000, 2002). This practice originated from the fact that the Korean Fair Trade Commission (KFTC), until recently, identified and designated top 30 business groups annually based on the value of their total assets. Even though smaller business groups are organized in a similar way to that of larger groups, data on smaller business groups are more limited due to the fact that the business group is not a legal entity. While some business groups stay in the list of top 30 for the duration of the study period, others disappear from the list. The sample for this dissertation includes the 30 major business groups that were on the KFTC list for at least two consecutive years.

I used multiple sources to collect data. Most of the data were collected from the Data Analysis, Retrieval, and Transfer (DART) system, which is maintained by the Financial Supervisory Service (FSS) of the South Korean government. This system 
provides all the publicly available reports of all the listed firms and firms that are subject to external audits from 1998 on. I selected 2008 as the final year of the sample because the change of the format of annual reports made it difficult to clearly identify industries in which a firm operated in the report period. I supplemented the data from the DART with data from the KFTC, which provides more detailed specific information on major business groups.

\section{Industry data}

The industries are defined according to the 77 aggregated industry categories of the South Korean input-output tables, which are published by the Bank of Korea. I use aggregated industry categories for several reasons. First, the more detailed industry categories have changed over the years, while the aggregated categories stay the same. Therefore, by relying on the aggregated categories, a longer longitudinal dataset can be created and more timely sets of data can be used for statistical analyses. Given that the pace of environmental changes has accelerated because of globalization and technological innovations (D'Aveni, Dagnino, \& Smith, 2010), incorporating changes in inter-industry linkages may be profoundly important.

Second, the aggregated categories are more likely to fit the descriptions of operational portfolios of business group member firms than the more detailed categories (Burt et al., 2002). Because I depend on business group member firms' annual reports to find industries in which they are present and to which they make entries, larger numbers of categories could have resulted in more errors in collecting the data points. The Bank 
of Korea releases input-output tables every five years, so I use input-output tables from three different years $\left(1995,2000\right.$, and 2005) to cover the study period of $1999-2008 .^{9}$

Annual data on business groups' business portfolios and new entries are collected from their member firms' annual reports available on the DART system. To code each business group's diversification into each of the 77 industries, I first began by identifying all the member firms of the business group annually from 1998 to 2008 . Each of the member firms was checked for its major products and industry presence based on the firm's official reports filed in the DART system and whether the firm operated in each of the 77 industries was recorded. After the industry portfolios of all the firms of each business group were completely coded, I aggregated them into the business group industry portfolio by recording the industries that were covered by the business group's member firms.

\section{Variables}

Dependent variable. The dependent variable (ENTRY $i j t)$ is a dummy variable indicating whether business group $i$ entered industry $j$ in year $t$.

Independent variables. The strategic impact in terms of inter-industry linkages (IMPACT $\mathrm{IMt}_{j-1}$ ) measures the number of industries that are related to industry $j$ in year $\mathrm{t}-1$. Whether two industries are related is determined by the input-output 'use' tables using the one percent threshold (Lemelin, 1982; Zhou, 2011), that is two industries (X and Y)

\footnotetext{
${ }^{9}$ I used the 1995 input-output table for the years 1998, 1999, and 2000, the 2000 table for the years 2001 through 2005, and the 2005 table for the years 2006 through 2008. Using an input-output table that matches a given period of time may better reflect changes in industrial organization and technology than using just one year's input-output table as in Acemoglu, Johnson, \& Mitton (2009).
} 
are deemed related when one industry $(\mathrm{X})$ provides the other $(\mathrm{Y})$ with more than one percent of its (Y's) inputs. I assign a dummy variable value of 1 when two industries are related and 0 otherwise. I then count the number of related industries for each industry $j$ in year $t-1$; the higher the number is, the more linkages $j$ has with other industries.

Relatedness $\left(\right.$ RELATED $\left._{j t-1}\right)$ measures whether the business group operates in another industry that belongs to the broader categorization of a particular industry. The broader categorization scheme of the input-output tables consists of 28 industries.

Control variables. Several control variables were included in the empirical tests. Business group control variables included size, group-wide profit, age, business group scope (number of industries), and number of member firms.

In terms of size, a larger business group may have more resources to undertake more frequent diversification. I measured the size of a business group using either the logarithm of total assets or the logarithm of sales (which are highly correlated with each other with the correlation coefficient of 0.96 ) to minimize the potential for multicollinearity.

Group-wide profit may affect the likelihood of diversification either positively through the provision of free cash flow or negatively because of inertia. I use the logarithm of group-wide profit to make the distribution closer to normal because the distribution of the original variable shows an extreme level of kurtosis (17.18). ${ }^{10}$ The group-wide profit data were from the KFTC's database of large-scale business groups.

\footnotetext{
${ }^{10}$ I made each of the original values of the profitability variable positive before taking logarithm because it is impossible to take logarithm on a negative value.
} 
I also added business group age because younger business groups may be more active in diversification. Scholars have suggested that firms in early stages of development tend to be more aggressive in their diversification strategies (Jawahar \& McLaughlin, 2001; Sirmon, Hitt, Ireland, \& Gilbert, 2011) and it may be reasonable to apply the same logic to business groups.

The problem with some of these business group control variables is that the effect of size dominates the variables. Larger business groups tend to enjoy higher performance than smaller ones (Carney, 2004; Guillén, 2000; Khanna \& Yafeh, 2007). Moreover, it is rather obvious that a larger business group is likely to be in a higher number of industries and have more member firms than a smaller business group. The sample data show these relationships clearly. The correlation coefficient between business group total assets and profit is 0.86 . The correlation coefficient between business group total assets and business group scope is 0.67 , while the correlation coefficient between business group total assets and number of member firms is 0.71 . Therefore, it is problematic to use all these variables together in a same model.

To solve this problem, I measure profitability, scope and number of member firms independent of business group size by (1) running a regression model with each of the three variables as the dependent variable and business group size as the sole independent variable and (2) capturing the residuals of the model as the values of each variable. In this way, each of the variables captures unique variances that cannot be explained by business group size. For example, to calculate the size-independent business group scope, I first run a linear regression model with business group scope as 
the dependent variable and logged total assets as the sole independent variable. The residuals from this model become the values of the new size-independent scope variable. This new variable is not correlated with logged total assets, but still highly correlated with the original scope variable with the correlation coefficient of $0.74 .^{11}$

I also included industry controls: size and growth rate. I expected the bigger the industry, the more likely it would be for a business group to enter. I also expected the growth rate of an industry to positively affect the likelihood of a business group's entry. The size and growth rate of an industry were measured based on the total production value of that industry, based on data available from the Bank of Korea.

In addition, at the country level, I controlled for the annual growth rate of South Korean GDP to account for yearly fluctuation in national economic activities.

All of the independent variables and control variables are lagged one year. Table 2 provides descriptive statistics of the sample along with the brief description of each of the variables. Table 3 lists the pair-wise correlation coefficients between variables.

\section{Statistical methods}

For all of the hypotheses, I test the probability that a particular business group $i$ enters a particular industry $j$, where the business group did not previously operate in a particular year $t$. Therefore, logistic regression models were used to estimate the probabilities in question. To guard against potential heteroskedasticity problems, I used

\footnotetext{
${ }^{11}$ The new size-independent business group profitability variable and the size-independent number of member firms variable were also highly correlated with their raw counterparts with the correlation coefficients of 0.52 and 0.73 , respectively. The correlation coefficient for profitability is relatively low. This may indicate that the positive effect of business group size on business group profitability is quite strong (Carney et al., 2011).
} 
robust standard errors based on the Huber-White estimators (Huber, 1967; White, 1982). I also used standard errors clustered by each business group to compensate for potential bias arising from multiple data points per business group.

I used two alternative statistical models to deal with the uniqueness of the dataset. First, I used multilevel logistic regression to account for the fact that the dataset has a nested structure. The structure of the data can be seen as 77 industries that can be entered by each of the business groups. Second, I used a penalized likelihood method proposed by Firth (1993) to account for the fact that a new industry entry is a rare event. Among 14,344 observations in the sample, the number of new industry entries is only 123, which is approximately 0.85 percent of the total number of observations. Using Firth's logistic regression approach may help reduce the potential bias that can arise from the low prevalence of outcomes (Heinze \& Schemper, 2002).

I estimated all the models using STATA 12.1. For the estimation of the Firth logistic regression model, I used the Stata module developed by Coveney (2008).

\section{Results}

Table 4 presents the estimated effect of the control variables and independent variables on business group diversification choices. Columns (1) and (2) show the logistic regression model with only the control variables. Because total assets and sales for each business group are highly correlated, I only used total assets in column (1) and total sales in column (2). The estimated effect of the control variables did not show much difference. Thus, I only used total assets in the subsequent models. 
To examine the potential that the model may suffer from multicollinearity, I checked the variance inflation factors (VIFs) of the variables based on the linear regression form of the full specification. ${ }^{12}$ Strategic impact of the industry had the highest level of VIF (1.44) among the variables and the mean VIF was 1.20, which indicates that the models are not likely to suffer from multicollinearity. The correlation coefficients between any two variables are generally tame, as shown in Table 3, which also provides evidence that multicollinearity is not a serious concern. ${ }^{13}$

Column (1) shows that the only statistically significant control variable in explaining the likelihood of entry into an industry is the size of the industry. Obviously a large industry should attract and sustain a large number of firms. It is important to note that because the size of the industry has already been accounted for, we can be assured that the effect of independent variables has little to do with the industry size effect. The coefficients for total assets, profit, industry growth rate and GDP growth rate are positive but not statistically significant, while the coefficients for the business group's scope and number of member firms are negative and non-significant.

Column (3) displays the result when the relatedness variable is added to the controls-only model, and column (4) shows the result when the strategic impact variable

\footnotetext{
${ }^{12}$ According to Hitt et al. (2006), using ordinary least square models to calculate the VIF statistics provides more conservative test in terms of detecting potential multicollinearity.

${ }^{13}$ The highest correlation is between strategic impact and industry size $(r=0.47)$. To dispel any concern that the strategic impact of an industry may be predominantly determined by its size, I also calculated a size-independent measure of strategic impact based on the same method I used for the business group control variables and used the size-adjusted variable instead of the non-adjusted variable in the statistical models. The correlation coefficient between size-adjusted measure of strategic impact and non-adjusted measure was 0.88 , which indicates that an industry's strategic impact is not predominantly determined by its size. The overall results were nearly identical.
} 
is added to the model shown in column (3). The addition of each variable improves the previous model significantly as indicated by the significance of the log-likelihood test.

Column (5) presents the result for the fully specified logistic regression model including the two independent variables and the interaction term. I based the tests of my hypotheses on this fully specified model because the coefficients and p-values of this model are the most appropriate ones to interpret (Echambadi, Campbell, \& Agarwal, 2006; Edwards, 2009; Stone-Romero \& Liakhovitski, 2002).

In Hypothesis 1, I hypothesize that a business group is more likely to enter an industry if the business group participates in a related industry. In column (3), the coefficient for relatedness is positive and highly statistically significant $(\mathrm{p}<0.01)$, strongly supporting the hypothesis.

In Hypothesis 2, I hypothesize that a business group is more likely to enter an industry if it has linkages with multiple other industries. In column (3), the coefficient for impact, which represents the number of related industries in the focal industry, is also positive and highly statistically significant $(\mathrm{p}<0.01)$, providing solid support to Hypothesis 2.

In Hypothesis 3, I expected that the likelihood of entry into a strategic industry that has many linkages with other industries will be lower when the business group is already operating in a related industry. In column (3), the coefficient for the interaction term is negative as expected but not statistically significant $(\mathrm{p}=0.36)$. Therefore, Hypothesis 3 receives no support from the data. 
Column (6) shows the coefficients and p-values of the variables that were obtained from the multilevel logistic regression, taking into account the fact that the choices to enter 77 industries are nested within each business group. The outcome is not materially different from the results obtained from the logistic regression analysis. Column (7) presents the result of the Firth logistic regression analysis, which takes into account the fact that entries to new industries are rare events. The coefficients and pvalues in column (7) indicate that the results are consistent with that of the logistic regression model.

\section{Discussion}

The main purpose of this chapter was to argue and show the evidence that there needs to be an alternative explanation for business group diversification. Unlike a standalone firm that is under a unitary hierarchy, a business group member firm can be said to have two different hierarchies: the hierarchy of its own and that of the business group to which the firm belongs. For the member firm, the hierarchy of the business group means a special marketplace where the firm can transact and interact with other member firms of the business group in an environment that can be characterized by a high level of trust and a low potential for opportunism (Granovetter, 1995; Manikandan \& Ramachandran, 2014). Therefore, even though most prior studies on business groups have treated them as if they were firms, a business group has both the characteristics of a firm (in that the business group is a hierarchy) and those of a market (in that the business group provides resources and facilitates transactions among the members). 
Because a business group is a collection of firms, when the portfolios of a certain business group's member firms are aggregated, the business group's pattern of diversification will inherently follow that of ordinary firms. Hypothesis 1 captures this aspect of business group diversification and it receives strong support from the sample data of this study.

However, at the same time, a business group is much more than a collection of firms. The business group can protect its member firms from the harsh external environment by providing critical strategic resources that may not always be available through strategic factor markets because of their incompleteness (Denrell et al., 2003). The controlling shareholders may choose how to diversify the business group as a whole to provide resources that are critical for the growth of the member firms. Providing critical resources for the member firms may encourage them to focus on their own areas of core competencies instead of trying to diversify on their own to free themselves from resource dependency (Pfeffer \& Salancik, 1978).

To maximize the positive effects of group-level diversification both in terms of providing critical resources and establishing an environment that incentivize the member firms in a positive way, business groups may follow a criterion that is different from that of firms to decide what industries to enter. Hypothesis 2 suggests the strategic importance of an industry as a guiding principle for business group diversification. The fact that it was strongly supported by the data shows that business groups are indeed diversifying into industries with multiple linkages with other industries. This also indicates that even though business groups may look as if they diversified randomly into 
unrelated industries, business groups are in fact strategic, given the purpose of their diversification.

The statistical results also cast doubts about the explanation of business groups based on the notion of institutional voids. Scholars that advocate this perspective argue that business groups are able to bridge institutional voids by addressing the issue of market failures (Khanna \& Palepu, 1997). To be consistent with this view, business groups should engage in industries that are most likely to suffer from market failures. However, the results show that business group industry portfolios overlap a lot in industries that have multiple linkages with other industries. These industries are least likely to suffer from institutional voids.

To provide further evidence for that, I ran logistic regression models that estimate the likelihood of a business group's participation in each industry based on the same set of independent variables and controls that I used to estimate the likelihood of a new entry. Table 5 presents the results based on both a single year (1999) and all the years (1999-2008). It shows that the strategic impact of an industry is a very important factor in determining the likelihood of business groups' presence in the industry. The implication of this analysis is that certain "strategic" industries have higher concentrations of business groups than others. Therefore, these strategic industries are not likely to suffer much from market failures. Rather, the industries may help business group member firms overcome the incompleteness of strategic factor markets (Denrell et al., 2003) - which is the case not just for underdeveloped or emerging markets, but also for highly advanced economies. Therefore, automatically dismissing the business group 
form as a second-best option that can only work in certain underdeveloped and undesirable institutional settings may prevent us from seeing the value and potential of this unique organizational form. 


\section{CHAPTER IV}

\section{BUSINESS GROUP MEMBER FIRM DIVERSIFICATION CHOICES}

\section{Introduction}

Chapter III focused on the level of business groups. However, because a business group is made up of multiple legally independent firms (Khanna \& Yafeh, 2005), we need to consider both the group level and the firm level to grasp the business group's true economic implications. I argued in Chapter III that business groups diversify in order to provide their member firms with critical resources and to maximize the impact of a new entry, business groups choose industries with multiple linkages to other industries. In this chapter, I turn my attention to the member firm and examine the implications of a business group's diversification characteristics on its member firms.

According to Siegel and Choudhury (2012), business group member firms pursue more costly recombinative activities than non-member firms. One implication of this finding is that the business group structure and relationships within a business group affect member firms' strategies. Therefore, it is certainly possible that even among business group member firms, their strategic decisions and orientations may vary based on the overall business group structure.

This chapter explores that possibility by differentiating between business-group level diversification and firm-level diversification, conceptualizing several relevant business group-level characteristics, and examining their effects on member firms' diversification choices. Focusing only on the group-level phenomena misses the fact 
that each member firm within the group boundary may have a different organizational structure and strategic orientation. On the other hand, treating each member as an ordinary, stand-alone firm merely with a business group membership ignores the fact that the member firm may form strategies based on its unique position within the business group under the support and constraint of the business group's overarching structure.

This chapter draws attention to the understudied fact that the business group form may generate economic incentives for member firms (both carrots and sticks) by posing structural constraints while providing resources on which member firms can draw. Prior studies, even when they examine the internal mechanisms of business groups, tend to simply focus on how business group members can benefit from resources available within the group structure (Chang \& Hong, 2000; Mahmood et al., 2011). This chapter counterbalances it by considering the incentives arising from structural constraints as well as resource endowments. By highlighting economic incentives within the business group, I suggest that the business group as an organizational form could be seen as an organizational innovation set up to satisfy the diverse and often conflicting needs of the controlling shareholders and other shareholders. Thus, I argue that the business group could and should be viewed through a positive lens rather than in the "dark side" perspective that regards the business group as an organizational form that can only keep its relevance and advantage by bridging institutional deficiencies and exclusively benefit the controlling family at the expense of minority shareholders. 


\section{Business Group Characteristics}

\section{Formation and growth of business groups}

Pursuing unrelated diversification by setting up a new independent legal entity within the boundary of the business group can be a way to avoid some of the potential negative effects of unrelated diversification. The new firm will have its own management and organizational structure, which will at least lessen the coordinating costs that unrelated diversification would incur if it were undertaken within an existing firm. Top management of the new firm will not have to worry about other lines of business within the business group (c.f., Grant et al., 1988) while having access to critical strategic resources through the business group network (Manikandan \& Ramachandran, 2014).

Moreover, because the new firm is an independent legal entity, it will have relatively little constraint in terms of its own market exploration and pursuit of growth opportunities compared with a division within a firm. Because the expansion of scope is not occurring within the firm but across firms, envies and social comparisons within the firm will be checked (Nickerson \& Zenger, 2008). The controlling shareholders can also finance the new firm by devising an appropriate ownership structure for the level of risk. The new firm will have its own set of shareholders and stakeholders, which will make the firm's goals and objectives clearer and more coherent compared with the case of within-firm diversification (Teece et al., 1994).

Furthermore, it should be noted that if a substantial buyer-supplier relationship exists or is formed for the new firm and any existing firm within the group, the new firm 
will enjoy a solid footing in the marketplace even from the beginning. A pair of seemingly unrelated industries may generate a substantial amount of buyer-supplier transactions. The Chapter I opening vignette about the LG group shows this clearly. The LG group started as a cosmetics business and expanded by sequentially establishing businesses that are linked by buyer-supplier relationships. ${ }^{14}$ Transactions arising from such relationships will not be recorded as sales and only become the matter of transfer pricing within a firm, but those transactions will be recognized and recorded as sales between two legally independent firms within the same business group because the business group itself is not a legal entity and the two businesses within the group are considered independent legal entities.

Because of the various factors discussed above, the same degree of unrelated diversification may have materially different implications depending on whether it occurs at the level of a single firm or at the level of a business group. This may be part of the reason that business groups usually start a new firm (or acquire an existing firm) when they pursue unrelated diversification (Chang \& Choi, 1988). As examined in Chapter III, the purpose of a business group's diversification is more to provide its member firms with critical resources than to achieve synergies through scope economies. Therefore, for the business group's controlling shareholders, whether each member firm engages in an industry unrelated to one another may be less important than

\footnotetext{
${ }^{14}$ Scholars regarding the business group as a coping mechanism for institutional weaknesses may argue that this process of diversification reflects the underdevelopment of intermediate product markets (e.g., Khanna \& Palepu, 2000). However, institutions alone cannot explain why diversification leads to the formation of a business group made up of multiple legally independent firms rather than a single multidivisional firm (Manikandan \& Ramachandran, 2014).
} 
whether each member has a transactional relationship with one another. The transactional relationships are beneficial not just in terms of recorded sales, but also in terms of increased potential for firm-level capability development and group-level innovation (Mahmood et al., 2013; Mahmood et al., 2011).

\section{Diversification characteristics of business groups}

As a business group grows through both the diversification of existing member firms and creation or addition of new member firms, its structure becomes more complex and distinct structural characteristics may become more evident. Because a business group is a collection of firms, each group-level characteristic may be thought of as an aggregation of member firms' characteristics. On the other hand, as the number of member firms increases, it is likely that each of them will develop its own unique characteristics, thereby increasing the degree of variations among member firms of the business group. Because a business group member is placed within the business group boundary, the firm will be affected by the structural characteristics of the business group. However, this effect will be dependent upon the firm's own unique characteristics. Moreover, each firm's unique characteristics will have implications for the relationships among member firms within the business group as well.

Size. Growth of a business group obviously leads to its bigger size, whether it is measured by the number of total employees, assets or sales. The size of a business group means the combined size of all the member firms. This is a straightforward extension of numerous firm-level studies (e.g., Fong, Misangyi, \& Tosi, 2009; Ito \& Pucik, 1993; Leiblein \& Madsen, 2009). However, because this group-level construct 
represents an aggregation, it does not capture how a business group grows - whether through the growth of existing member firms or through additions of new member firms - but only how large the member firms are collectively.

In general, scholars propose that larger business groups can benefit from factors such as economies of scale (Khanna \& Palepu, 2000b), higher reputation in the marketplace (Morck et al., 2005), and political clout (Carney, 2005). Therefore, the larger the size of a business group, the more group-level resources into which its member firms may be able to tap (Chang \& Hong, 2000; Guillén, 2000; Khanna \& Yafeh, 2007).

However, the aggregative nature of group-level size belies firm-level variations. Business group member firms vary in size, often dramatically. The fact that a firm is a member of a business group of a certain size may have a different implication based on the firm's own size. Therefore, there is a need to consider size on both levels - group level and firm level - in trying to gauge the implication of business group membership.

Diversity and density. In this chapter, diversity captures how widely diversified a business group is (e.g., Chang \& Singh, 2000; Lee, Peng, \& Lee, 2008). Diversity is determined by the aggregation of the group member firms' diversification profiles. Because diversity is a group-level construct, it does not capture how widely diversified each business group member is. When each member of a business group specializes in a different business domain, group-level diversity may be high while member firms' degrees of diversification are low. On the other hand, it is possible that some member 
firms are widely diversified while others are relatively specialized at the same grouplevel diversity.

Density captures how close to each other member firms are in terms of their business domains. My approach to density is based on the organizational ecology perspective (Hannan \& Freeman, 1977) rather than how dense intragroup ties are as in the studies based on the social network theory (e.g., Mahmood et al., 2013).

Diversity and density are related concepts, but they capture different group-level implications of member firms' diversification moves. At a given level of group-level diversity, the more firms there are within the boundary of the business group, the higher the density will be. For example, when a member of a business group diversifies into an industry that has already been entered by another member, the degree of group-level diversity will not change because the entry will not expand the business group's span of industries. The same consequence would result from the addition of a new member that operates in the same industry. However, the density within the business group will increase because there is now more activities within the same group-wide span of industries. On the other hand, when a business group member diversifies into an industry that is new to the business group, the degree of group-level diversity will increase but that of density will hardly be affected.

One important implication of density is that as a business group's density increases, some overlaps in domain may arise among member firms. Prior studies on 
business groups do not discuss this possibility explicitly. ${ }^{15}$ Choi and Cowing (2002) note that profitable business groups in South Korea tend to expand within their existing domains rather than enter new markets, but their study is at the group level, so potential interactions among member firms that may result in a business group's expansion within its existing domain are not discussed. In fact, if business groups are studied only at one level, either the group or the firm level, it is inevitable that the relationships among group member firms are lost in translation. Additionally, even if both levels are taken into account, the possibility of domain overlaps may be discounted if member firms are regarded as strategic business units (SBUs) rather than as mostly independent and selfsufficient firms (e.g., Chang \& Hong, 2000). However, domain overlaps do arise in reality and may have significant strategic implications in terms of relationships among member firms and firm- and group-level efficiency.

This possibility is particularly salient when technological innovations lead to the convergence of several industries. For example, Cheil Industries, a member firm of Samsung Group, traditionally engaged in the production of textiles and apparels, but started electronic materials and parts business in 1998 to take advantage of the convergence of the electronics and chemical industries and to support Samsung Group's thriving electronics business. If the group's electronics business were controlled by one hierarchy - i.e., Samsung Electronics, it might be overexerting for the firm to pursue

\footnotetext{
${ }^{15}$ This could possibly be the consequence of implicitly equating business groups to multidivisional firms. For a multidivisional firm, with a unitary hierarchy, it would be hard to justify multiple divisions engaging in similar activities because of coordination challenges (Zhou, 2011). However, within a business group, which has multiple hierarchies (firms) in its boundary, each hierarchy can choose what activities to pursue more or less autonomously and the issue of coordination may be alleviated because of the market-like nature of the business group (Manikandan \& Ramachandran, 2014).
} 
potential opportunities arising from the convergence of multiple industries. However, even though Samsung Electronics is the central firm in Samsung Group's electronics business, there are many other firms that support and reinforce it: Samsung ElectroMechanics, Samsung SDI, Samsung Techwin, and Cheil Industries among others (Lee \& He, 2009). Because these firms stay distinct with their own strategic approaches and directions while supporting the overall group's business, their overlapping domains lead to cooperation and learning rather than competition and conflicts.

Interdependence. The case of business groups clearly demonstrates that the fact that a firm is legally independent may not necessarily mean it will only exist as an isolated and atomized entity (Granovetter, 1995; Heugens \& Zyglidopoulos, 2008). Describing a business group simply as a portfolio or collection of firms under a common ownership ignores the various interactions among member firms. In this chapter, interdependence captures how actively member firms of a business group transact with one another (Jones \& Hill, 1988; White, Hoskisson, Yiu, \& Bruton, 2008). When member firms of a business group do not transact very much with one another, they may be less dependent on the business group. A higher level of intragroup transactions provides evidence that more and tighter linkages exist among member firms (Mahmood et al., 2013), which lead to greater interdependence. I view transactional relationships within the group as also representing flows of information and knowledge as well as physical products and services (Child \& McGrath, 2001).

The controlling shareholders of a business group may intentionally set the level of transactional relatedness among member firms so as to form a strong, group-wide 
value chain (Porter, 1995). Doing so may give each member firm a unique position within the business group where the firm can pursue its own performance goals as well as contribute to the group as a whole. Therefore, on the firm level, each member firm's intragroup transactions will vary in terms of both size and direction (Chang \& Hong, 2000). While some member firms will engage in intragroup transactions extensively, others may mostly transact with outside parties. Some member firms may predominantly sell to other member firms, while others mainly purchase from other member firms.

In the following section, I use these diversification characteristics of business groups to develop hypotheses about diversification choices of member firms. I argue that the business group constrains member firms' choices as well as provides member firms with resources necessary for new market entries. Figure 3 graphically presents the overall model proposed in this chapter.

\section{Group Member Firms' Diversification Choices}

The diversification choices of member firms may be more straightforward to understand than group-level diversification because extant theories of diversification such as transaction cost theory and resource-based theory can be directly applied to firmlevel diversification (Hoskisson \& Hitt, 1990; Mahoney \& Pandian, 1992; Wan et al., 2011). Transaction cost theory explains diversification based on market imperfections (Coase, 1937; Williamson, 1971). Certain activities may be more economical to perform within the boundary of a firm if they are prone to suffer from exchange hazards, so the firm will decide to diversify into the activities. On the other hand, resource-based theory 
suggests that diversification is a way to leverage and further develop firm-specific resources and capabilities (Argyres, 1996; Penrose, 1959; Silverman, 1999).

For a member firm in a business group, in addition to firm-specific factors, the structural characteristics of the business group to which the firm belongs may also affect the member firm's level and nature of diversification. In other words, a member firm may have to consider the appropriateness of its diversification choices given such factors as resources available within the business group structure, the other member firms' diversification profiles, and its position within the overall business group structure.

The controlling shareholders may potentially interfere in the member's diversification decisions, but such interference may be unnecessary and costly when structural constraints are already in place. It may be unnecessary because the business group structure may provide the member's top managers with clear economic incentives to make the most of its circumstances, mitigating the potential for agency problems. It may be also costly because frequent interferences from the controlling shareholders may discourage member firm top managers from utilizing their unique insights and knowledge (Cohen \& Levinthal, 1990; Hayek, 1945).

Chang and Choi's (1988) observation that South Korean business group member firms mostly pursue related diversification may support this logic even though their arguments are based on the assumption that business group member firms are like internal divisions of a multidivisional firm. The observation may indicate that the business group member firms are conscious of the fact that they are within the 
organizational structure larger than themselves and they do not have to diversify into unrelated areas that are already covered by the overall business group structure.

\section{Business group size and firm diversification}

According to resource-based theory, a firm needs resources to diversify and the availability, quality and management of its firm-specific resources constrain the firm's diversification choices (Chatterjee \& Wernerfelt, 1991; Hoskisson \& Hitt, 1990; Wernerfelt, 1984). However, business group member firms, unlike stand-alone firms, can also tap into group-wide resources in addition to their own firm-specific resources when they decide to diversify into new industries.

Even though the resource-based theory was originally developed for completely independent and autonomous firms (Heugens \& Zyglidopoulos, 2008), most scholars approaching business groups using resource-based theory have focused on group-level resources rather than firm-level resources. This approach reflects the view that institutional weaknesses foster the formation of business groups by making 'generalized' resources and capabilities valuable (Ghemawat \& Khanna, 1998; Guillén, 2000; Yiu et al., 2005). In addition to such generalized group-level resources, the business group structure may promote cooperative behaviors based on mutual trust, giving member firms access to various resources residing within other member firms' boundaries (Chang \& Hong, 2000; Kim \& Hoskisson, 1996). The size of a business group may signify the size of the knowledge and resource repository that a member can draw on to make a new industry entry more feasible. Therefore, a member firm in a large business 
group will be more likely to diversify into a new industry than a member of a small business group.

Hypothesis 4a. The larger the size of the business group, the more likely is a member firm to enter an industry new to the firm.

The size of a business group, however, may have a different impact on each member firm based on its own size relative to that of other member firms. If one member firm of a business group is much larger than the other member firms, the dominant member firm may not enjoy a group-wide resource pool much bigger than its own even if the business group itself is large. On the other hand, the other member firms may benefit significantly more from having a large member within the business group. ${ }^{16}$ A business group is essentially a social network privately owned by the controlling shareholders (Chang, 1999). In an ordinary network structure, poorly embedded firms often pay hefty prices to build ties with highly embedded firms (Ahuja, Polidoro, \& Mitchell, 2009). A small firm in a large business group, just by being its member firm, is automatically embedded in a network, which allows the firm to access a resource pool much larger than its own. Therefore, the effect of group size will be larger for smaller member firms than for larger ones.

Therefore,

Hypothesis $\mathbf{4 b}$. The relative size of a business group member moderates the positive relationship between the size of a business group and the member's new

\footnotetext{
${ }^{16}$ A similar logic can be found in the international trade literature regarding the size of countries in the context of regional free trade agreement (Alesina, Spolaore, \& Wacziarg, 2005).
} 
industry entry such that the larger the member's size, the weaker is the relationship.

\section{Business group diversity and member firm diversification}

As the diversity of industries represented in the business group increases, member firms will be able to access an increasingly more diverse sets of tangible and intangible resources through intragroup factor markets (Claessens, Fan, \& Lang, 2006). For example, according to Lamin (2013), Indian information services firms that are business group member firms can serve more diverse industries and markets than standalone firms by tapping into the group-wide knowledge and social capital. She finds that this role of the business group as an information source becomes more substantial as the group-level diversification increases. In general, this implies that business group member firms will be able to focus on their core activities and capabilities without worrying about building resources extraneous to them.

Moreover, mutual trust among member firms within the business group may lessen the need to seek for economies of scale from internalizing transactions through vertical integration (Williamson, 1991). A business group member firm may suffer less from high transaction costs than a stand-alone firm in the same situation thanks to trust and shared values with other member firms within the group. Therefore, as the diversity of a business group increases, a member firm will be less likely to enter a new industry.

Hypothesis 5. The more diversified is a business group, the less likely it is for a member firm to enter an industry new to the firm. 


\section{Related diversification and intensifying density}

Perhaps the more important issue regarding a business group member firm's diversification than the likelihood of diversification in general would be whether the firm is likely to pursue related diversification or unrelated diversification.

Risk reduction based on portfolio theory is regarded as a major advantage of unrelated diversification (Kim, Hwang, \& Burgers, 1989). Diversifying into an unrelated industry may be tempting to the firm's managers because it may be able to maintain relatively stable performance should one of its industry domains suffer from industry-specific circumstances; unrelated diversification would decrease the firm's bankruptcy risk and the managers' employment risk (Amihud \& Lev, 1981). “Not having all one's eggs in one basket" as a motive for unrelated diversification is regarded as one of the most important agency problems for the corporate governance structure to deal with (Amihud \& Lev, 1999; Hoskisson \& Hitt, 1990; Martin \& Sayrak, 2003; Ramanujam \& Varadarajan, 1989).

However, for top managers of a business group member firm, it may be more difficult to justify an entry into an industry that is not closely related to the firm's existing industry portfolio especially when the business group is of a substantial size, because ample group-level resources may provide the firm with a buffer against shortterm jolts (Dewaelheyns \& Van Hulle, 2006). Moreover, the employment risk of managers of business group member firms may be less sensitive to industry-specific shocks than that of managers of stand-alone firms because the controlling shareholders may regard a member firm's contribution to the entire group more important than its 
short-term fluctuations in performance (Kato, Kim, \& Lee, 2007). ${ }^{17}$ Therefore, the increasing resource support coming from the size of the business group is likely to result in a member firm's entries into related industries rather than unrelated ones.

The diversity of a business group's industry portfolio will also help prevent managers of a member firm from diversifying into an industry unrelated to the firm's own industry portfolio because the coinsurance effect (Berger \& Ofek, 1995) that unrelated diversification is intended to accomplish may already be available through the business group structure. As the diversity of a business group increases, the risk reduction effect based on portfolio theory will become more salient at the group level. Therefore, it will be more difficult for top managers of a member firm to convince the controlling shareholders about a need for unrelated diversification of its own.

As the need to consider various diversification options decreases because of the presence of other member firms within the business group, a substantial amount of managerial cognitive resources of the member firm may be freed up (Aghion \& Tirole, 1995; Mahnke, Venzin, \& Zahra, 2007; Schwenk, 1984). Specializing in certain activities while giving up others may result in significant cost savings for each member firm (Gupta, Smith, \& Shalley, 2006; Miller, Zhao, \& Calantone, 2006). At the same time, by being a member of the group, the firm may be able to minimize the degree of

\footnotetext{
${ }^{17}$ Campbell and Keys (2002) found no relationship between firm performance and top executive turnover for top executives of top five business groups in South Korea based on data from 1992 to 1997. Kato, Kim, and Lee (2007), based on data from 1998 to 2001, showed executive pay was not sensitive to firm performance for top executives of firms belonging to top 30 business groups. These authors blame weak corporate governance for their findings, but it may be possible that the nature of group structure contributed to the findings. Dewaelheyns and Van Hulle's (2006) finding that member firms belonging to the business group's core business is more strongly supported than others insinuates the importance of considering the overall group structure as well as individual firms.
} 
hazards accompanying outsourcing (Dyer \& Chu, 2010). Therefore, the firm will be able to devote more of its firm-specific resources into further development and innovation in its existing industry portfolio. As this leads to cost savings and allows new resource and capability development, the firm will be able to form a strong resource base to diversify into closely related industries (Chatterjee \& Wernerfelt, 1991). Therefore, business group member firms are likely to diversify into an industry that is closely related to its existing industry portfolio.

\section{Hypothesis 6a. A business group member firm is more likely to enter a new} industry that is related to the firm's existing industry portfolio.

The fact that there are two different levels of diversification in the business group structure - firm and group - opens up another diversification possibility to a business group member: entering an industry in which other member firms are already operating not for competition, but for cooperation.

A business group member firm may have preferential access to distinct information, knowledge, and capabilities of other member firms of the business group (Manikandan \& Ramachandran, 2014). The firm will be able to understand and evaluate its own resources and capabilities in connection with those that are available through the business group structure, which may help the firm identify strategic opportunities that are hidden due to the incompleteness of strategic factor markets (Denrell et al., 2003). When the firm understands the connection between its own resource portfolio and an industry in which another member firm of the same business group engages, the firm will have an incentive to enter the industry to pursue the identified strategic opportunity. 
Mutual trust among business group member firms may enable them to share knowledge and information accumulated within their own boundary more freely with other member firms because the usual tension between knowledge sharing and protection (Kale \& Singh, 2009; Li, Eden, Hitt, \& Ireland, 2008; Zhao, 2006) may be minimized among member firms of a same business group. In other words, the business group form may be an ideal structure to govern alliance relationships among member firms. In normal situation, when alliance relationships become more complicated as in the case of multilateral research and development $(R \& D)$ alliances, more rigid governance structures based on equity are commonly utilized (Li, Eden, Hitt, Ireland, \& Garrett, 2012). A business group may be able to handle the governance of complex relationships of multiple multilateral alliances without rigid structures, promoting the intragroup development and sharing of new knowledge and knowhow. Therefore, a business in which other member firms are already operating may be an attractive entry target for a business group member firm.

Over time, this will lead to an increasing level of density, decreasing the distance among the member firms in terms of their business domains within the business group boundary. One important implication of the deepening density of a business group is that it may alleviate a serious coordination issue that is faced by stand-alone firms when they pursue related diversification. The pursuit of synergy arising from related diversification may be limited by costs of coordinating complex interdependencies within a single firm (Rawley, 2010; Zhou, 2011). The structure of business groups may provide an ideal environment for managing such interdependencies to member firms by 
engaging multiple firms in an industry and making sure that they stay cooperative to yield synergies while minimizing coordination costs.

Hypothesis $\mathbf{6}$. A business group member firm is more likely to enter a new industry in which other member firms already operate.

\section{Interdependence}

Transactions within the business group boundary may provide member firms with more direct benefits than mere membership or potential access to group-wide resources (Chang \& Hong, 2000).

From the perspective of transaction cost theory, a business group member is in an interesting hybrid position (Williamson, 1991). When the member firm transacts with other member firms within the group, the firm faces few exchange hazards, if any, thanks to formal and/or informal ties among them (Granovetter, 1995). However, when the affiliate transacts with parties outside the group, the affiliate may face the same level of exchange hazards as ordinary firms do.

The existence of intragroup transactions indicates that member firms are tapping into strategic factor markets inside the business group and providing intermediate goods and services to other member firms (Chang \& Hong, 2000). Member firms will be able to save transaction costs substantially thanks to mutual trust formed within the business group (Williamson, 1991). Therefore, the more they depend on other member firms for intermediate goods or services, the more they may be able to focus on matters other than transactional hazards. 
In essence, when interdependence among members of a business group is high, members may have less need to diversify widely to gain access to a new source of knowledge or resources because they will get access to market information and knowledge that would be normally kept within their transaction partners in the case of market transactions (Adler, 2001). Moreover, a stronger overall interdependence among business group members may make it more important for a member firm to consider the circumstances of other members (Granovetter, 1995; Heugens \& Zyglidopoulos, 2008). This may make a firm think twice before deciding to enter a new business.

Hypothesis 7. The higher the overall level of transactions within a business group, the less likely is a member firm to enter an industry new to the firm.

\section{Data and Methods}

I test the hypotheses in this chapter using the industry participation and entry data of listed non-financial member firms of 30 major South Korean business groups from 1998 to 2008. The unit of analysis is firm year for each industry. The sample used in this chapter includes 108 business group member firms. If all these firms are present throughout the study period, the number of observation would be 83,160 because there are 77 industry categories and the data cover a 10-year span. However, firms each previous year are already operating in some industries, which are excluded from the analyses. Additionally, some firms are present in only certain years in the sample and there are some missing data. In the end, the number of observations used in the main data analyses in this chapter is 59,723 . The description of business group data and 
industry data that are used in this chapter and the sources of the data are available in the previous chapter.

I used only publicly listed business group member firms in my analyses because they fit the purpose of this dissertation. First, the theoretical development of this dissertation is based on the assumption that the business group controlling shareholders do not have to control every aspect of every business in which the business group engages and that business group member firms are encouraged to exercise a substantial degree of autonomy. For firms that are privately owned by the controlling shareholders, this assumption may not hold. The strategic decisions of privately-owned member firms may reflect the controlling shareholders' intentions rather than the firms' adaptation to the business group environment.

Second, the degree of a firm's diversification (whether the diversification is related or unrelated) has often been scrutinized out of the concern for agency issues (Amihud \& Lev, 1981; Jensen \& Meckling, 1976). Given that the primary concern for the business group form arises because of the potential that the controlling shareholders may show opportunistic behaviors that may sacrifice the interest of minority shareholders, privately-owned business group member firms are not very relevant targets to focus on in terms of corporate governance. Indeed, in the field of finance, a business group is typically defined as "two or more listed firms under a common controlling shareholder" (Morck, 2010: 603). 


\section{Variables}

Dependent variable. Entry $\left(\mathrm{ENTRY}_{i j t}\right)$ is a dummy variable indicating whether firm $i$ entered industry $j$ in year $t$. Annual data on firms' business portfolios and new entries were collected from the firms' annual reports available on the DART system.

Independent variables. The core independent variable to test Hypothesis $4 \mathrm{a}$ and Hypothesis $4 \mathrm{~b}$ is business group size. The size of a business group is measured as the logarithm of business group total assets. ${ }^{18}$ For the test of Hypothesis $4 b$, I use the logarithm of each member firm's total assets as the proxy for firm size and add an interaction term between business group size and member firm size.

Hypothesis 5 tests whether the diversity of a business group's industry portfolio affects its member firms' diversification pattern. The diversity is measured as the count of industries in which the business group engages. As in the previous chapter, I use residuals after regressing count of industries on logged business group total assets to eliminate the size effect that may dominate the count of industries and minimize potential problems associated with multicollinearity.

The independent variable for Hypothesis 6a is a dummy variable that indicates whether the focal business group member firm operated in an industry related to the focal industry (yes =1). As in analyses presented in the previous chapter, I used the South Korean input-output table's 28 broader categorization of industries to determine

\footnotetext{
${ }^{18}$ I used total assets here because I use a variable (level of within group transaction) based on total sales and this variable may lead to a spurious regression result in combination with the total sales variable (Wiseman, 2009). I also tested using the logarithm of total sales to proxy business group size. As in the previous Chapter, the results were similar reflecting the close correlation of the two variables.
} 
the relatedness between industries. The independent variable for Hypothesis $6 \mathrm{~b}$ is a dummy variable that indicates whether another firm of the business group to which the focal firm belongs already operated in the focal industry. The presence of other business group member firms in the focal industry is measured as a dummy variable (presence $=$ $1)$.

For the test of Hypothesis 7, the level of within-group transactions is measured by the percentage of within-group sales in total business group sales. The within-group transaction data are from the KFTC's large scale business group database.

Control variables. Many control variables are included in the empirical tests. I add these variables to control firm effect, business group effect, industry effect, and year effect. Firm control variables include age, profitability (earnings before interest and tax), research and development (R\&D) intensity, and scope of business (count of the industries in which the firm is present). ${ }^{19}$

A firm's age is an important factor in its diversification pattern because firms go through different stages throughout their life span, which affects their rate of growth and the pattern of their strategies (Agarwal, Sarkar, \& Echambadi, 2002; Miller \& Friesen, 1984). Profitability may lead either to more diversification through the increase in slack resources (Chatterjee \& Wernerfelt, 1988) or to less diversification because it may indicate that the firm's potential in its current markets is positive (Hoskisson \& Hitt,

\footnotetext{
${ }^{19}$ A firm's level of cash holdings is also an important factor in its corporate diversification because the firm's cash may serve as the most fungible slack resource for the diversifying firm (Jensen, 1986; Chatterjee \& Wernerfelt, 1988). On the other hand, widely diversified firms may hold less cash because they can spread risk across different businesses (Duchin, 2010; Opler, Pinkowitz, Stulz, \& Williamson, 1999). However, the logged form of this variable showed an extreme level of correlation with total assets $(\mathrm{r}=0.81)$, so I did not include the control variable in the models.
} 
1990). R\&D intensity has been found to be significantly related to a firm's diversification patterns (Baysinger \& Hoskisson, 1989). Finally, the existing scope of the firm may indicate the tendency of the firm's attitude and approach to diversification, but the existing scope may also constrain the firm's capability to pursue further diversification. I transformed the variable into the logarithm form by taking natural log after making all the values positive.

As business group control variables, I include the number of member firms, business group age, and group-wide profit. Group-wide profit may affect the likelihood of firm diversification either positively through the provision of free cash flow through internal capital markets (Khanna \& Palepu, 2000b) or negatively because of strategic inertia. The group-wide profit data are from the KFTC's database of major large scale business groups. The number of member firms and group-wide profit were adjusted to be independent from business group size following the same method employed in the previous chapter. For group-wide profit, I used the logarithmic transformation to make the distribution closer to normal.

I also included industry controls: size, strategic impact, and growth rate. I expected the bigger the industry, the more likely it is for a firm to enter. Firms may also prefer strategically important industries that have many linkages with other industries than isolated industries. Additionally, I expected the growth rate of an industry to positively affect the likelihood of a firm's entry. The size and growth rate of an industry was measured based on the total production value of the industry, based on data available from the Bank of Korea. 
In addition, I control for the annual growth rate of South Korean GDP to account for yearly fluctuation in national economic activities. All of the independent variables and control variables are lagged one year. Table 6 lists the variables and presents their definition and basic descriptive statistics. Table 7 shows pairwise correlations among the variables.

\section{Statistical methods}

For all of the hypotheses, the probability that a particular firm enters a particular industry in which it did not previously operate in a particular year is estimated. Therefore, logistic regression models are used to estimate the probabilities in question. As in Chapter III, I use two alternative statistical models to deal with the uniqueness of the dataset: multilevel logistic regression to account for the nested structure of the data (industries nested in firms) and Perth logistic regression (Firth, 1993) to deal with the fact that a firm's entry to a new industry is a rare event (Heinze \& Schemper, 2002). In the sample, among 59,753 total observations, there were 73 cases of entry, which constitute approximately 0.12 percent of all the observations.

\section{Results}

Table 8 presents the results of hypothesis tests. Column (1) shows the logistic regression model with only the control variables. The coefficient for firm age is negative and statistically significant, showing that older firms are less active in terms of new industry entries. The coefficient for firm scope is positive and highly statistically significant. This may imply that firms have the tendency to keep diversifying once they start diversifying. These two control variables remain statistically significant across all 
the different models. On the other hand, strategic importance of an industry is positive and highly statistically significant in predicting the likelihood of firm entry to the industry in the control-only model, but it loses statistical significance once the variable indicating another business group member firm's presence in the industry is added to the model.

I examined the VIFs to check the potential multicollinarity issue using the ordinary least squares regression model equivalent to the model shown in column (6) (Hitt et al., 2006). Size of business group (measured by logged business group total assets) had the highest VIF (3.81) and the mean VIF was 1.74, which alleviate concerns of potential multicollinearity. Some of the pairwise correlation coefficients are high. The highest pairwise correlation is 0.59 between business group size and the level of within-group transaction. However, this figure is still well below the threshold suggested by Tabachnick and Fidell (2012).

I sequentially added each of the independent variables to see the stability of the overall model. Columns (2) to (6) show that the coefficients are largely stable throughout this process. ${ }^{20}$ Except for the model in Column (2), the fit of every model shows a statistically significant improvement based on Bayesian Information Criterion.

\footnotetext{
${ }^{20}$ The group size variable approaches statistical significant at $95 \%$ confidence level with a negative coefficient when the variable indicating the presence of a business group member firm in the given industry, but the group size variable loses any significance when the interdependence variable is added. This may be due to high correlations among these three variables. Given the high correlation between business group size and the interdependence variable, I also tested a model with the size-adjusted interdependence variable, using the same technique that I used in Chapter III. In this model, the coefficient of the group size variable was negative and significant at $90 \%$ confidence level. In any case, these results do not support Hypothesis 4a.
} 
Column (6) of Table 8 shows the result of the logistic regression analysis with all of the independent variables and control variables. Columns (7) and (8) show the results of the multilevel logistic regression and the Firth logistic regression, respectively. There are some differences, but all three analyses yielded largely comparable results. Therefore, I will simply refer to the result outlined in column (6) when I discuss the specific hypothesis testing results.

Hypothesis 4a predicted that a business group's size would be positive in the likelihood of its member firms' entry into a new industry. However, the coefficient for group size is negative and non-significant $(\mathrm{p}=0.57)$. Therefore, Hypothesis $4 \mathrm{a}$ is not supported. Because the main relationship does not hold, Hypothesis $4 \mathrm{~b}$ is also not supported.

Hypothesis 5 predicted that as the level of business group diversification goes up, the member firm's incentive to diversify will diminish. The coefficient for group diversity is negative and highly statistically significant $(\mathrm{p}<0.01)$, providing support for the hypothesis.

Hypothesis 6a predicted that business group member firms would tend to diversify into industries to which their existing business portfolio is related. The coefficient for the dummy variable indicating the firm's presence in related industries is positive and highly statistically significant $(\mathrm{p}<0.01)$, which supports the hypothesis. On the other hand, Hypothesis $6 \mathrm{~b}$ predicted that business group member firms would have the tendency to diversify into industries in which other firms within the group are already operate. The coefficient for the dummy variable indicating a business group 
sister firm's presence in the focal industry is positive and highly statistically significant ( $\mathrm{p}<0.01)$, lending support to the hypothesis.

Hypothesis 7 predicted that interdependence among business group member firms that is evidenced by the level of within-group transactions would lead to a lower likelihood of the member firm's entry to a new industry. The coefficient for interdependence is negative and statistically significant $(\mathrm{p}<0.05)$, supporting the hypothesis.

As Table 8 shows, Hypotheses 5 through 7 are supported in the alternative modeling approaches as well.

\section{Discussion}

In Chapter III, I argued that the purpose of business group diversification is different from that of firm diversification. I suggested that because a business group forms a special marketplace where its member firms can transact with one another with trust, the controlling shareholders of the business group would try to maximize the impact of the entry to an additional industry by targeting industries that have linkages with many other industries. Empirical tests of the idea clearly showed that major Korean business groups tend to make new entries to such strategically impactful industries. By entering those industries and operating in them, a business group can have the widest possible coverage of the entire national economy at a given level of diversification.

Based on the aforementioned idea, this chapter explored implications of the idea for business group member firms, which are at once legally independent entities and constituents of the special marketplace represented by the business group. As has been 
already noted, prior research has routinely used a membership to any business group to assess economic consequences of a business group by examining the performance difference between business group member firms and stand-alone firms (e.g., Khanna \& Palepu, 2000a, b; Khanna \& Rivkin, 2001). This approach takes account of the fact that a business group member firm is independent despite its membership to the business group, but do not consider anything about the characteristics of the special marketplace in which the firm operates. As the firm may draw various benefits from this marketplace, the firm will be certainly motivated to maximize the benefits arising from business group membership. Such motivation will affect a variety of strategic decisions of the firm. In this chapter, I specifically focused on business group member firms' diversification and argued that the characteristics of the business group to which a firm belongs affect its diversification pattern.

Hypothesis $4 \mathrm{a}$ and Hypothesis $4 \mathrm{~b}$, which focused on the effect of business group size on member firm diversification likelihood, did not get any empirical support. The results may show that simply having a bigger marketplace in the form of a larger business group may not have an effect (positive or negative) on a member firm's diversification pattern even though business group size may provide member firms with various advantages (Carney, 2004; Guillén, 2000; Khanna \& Yafeh, 2007).

The strong empirical support for Hypothesis 5 and Hypothesis 7, which focus on the degree of diversification and the level of intragroup transaction respectively, further undergirds this conclusion. The empirical support of Hypothesis 5 suggests that the controlling shareholders of a business group can induce its member firms to focus on 
their core activities by expanding the industry coverage of the business group as a whole. The empirical support of Hypothesis 7 suggests that by designing the overall structure of a business group so that more transactions may occur within the boundary of the business group, the controlling shareholders will be able to encourage the member firms to focus. In other words, the empirical supports for these two hypotheses suggest that no matter how large a business group may be, if it is not designed and managed optimally, it may not constrain its member firms' diversification. On the flip side, the results insinuate that the controlling shareholders may not need to try to manage member firms directly or force them to pursue the collective interest of the business group because the controlling shareholders may be able to affect the firms' strategic patterns simply by defining specific characteristics of the overall business group.

Hypothesis $6 \mathrm{a}$ and Hypothesis $6 \mathrm{~b}$ are not directly about the effect of business group characteristics, but they provide some of the reasons that we should not approach business group diversification only at either the member firm level or the business group level.

The empirical support for Hypothesis 6a shows that at least at the firm level, the argument that business groups tend to diversify excessively into unrelated industries is misplaced. As legally independent entities, business group firms are likely to enter an industry that is related to their existing industry portfolio, following the relatedness criterion (Rumelt, 1974). Even though I only used business group member firms for empirical tests, the theory laid out in this dissertation suggests that business group member firms may have less need for diversifying widely than stand-alone firms 
because group member firms may access various resources embedded not just within their boundaries but also within the overall business group boundary to which they belong (Lamin, 2013; Manikandan \& Ramachandran, 2014).

In particular, the empirical support for Hypothesis $6 \mathrm{~b}$ leads to a highly interesting implication. The hypothesis deals with the fact that multiple business group members often participate in the same industry complementing one another's business and cooperating with one another (Choi \& Cowing, 2002; Lee \& He, 2009). Even though this phenomenon is pretty common in major business groups, previous research that either focuses on the firm level or the business group level could not deal with the possibility of industry domain overlap. In firm-level studies, what other member firms do within the boundary of the same business groups is mostly ignored. Even when specific business groups to which the firms belong are considered, business group variables are typically aggregated (e.g., Chang \& Hong, 2000), which hinders the examination of the activities of specific firms within a business group. In business group-level studies, diversification has been commonly examined only on the dimension of breadth of industry portfolio simulating firm-level diversification studies, so any overlap has been ignored.

Industry overlaps among business group member firms may lead to close collaborations and intensive knowledge sharing rather than intense competition with one another. Given that one of the most important characteristics of the business group form is trust arising from informal ties, which are often family-based, the role of the business 
group form in facilitating complex multilateral alliances among member firms without elaborate governance mechanisms may need to be highlighted (Li et al., 2012). 


\section{CHAPTER V}

\section{CONCLUSIONS}

In this dissertation, I put forth the idea that business groups diversify for reasons that are different from those of firms. I emphasized business groups' market-like nature and argued that the controlling shareholders of a business group would want the maximum coverage of the entire economy at a given level of diversification by entering strategic industries that have linkages to many other industries. In turn, business group member firms, as legally independent entities, will base their diversification decisions on the characteristics of the business group to which they belong, so that they may reap the maximum benefit of membership. I argued that as a business group becomes more diversified and its level of intragroup transactions goes up, its member firms will be less likely to pursue wide diversification of their own. Additionally, I proposed that business group member firms will follow the relatedness criterion but they will also use the criterion not just in connection to their own industry portfolio, but also in relation to the portfolios of other member firms within the same business group. I found empirical support for a majority of my hypotheses using the data of 30 major Korean business groups and their 108 member firms. Table 9 summarizes the results of the empirical testing in this dissertation.

\section{Implications}

My findings clearly indicate the need to examine the business group in a way that takes account of both of its double boundaries (Granovetter, 1995). 
Most previous studies of business groups tend to focus on their member firms as units of analysis because business groups have been regarded as anomalies that cannot be explained neatly based on existing firm-based theories (Heugens \& Zyglidopoulos, 2008). Therefore, business group membership has often been reduced to a firm-level dummy variable that simply captures whether the firm is a business group member firm or not.

The business group homogeneity assumption that underlies this approach is much like the firm homogeneity assumption that the field of strategic management has helped to overcome with the resource-based view (Wernerfelt, 1984; Barney, 1991). Given the complexity of the business group structure and the increasing importance of the business group form in the world economy, it is important to overcome this unrealistic and constraining assumption and explore this organizational form in a way that considers its unique purposes.

By showing that business groups follow a diversification criterion that is different from that of firms, this dissertation sheds light on one such unique purpose: expanding its provision of strategic resources to member firms. As a multi-firm organization, the business group is uniquely suited to take advantage of the inherent linkages among diverse industries. As technological innovation leads to an increasing level of industry convergence (Benner \& Tripsas, 2012), the incompleteness of strategic factor markets (Denrell et al., 2003) may increasingly reward the business group's capability to provide its member firms with potential growth opportunities through combining their own resources with resources available through fellow member firms 
(Manikandan \& Ramachandran, 2014; Lamin, 2013). When we consider market imperfection in general rather than market imperfection that is specific to a certain institutional environment, we realize that the business group form may actually be highly relevant to today's changing economic landscape characterized by technological innovations and industry convergences.

Taking account of the market-like nature of the business group also lead to the realization that for the member firms of the business group, it is a special environment to which they need to adjust. This environment may be considered as a type of institution and institutional theory suggests that the member firms will form their strategic directions in consideration of this institution. If diversification behavior is different across countries because of different national institutions as suggested by Kogut, Walker, and Anand (2002), it is reasonable to expect that member firms to different business groups would display different diversification behaviors. The findings in this dissertation clearly show that the structure of the business group affects its member firms' choices in diversification.

Viewing the business group not just as a resource provider but also as an environment that may define its member firms' strategic directions has an implication for both the controlling shareholders and minority shareholders. For the controlling shareholders, it means they can encourage individual member firms to focus on and improve their core activities by providing the widest coverage of the entire economy at a given diversification level of the business group. By showing that business groups target industries with multiple linkages for diversification, this dissertation supports the idea 
that the wide diversification of the business group may be purposeful and strategic rather than haphazard and opportunistic.

For minority shareholders, the tendency of business group member firms to focus on their core activities rather than diversify widely into unrelated industries is welcome because minority shareholders can easily diversify their investment portfolio. Along with the potential growth opportunities arising from the diverse strategic resources available within the business group boundary (Manikandan \& Ramachandran, 2014), this tendency may be an important factor that draws minority shareholders to invest in business group member firms rather than shun away from them worrying about potential opportunistic behaviors of the controlling shareholders.

Overall, this dissertation shows the positive potential of the business group. I suspect business groups are going to further grow and prosper rather than wither away. In light of the potential, I believe we need to worry more about how to level the playing field for stand-alone firms rather than about how antiquated and dysfunctional business groups are. Business groups are already dominating many national economies across the world. Some of them are already global players and have the potential to exert increasing influence on the world economy as a whole.

\section{Limitations and Future Studies}

This dissertation only touches a tiny piece of the potential effects of the business group, but still suffers from some limitations.

First, in this dissertation, a business group's diversification through the creation or addition of a new firm is considered simply as changes to the business group's 
structural characteristics through which group member firms may potentially be affected. In reality, this form of diversification may directly affect certain member firms because in some cases, new firms are created through reorganizations of other member firms within the group.

Second, if data are available, intragroup transactional relationships may be analyzed based on specific transactions among member firms rather than on the aggregated sale and purchase amounts across all the member firms. Examining specific transactional relationships will help identify different types of relationships possible among member firms within the business group by detecting the direction of transactions and the number of intragroup transaction partners.

Third, the empirical tests of the ideas in this dissertation are based only on a limited number of major business groups and their member firms in just one country. Business groups are very diverse across countries, so the generalizability of the empirical results may be at issue. Even though several recent studies of Indian business groups (Manikandan \& Ramachandran, 2014; Lamin, 2013; Siegel \& Choudhury, 2012) provide some indirect indication that the logic that this dissertation proposes can be applied to business groups in other countries, studies of business groups from more countries will obviously help strengthen the empirical support of the ideas.

The business group effect, which has been commonly reduced to a single dummy variable in prior empirical studies, may be much more substantial and varied than what has been presented in this dissertation, which has focused only on the product diversification pattern of a business group and how it may affect firm-level product 
diversification decisions. Therefore, future studies may explore the business group effect in many other settings.

An obvious opportunity to extend the logic I propose in this dissertation lies in the topic of international diversification, which the dissertation does not cover. The international diversification of a business group may be approached in a manner that is similar to that of this dissertation. Specifically, we can examine the overall business group level international diversification as well as each business group's international diversification pattern, which is likely to be influenced by the group level international diversification through potential factors such as resource endowments, exchanges of information and knowledge, and opportunities for cooperation and alliance with other member firms within the business group. This inquiry will also provide research insights for emerging market multinational enterprises, most of which are member firms of business groups (Hoskisson, Kim, White, \& Tihanyi, 2004).

One other issue that should be considered in future studies is a divergence in performance at two different levels (group-level and firm-level) and its impact on member firms' diversification choices. Scholars note that poor performance may lead to a firm's diversification (Hoskisson \& Hitt, 1990). In the business group setting, a member firm may be affected not only by its own performance but also by the collective performance of the group. Moreover, each member of the group may display a different sensitivity to group-wide performance in forming its own strategy based on the firm's unique position and characteristics within the business group. 
Also important to consider in future work on business groups are group-level competitive dynamics. It is noted that competition occurs not only among firms, but also among groups of firms (Gomes-Casseres, 2003; Heugens \& Zyglidopoulos, 2008). It would be interesting to ask whether the rivalry among two business groups would affect firm-level strategic decisions and firm-level competitive dynamics.

Finally, the fact that most business groups are family-controlled compels us to ask fundamental questions about the underpinning of the business group form. Most large firms in many national economies belong to business groups controlled by families (La Porta et al., 1999). Most families run a portfolio of firms rather than just a single firm (Zellweger, Nason, Nordqvist, \& Brush, 2011). What factors drive the decision to form a business group? What makes family so advantageous in forming a business group? Why do families tend to diversify by forming a business group rather than by adding divisions within a firm? These are largely unanswered research questions that need to be explored.

Scholars that emphasize the notion of socioemotional wealth have argued that family firms diversify less than non-family firms (Gomez-Mejia, Cruz, Berrone, \& De Castro, 2011; Gomez-Mejia, Makri, \& Kintana, 2010; Anderson \& Reeb, 2003). The scholars argue that families do not want to lose their socioemotional wealth by getting too far away from their core business domain. However, if the business group is a typical way for a family to diversify into many different industries, can we still say that family businesses tend not to diversify widely? The empirical studies of family firm diversification have largely ignored the presence of business groups. We may need to 
reexamine the validity of this line of research by taking account of family businesses diversifying through the business group formation.

\section{Concluding Remarks}

This dissertation suggests a new perspective on business group diversification by examining it at two different levels: the business group level and the member firm level. For the business group level, I proposed that the purpose of group-level diversification should be different from that of firm-level diversification given the business group's market-like nature. For the member firm level, I emphasized the fact that business group member firms are both supported and constrained in making their diversification decisions by the characteristics of the business group to which they belong.

My perspective reveals an important weakness in prior research, which simply considers business group membership as the only difference between business group member firms and non-member firms. Whether business group member firms are efficient cannot be determined simply by making comparisons with non-member firms because business group member firms' strategic decisions are affected by the opportunities and constraints that arise from their business group membership, which cannot be reduced to a single dummy variable.

The wide diversification of a business group, unlike that of a firm, may not be so negative after all. It may act as a kind of governance device for its member firms by making them focus on their core activities and developing them further rather than diversify widely on their own. The structure of a business group may determine how 
much autonomy its member firms have, how cooperative they are, and how economically productive the overall group becomes. 


\section{REFERENCES}

Acemoglu, D., Johnson, S., \& Mitton, T. 2009. Determinants of vertical integration: Financial development and contracting costs. Journal of Finance, 64(3): 12511290.

Adler, P. 2001. Market, hierarchy, and trust: The knowledge economy and the future of capitalism. Organization Science, 12(2): 215-234.

Agarwal, R., Sarkar, M. B., \& Echambadi, R. 2002. The conditioning effect of time on firm survival: An industry life cycle approach. Academy of Management Journal, 45(5): 971-994.

Aghion, P., \& Tirole, J. 1995. Some implications of growth for organizational form and ownership structure. European Economic Review, 39: 440-455.

Ahuja, G., Polidoro, F., \& Mitchell, W. 2009. Structural homophily or social asymmetry? The formation of alliances by poorly embedded firms. Strategic Management Journal, 30: 941-958.

Alesina, A., Spolaore, E., \& Wacziarg, R. 2005. Trade, growth and the size of countries. In P. Aghion, \& S. N. Durlauf (Eds.), Handbook of economic growth, Vol. 1B: 1499-1542. Burlington, MA: Elsevier.

Altomonte, C., \& Rungi, A. 2012. Business groups as hierarchies of firms: Determinants of vertical integration and performance. Working paper no. 2013-135, Paolo Baffi Centre, Bocconi University, Milan, Italy. 
Amihud, Y., \& Lev, B. 1981. Risk reduction as a managerial motive for conglomerate mergers. Bell Journal of Economics, 12(2): 605-617.

Amihud, Y., \& Lev, B. 1999. Does corporate ownership structure affect its strategy towards diversification? Strategic Management Journal, 20: 1063-1069.

Amit, R., \& Wernerfelt, B. 1990. Why do firms reduce business risk? Academy of Management Journal, 33(3): 520-533.

Amsden, A. H., \& Hikino, T. 1994. Project execution capability, organizational knowhow and conglomerate corporate growth in late industrialization. Industrial and Corporate Change, 3: 111-147.

Anderson, R. C., \& Reeb, D. M. 2003. Founding-family ownership, corporate diversification, and firm leverage. Journal of Law and Economics, 46(2): 653684.

Ansoff, H. I. 1987. The emerging paradigm of strategic behavior. Strategic Management Journal, 8(6): 501-515.

Argyres, N. S. 1996. Evidence on the role of firm capabilities in vertical integration decisions. Strategic Management Journal, 17: 129-150.

Argyres, N. S. 2011. Using organizational economics to study organizational capability development and strategy. Organization Science, 22(5): 1138-1143.

Bae, K.-H., \& Jeong, S. W. 2007. The value-relevance of earnings and book value, ownership structure, and business group affiliation: Evidence from Korean business groups. Journal of Business Finance \& Accounting, 34(5-6): 740-766. 
Bae, K.-H., Kang, J.-K., \& Kim, J. M. 2002. Tunneling or value added? Evidence from mergers by Korean business groups. Journal of Finance, 57(6): 2695-2740.

Barney, J. B. 1986. Strategic factor markets: Expectations, luck, and business strategy. Management Science, 32(10): 1231-1241.

Barney, J. B. 1991. Firm resources and sustained competitive advantage. Journal of Management, 17(1): 99-120.

Baysinger, B., \& Hoskisson, R. E. 1989. Diversification strategy and R\&D intensity in multiproduct firms. Academy of Management Journal, 32(2): 310-332.

Belenzon, S., \& Berkovitz, T. 2010. Innovation in business groups. Management Science, 56(3): 519-535.

Belenzon, S., Patacconi, A., \& Zelner, B. A. 2012a. Identifying archetypes: an empirical study of business group structure in 16 developed economies. Working paper. Available at: https://faculty.fuqua.duke.edu/ sb135/bio/BPZ\%2013-01-26.pdf

Belenzon, S., Patacconi, A., \& Zelner, B. A. 2012b. Organizing the group: Agency, knowledge, and trust. Working paper. Available at: http://citeseerx.ist.psu.edu/viewdoc/download?doi=10.1.1.385.6960\&rep=rep1\&t ype $=$ pdf

Benner, M.J., \& Tripsas, M. 2012. The influence of prior industry affiliation on framing in nascent industries: The evolution of digital cameras. Strategic Management Journal, 33: 277-302. 
Berger, P. G., \& Ofek, E. 1995. Diversification's effect on firm value. Journal of Financial Economics, 37(1): 39-65.

Berle, A. A., \& Means, G. C. 1932. The modern corporation and private property. New York, NY: MacMillan.

Bertrand, M., Mehta, P., \& Mullainathan, S. 2002. Ferreting out tunneling: An application to Indian business groups. Quarterly Journal of Economics, 117(1): $121-148$.

Burt, R. S., Guilarte, M., Raider, H. J., \& Yasuda, Y. 2002. Competition, contingency, and the external structure of markets. In P. Ingram, \& B. S. Silverman (Eds.), The new institutionalism in strategic management, vol. 19: 167-217. Oxford, UK: Elsevier Science.

Cainelli, G., \& Iacobucci, D. 2011. Business groups and the boundaries of the firm. Management Decision, 49(9): 1549-1573.

Campbell, T. L., \& Keys, P. Y. 2002. Corporate governance in South Korea: The chaebol experience. Journal of Corporate Finance, 8: 373-391.

Carney, M. 2004. The institutions of industrial restructuring in Southeast Asia. Asia Pacific Journal of Management, 21: 171-188.

Carney, M. 2005. Corporate governance and competitive advantage in family-controlled firms. Entrepreneurship Theory and Practice, 29(3): 249-265.

Carney, M., Gedajlovic, E., Heugens, P., Van Essen, M., \& van Oosterhout, J. 2011. Business group affiliation, performance, context, and strategy: A meta-analysis. Academy of Management Journal, 54(3): 437-460. 
Caves, R. E., Porter, M. E., \& Spence, A. M. 1980. Competition in the open economy. Cambridge, MA: Harvard University Press.

Chakrabarti, A., Singh, K., \& Mahmood, I. P. 2007. Diversification and performance: Evidence from East Asian firms. Strategic Management Journal, 28: 101-120.

Chang, D. 1999. Privately owned social structures: Institutionalization-network contingency in the Korean chaebol. Unpublished doctoral dissertation, University of Chicago, Chicago, IL.

Chang, S.-J. 2003. Ownership structure, expropriation, and performance of groupaffiliated companies in Korea. Academy of Management Journal, 46(2): 238253.

Chang, S.-J. 2006. Business groups in East Asia: Post-crisis restructuring and new growth. Asia Pacific Journal of Management, 23(4): 407-417.

Chang, S.-J., \& Choi, U. 1988. Strategy, structure and performance of Korean business groups: A transactions cost approach. Journal of Industrial Economics, 37(2): $141-158$.

Chang, S.-J., \& Hong, J. 2000. Economic performance of group-affiliated companies in Korea: Intragroup resource sharing and internal business transactions. Academy of Management Journal, 43(3): 429-448.

Chang, S.-J., \& Hong, J. 2002. How much does the business group matter in Korea? Strategic Management Journal, 23(3): 265-274.

Chang, S.-J., \& Singh, H. 2000. Corporate and industry effects on business unit competitive position. Strategic Management Journal, 21(7): 739-752. 
Chatterjee, S. 1986. Types of synergy and economic value: The impact of acquisitions on merging and rival firms. Strategic Management Journal, 7(2): 119-139.

Chatterjee, S., \& Wernerfelt, B. 1988. Related or unrelated diversification: A resource based approach. Academy of Management Best Papers Proceedings, 8(1): 7-11.

Chatterjee, S., \& Wernerfelt, B. 1991. The link between resources and type of diversification: Theory and evidence. Strategic Management Journal, 12(1): 3348.

Chenery, H. B., \& Watanabe, T. 1958. International comparisons of the structure of production. Econometrica, 26(4): 487-521.

Child, J., \& McGrath, R. G. 2001. Organizations unfettered: Organizational form in an information-intensive economy. Academy of Management Journal, 44(6): 11351148.

Choi, J.-P., \& Cowing, T. G. 2002. Diversification, concentration and economic performance: Korean business groups. Review of Industrial Organization, 21: 271-282.

Chung, C.-N., \& Luo, X. R. 2008. Human agents, contexts, and institutional change: The decline of family in the leadership of business groups. Organization Science, 19(1): 124-142.

Claessens, S., Djankov, S., Fan, J. P., \& Lang, L. H. 2002. Disentangling the incentive and entrenchment effects of large shareholdings. Journal of Finance, 57(6): 2741-2771. 
Claessens, S., Djankov, S., \& Lang, L. H. 2000. The separation of ownership and control in East Asian corporations. Journal of Financial Economics, 58: 81-112.

Claessens, S., Fan, J., \& Lang, L. H. 2006. The benefits and costs of group affiliation: Evidence from East Asia. Emerging Markets Review, 7: 1-26.

Coase, R. 1937. The nature of the firm. Economica, 4(16): 386-405.

Coff, R. 1999. When competitive advantage doesn't lead to performance: The resourcebased view and stakeholder bargaining power. Organization Science, 10(2): 119133.

Cohen, W. M., \& Levinthal, D. A. 1990. Absorptive capacity: A new perspective on learning and innovation. Administrative Science Quarterly, 35(1): 128-152.

Colpan, A. M., \& Hikino, T. 2010. Foundations of business groups: Towards an integrated framework. In A. M. Colpan, T. Hikino, \& J. R. Lincoln (Eds.), The Oxford handbook of business groups: 15-66. New York, NY: Oxford University Press.

Coveney, J. 2008. Firthlogit: Stata module to calculate bias reduction in logistic regression, Available at: http://EconPapers.repec.org/RePEc:boc:bocode:s456948.

D'Aveni, R., Dagnino, G., \& Smith, K. G. 2010. The age of temporary advantage. Strategic Management Journal, 31: 1371-1385.

Das, T., \& Teng, B.-S. 1998. Between trust and control: Developing confidence in partner cooperation in alliances. Academy of Management Review, 23(3): 491512. 
Denrell, J., Fang, C., \& Winter, S. G. 2003. The economics of strategic opportunity. Strategic Management Journal, 24: 977-990.

Dewaelheyns, N., \& Van Hulle, C. 2006. Corporate failure prediction modeling: Distorted by business groups' internal capital markets? Journal of Business Finance \& Accounting, 33(5-6): 909-931.

Dharwadkar, B., George, G., \& Brandes, P. 2000. Privatization in emerging economies: An agency theory perspective. Academy of Management Review, 25(3): 650669.

Duchin, R. 2010. Cash holdings and corporate diversification. Journal of Finance, 65(3): 955-992.

Dyer, J., \& Chu, W. 2010. The determinants of trust in supplier-automaker relations in the US, Japan, and Korea: A retrospective. Journal of International Business Studies, 42(1): 28-34.

Echambadi, R., Campbell, B., \& Agarwal, R. 2006. Encouraging best practice in quantitative management research: An incomplete list of opportunities. Journal of Management Studies, 43(8): 1801-1820.

Edwards, J. R. 2009. Seven deadly myths of testing moderation in organizational research. In C. Lance, \& R. Vandenberg (Eds.): Statistical and methodological myths and urban legends: Doctrine, verity and fable in the organizational and social sciences, 143-164. New York, NY: Routledge. 
Ferris, S. P., Kim, K. A., \& Kitsabunnarat, P. 2002. The costs (and benefits?) of diversified business groups: The case of Korean chaebols. Journal of Banking \& Finance, 27(2): 251-273.

Fiegenbaum, A., \& Thomas, H. 1988. Attitudes toward risk and the risk-return paradox: Prospect theory explanations. Academy of Management Journal, 31(1): 85-106.

Firth, D. 1993. Bias reduction of maximum likelihood estimates. Biometrika, 80(1): 2738.

Fong, E. A., Misangyi, V. F., \& Tosi, H. L. 2009. The effect of CEO pay deviations on CEO withdrawal, firm size, and firm profits. Strategic Management Journal, 31: 629-651.

Friedman, E., Johnson, S., \& Mitton, T. 2003. Propping and tunneling. Journal of Comparative Economics, 31(4): 732-750.

Ghemawat, P., \& Khanna, T. 1998. The nature of diversified business groups: A research design and two case studies. Journal of Industrial Economics, 46(1): $35-61$.

Gomes-Casseres, B. 2003. Competitive advantage in alliance constellations. CrossCultural Research, 1(3): 327-335.

Gomes, A. 2000. Going public without governance: Managerial reputation effects. Journal of Finance, 55(2): 615-646.

Gomez-Mejia, L. R., Cruz, C., Berrone, P., \& De Castro, J. 2011. The bind that ties: Socioemotional wealth preservation in family firms. Academy of Management Annals, 5(1): 653-707. 
Gomez-Mejia, L. R., Makri, M., \& Kintana, M. L. Diversification decisions in familycontrolled firms. Journal of Management Studies, 47(2): 223-252.

Granovetter, M. 1995. Coase revisited: Business groups in the modern economy. Industrial and Corporate Change, 4(1): 93-130.

Grant, R. M., Jammine, A. P., \& Thomas, H. 1988. Diversity, diversification, and profitability among British manufacturing companies, 1972-84. Academy of Management Journal, 31(4): 771-801.

Guillén, M. F. 2000. Business groups in emerging economies: A resource-based view. Academy of Management Journal, 43(3): 362-380.

Guillén, M. F. 2010. Capability building in business groups. In A. M. Colpan, T. Hikino, \& J. R. Lincoln (Eds.), The Oxford handbook of business groups: 743-762. New York, NY: Oxford University Press.

Gupta, A. K., Smith, K. G., \& Shalley, C. 2006. The interplay between exploration and exploitation. Academy of Management Journal, 49(4): 693-706.

Hannan, M., \& Freeman, J. 1977. The population ecology of organizations. American Journal of Sociology, 82(5): 929-964.

Hayek, F. 1945. The use of knowledge in society. American Economic Review, 35(4): 519-530.

Heinze, G., \& Schemper, M. 2002. A solution to the problem of separation in logistic regression. Statistics in Medicine, 21: 2409-2419. 
Heugens, P. P. M. A. R., \& Zyglidopoulos, S. C. 2008. From social ties to embedded competencies: The case of business groups. Journal of Management \& Governance, 12(4): 325-341.

Hirschman, A. O. 1958. The strategy of economic development. New Haven, CT: Yale University Press.

Hitt, M. A., Bierman, L., Uhlenbruck, K., \& Shimizu, K. 2006. The importance of resources in the internationalization of professional service firms: The good, the bad, and the ugly. Academy of Management Journal, 49(6): 1137-1157.

Hitt, M. A., Hoskisson, R. E., \& Ireland, R. D. 1994. A mid-range theory of the interactive effects of international and product diversification on innovation and performance. Journal of Management, 20(2): 297-326.

Hoskisson, R. E., \& Hitt, M. A. 1988. Strategic control systems and relative R\&D investment in large multiproduct firms. Strategic Management Journal, 9(6): 605-621.

Hoskisson, R. E., \& Hitt, M. A. 1990. Antecedents and performance outcomes of diversification: A review and critique of theoretical perspectives. Journal of Management, 16(2): 461-509.

Hoskisson, R. E., Hitt, M. A., Johnson, R. A., \& Moesel, D. D. 1993. Construct validity of an objective (entropy) categorical measure of diversification strategy. Strategic Management Journal, 14(3): 215-235.

Hoskisson, R. E., Kim, H., White, R. E., \& Tihanyi, L. 2004. A framework for understanding international diversification by business groups from emerging 
markets. In M. A. Hitt, \& J. L. C. Cheng (Eds.), Advances in international management: vol. 16: 137-163. New York, NY: Elsevier.

Hoskisson, R. E., Johnson, R. A., Tihanyi, L., \& White, R. 2005. Diversified business groups and corporate refocusing in emerging economies. Journal of Management, 31(6): 941-965.

Huber, P. J. 1967. The behavior of maximum likelihood estimates under nonstandard conditions, Proceedings of the fifth Berkeley symposium on mathemetical statistics and probability, Vol. 1: Statistics, 221-233. Berkeley, CA: University of California Press.

Ito, K., \& Pucik, V. 1993. R\&D spending, domestic competition, and export performance of Japanese manufacturing firms. Strategic Management Journal, 14(1): 61-75.

Jacobides, M. G. 2008. How capability differences, transaction costs, and learning curves interact to shape vertical scope. Organization Science, 19(2): 306.

Jacobides, M. G., \& Winter, S. G. 2005. The co-evolution of capabilities and transaction costs: Explaining the institutional structure of production. Strategic Management Journal, 26(5): 395-413.

Jawahar, I. M., \& McLaughlin, G. L. 2001. Toward a descriptive stakeholder theory: An organizational life cycle approach. Academy of Management Review, 26(3): $397-414$.

Jensen, M. C. 1986. Agency costs of free cash flow, corporate finance, and takeovers. American Economic Review, 76(2): 323-329. 
Jensen, M. C., \& Meckling, W. 1976. Theory of the firm: Managerial behavior, agency costs and ownership structure. Journal of Financial Economics, 3(4): 305-360.

Jia, N., Shi, J., \& Wang, Y. 2013. Coinsurance within business groups: Evidence from related party transactions in an emerging market. Management Science, 59(10): 2295-2313.

Johnson, S., La Porta, R., Lopez-de-Silanes, F., \& Shleifer, A. 2000. Tunneling. American Economic Review, 90(2): 22-27.

Jones, C., Hesterly, W., \& Borgatti, S. P. 1997. A General theory of network governance: Exchange conditions and social mechanisms. Academy of Management Review, 22(4): 911-945.

Jones, G., \& Hill, C. W. 1988. Transaction cost analysis of strategy-structure choice. Strategic Management Journal, 9: 159-172.

Jonsson, S., \& Regnér, P. 2009. Normative barriers to imitation: Social complexity of core competences in a mutual fund industry. Strategic Management Journal, 30(5): 517-536.

Kale, P., \& Singh, H. 2009. Managing strategic alliances: What do we know now, and where do we go from here? Academy of Management Perspectives, 23(3): 4562.

Kandel, E., Kosenko, K., Morck, R., \& Yafeh, Y. 2013. Business groups in the United States: A revised history of corporate ownership, pyramids and regulation, 1930-1950. Working paper no. 19691, National Bureau of Economic Research, Cambridge, MA. 
Kato, T., Kim, W., \& Lee, J. H. 2007. Executive compensation, firm performance, and chaebols in Korea: Evidence from new panel data. Pacific-Basin Finance Journal, 15(1): 36-55.

Keister, L. A. 1998. Engineering growth: Business group structure and firm performance in China's transition economy. American Journal of Sociology, 104(2): 404440.

Khanna, T. 2000. Business groups and social welfare in emerging markets: Existing evidence and unanswered questions. European Economic Review, 44(4): 748761.

Khanna, T., \& Palepu, K. G. 1997. Why focused strategies may be wrong for emerging markets. Harvard Business Review, 75(4): 41-51.

Khanna, T., \& Palepu, K. G. 2000a. The future of business groups in emerging markets: Long-run evidence from Chile. Academy of Management Journal, 43(3): 268285.

Khanna, T., \& Palepu, K. G. 2000b. Is group affiliation profitable in emerging markets? An analysis of diversified Indian business groups. Journal of Finance, 55(2): 867-891.

Khanna, T., \& Rivkin, J. W. 2001. Estimating the performance effects of business groups in emerging markets. Strategic Management Journal, 22(1): 45-74.

Khanna, T., \& Yafeh, Y. 2005. Business groups and risk sharing around the world. Journal of Business, 78(1): 301-340. 
Khanna, T., \& Yafeh, Y. 2007. Business groups in emerging markets: Paragons or parasites? Journal of Economic Literature, 45(2): 331-372.

Kim, H., \& Hoskisson, R. E. 1996. Japanese governance system: A critical review. In S. B. Prasad (Ed.), Advances in International Comparative Management, Vol. 11: 165-190. Greenwich, CT: JAI Press

Kim, H., Hoskisson, R. E., Tihanyi, L., \& Hong, J. 2004. The evolution and restructuring of diversified business groups in emerging markets: The lessons from chaebols in Korea. Asia Pacific Journal of Management, 21(1): 25-48.

Kim, W. C., Hwang, P., \& Burgers, W. P. 1989. Global diversification strategy and corporate profit performance. Strategic Management Journal, 10: 45-57.

Klein, P. G., \& Lien, L. B. 2009. Diversification, industry structure, and firm strategy: An organizational economics perspective. In B. S. Silverman (Ed.), Advances in strategic management, Vol. 26: 289-312. Bingley, UK: Emerald Group Publishing.

Kock, C. J., \& Guillén, M. F. 2001. Strategy and structure in developing countries: Business groups as an evolutionary response to opportunities for unrelated diversification. Industrial and Corporate Change, 10(1): 77-113.

Kogut, B., \& Zander, U. 1996. What firms do? Coordination, identity, and learning. Organization Science, 7(5): 502-518.

Kogut, B., Walker, G., \& Anand, J. 2002. Agency and institutions: National divergences in diversification behavior. Organization Science, 13(2): 162-178. 
La Porta, R., Lopez-de-Silanes, F., \& Shleifer, A. 1999. Corporate ownership around the world. Journal of Finance, 54(2): 471-517.

Lamin, A. 2013. Business groups as information resource: An investigation of business group affiliation in the Indian software services industry. Academy of Management Journal, 56(5): 1487-1509.

Langlois, R. 2010. Economic institutions and the boundaries of business groups. In A. M. Colpan, T. Hikino, \& J. R. Lincoln (Eds.), The Oxford handbook of business groups: 629-649. New York, NY: Oxford University Press.

Lee, K., \& He, X. 2009. The capability of the Samsung group in project execution and vertical integration: Created in Korea, replicated in China. Asian Business \& Management, 8(3): 277-299.

Lee, K., Peng, M. W., \& Lee, K. 2008. From diversification premium to diversification discount during institutional transitions. Journal of World Business, 43: 47-65.

Leff, N. H. 1978. Industrial organization and entrepreneurship in the developing countries: The economic groups. Economic Development and Cultural Change, 26(4): 661-675.

Leiblein, M. J., \& Madsen, T. 2009. Unbundling competitive heterogeneity: Incentive structures and capability influences on technological innovation. Strategic Management Journal, 30: 711-735.

Lemelin, A. 1982. Relatedness in the patterns of interindustry diversification. Review of Economics and Statistics, 64(4): 646-657. 
Leontief, W. W. 1986. Input-output economics (2nd ed.). New York, NY: Oxford University Press.

Li, D., Eden, L., Hitt, M. A., \& Ireland, R. D. 2008. Friends, acquaintances, or strangers? Partner selection in R\&D alliances. Academy of Management Journal, 51(2): 315-334.

Li, D., Eden, L., Hitt, M. A., Ireland, R. D., \& Garrett, R. P. 2012. Governance in multilateral R\&D alliances. Organization Science, 23(4): 1191-1210.

Luo, X. R., \& Chung, C.-N. 2005. Keeping it all in the family: The role of particularistic relationships in business group performance during institutional transition. Administrative Science Quarterly, 50(3): 404-439.

Mahmood, I. P., Chung, C.-N., \& Mitchell, W. 2013. The evolving impact of combinatorial opportunities and exhaustion on innovation by business groups as market development increases: The case of Taiwan. Management Science, 59(5): 1142-1161.

Mahmood, I. P., \& Lee, C. Y. 2004. Business groups: Entry barrier-innovation debate revisited. Journal of Economic Behavior and Organization, 54: 513-531.

Mahmood, I. P., \& Mitchell, W. 2004. Two faces: Effects of business groups on innovation in emerging economies. Management Science, 50(10): 1348-1365.

Mahmood, I. P., Zhu, H., \& Zajac, E. J. 2011. Where can capabilities come from? Network ties and capability acquisition in business groups. Strategic Management Journal, 32: 820-848. 
Mahnke, V., Venzin, M., \& Zahra, S. A. 2007. Governing entrepreneurial opportunity recognition in MNEs: Aligning interests and cognition under uncertainty. Journal of Management Studies, 44(7): 1278-1298.

Mahoney, J. T., \& Pandian, J. 1992. The resource-based view within the conversation of strategic management. Strategic Management Journal, 13: 363-380.

Manikandan, K. S., \& Ramachandran, J. 2014. Beyond institutional voids: Business groups, incomplete markets, and organizational form. Strategic Management Journal. doi: 10.1002/smj.2226

Markides, C. C. 1992. Consequences of corporate refocusing: Ex ante evidence. Academy of Management Journal, 35(2): 398-412.

Markides, C. C., \& Williamson, P. 1996. Corporate diversification and organizational structure: A resource-based view. Academy of Management Journal, 39(2): 340-367.

Markides, C. C., \& Williamson, P. J. 1994. Related diversification, core competences and corporate performance. Strategic Management Journal, 15: 149-165.

Martin, J. D., \& Sayrak, A. 2003. Corporate diversification and shareholder value: A survey of recent literature. Journal of Corporate Finance, 9: 37-57.

Masulis, R. W., Pham, P. K., \& Zein, J. 2011. Family business groups around the world: Financing advantages, control motivations, and organizational choices. Review of Financial Studies, 24(11): 3556-3600.

Milgrom, P., \& Roberts, J. 1992. Economics, organization and management. Upper Saddle River, NJ: Prentice Hall. 
Miller, D., \& Friesen, P. H. 1984. A longitudinal study of the corporate life cycle. Management Science, 30(10): 1161-1183.

Miller, K. D., Zhao, M., \& Calantone, R. 2006. Adding interpersonal learning and tacit knowledge to March's exploration-exploitation model. Academy of Management Journal, 49(4): 709-722.

Montgomery, C. A., \& Wernerfelt, B. 1988. Diversification, Ricardian rents, and Tobin's q. RAND Journal of Economics, 19(4): 623-632.

Morck, R. 2010. The riddle of the great pyramid. In A. M. Colpan, T. Hikino, \& J. R. Lincoln (Eds.), The Oxford handbook of business groups: 602-628. New York, NY: Oxford University Press.

Morck, R., Strangeland, D. A., \& Yeung, B. 1998. Inherited wealth, corporate control and economic growth. Working paper no. 6814, National Bureau of Economic Research, Cambridge, MA.

Morck, R., Wolfenzon, D., \& Yeung, B. 2005. Corporate governance, economic entrenchment, and growth. Journal of Economic Literature, 43(3): 655-720.

Morck, R., \& Yeung, B. 2003. Agency problems in large family business groups. Entrepreneurship Theory and Practice, 27(4): 367-382.

Nag, R., Hambrick, D. C., \& Chen, M.-J. 2007. What is strategic management, really? Inductive derivation of a consensus definition of the field. Strategic Management Journal, 28: 935-955.

Nickerson, J. A., \& Zenger, T. 2008. Envy, comparison costs, and the economic theory of the firm. Strategic Management Journal, 29: 1429-1449. 
Opler, T., Pinkowitz, L., Stulz, R., \& Williamson, R. 1999. The determinants and implications of corporate cash holdings. Journal of Financial Economics, 52(1): 3-46.

Palich, L. E., Cardinal, L., \& Miller, C. 2000. Curvilinearity in the diversificationperformance linkage: An examination of over three decades of research. Strategic Management Journal, 21: 155-174.

Pehrsson, A. 2006. Business relatedness measurements: State-of-the-art and a proposal. European Business Review, 18(5): 350-363.

Penrose, E. T. 1959. The theory of the growth of the firm. Oxford, UK: Blackwell.

Pfeffer, J., \& Salancik, G. R. 1978. The external control of organizations: A resource dependence perspective. New York, NY: Harper \& Row.

Porter, M. E. 1995. Competitive advantage: Creating and sustaining superior performance. New York, NY: The Free Press.

Ramanujam, V., \& Varadarajan, P. 1989. Research on corporate diversification: A synthesis. Strategic Management Journal, 10(6): 523-551.

Rasmussen, P. N. 1956. Studies in intersectorial relations. Amsterdam, Netherlands: North-Holland.

Ravenscraft, D. J., \& Scherer, F. M. 1987. Mergers, sell-offs and economic efficiency. Washington, DC: Brookings Institute.

Rawley, E. 2010. Diversification, coordination costs, and organizational rigidity: evidence from microdata. Strategic Management Journal, 31: 873-891. 
Rumelt, R. P. 1974. Strategy, structure, and economic performance. Boston, MA: Harvard University Press.

Rumelt, R. P., Schendel, D., \& Teece, D. J. 1991. Strategic management and economics. Strategic Management Journal, 12: 5-29.

Sanders, W. G., \& Hambrick, D. C. 2007. Swinging for the fences: The effects of CEO stock options on company risk taking and performance. Academy of Management Journal, 50(5): 1055-1078.

Schendel, D. E., \& Hofer, C. W. (Eds.). 1979. Strategic management: A new view of business policy and planning. Boston, MA: Little, Brown.

Scherer, F. M. 1980. Industrial market structure and economic performance (2nd ed.). Boston, MA: Houghton Mifflin.

Schneider, B. R. 2009. A comparative political economy of diversified business groups, or how states organize big business. Review of International Political Economy, 16(2): 178-201.

Schwenk, C. 1984. Cognitive simplification processes in strategic decision-making. Strategic Management Journal, 5: 111-128.

Siegel, J. I., \& Choudhury, P. 2012. A reexamination of tunneling and business groups: New data and new methods. Review of Financial Studies, 25(6): 1763-1798.

Silverman, B. S. 1999. Technological resources and the direction of corporate diversification: Toward an integration of the resource-based view and transaction cost economics. Management Science, 45(8): 1109-1124. 
Sirmon, D. G., Hitt, M. A., Ireland, R. D., \& Gilbert, B. A. 2011. Resource orchestration to create competitive advantage: Breadth, depth, and life cycle effects. Journal of Management, 37(5): 1390-1412.

Smångs, M. 2006. The nature of the business group: A social network perspective. Organization, 13(6): 889-909.

Stone-Romero, E. F., \& Liakhovitski, D. 2002. Strategies for detecting moderator variables: A review of conceptual and empirical issues. Research in Personnel and Human Resources Management, 21: 333-372.

Tabachnick, B. G., \& Fidell, L. S. 2012. Using multivariate statistics (6th ed.). Upper Saddle River, NJ: Pearson.

Tan, D., \& Meyer, K. E. 2007. The scope of business groups: A Penrosian analysis. Available at SSRN: http://dx.doi.org/10.2139/ssrn.1013389

Teece, D. J. 1982. Towards an economic theory of the multiproduct firm. Journal of Economic Behavior and Organization, 3(1): 39-63.

Teece, D. J., Rumelt, R. P., Dosi, G., \& Winter, S. G. 1994. Understanding corporate coherence: Theory and evidence. Journal of Economic Behavior and Organization, 23: 1-30.

Villalonga, B. 2004. Diversification discount or premium? New evidence from the business information tracking series. Journal of Finance, 59(2): 479-506.

Wan, W. P., Hoskisson, R. E., Short, J. C., \& Yiu, D. W. 2011. Resource-based theory and corporate diversification: Accomplishments and opportunities. Journal of Management, 37(5): 1335-1368. 
Wernerfelt, B. 1984. A resource-based view of the firm. Strategic Management Journal, 5(2): 171-180.

White, H. 1982. Maximum likelihood estimation of misspecified models. Econometrica, 50(1): 1-25.

White, R. E., Hoskisson, R. E., Yiu, D. W., \& Bruton, G. D. 2008. Employment and market innovation in Chinese business group affiliated firms: The role of group control systems. Management and Organization Review, 4(2): 225-256.

Williamson, O. E. 1971. The vertical integration of production: Market failure considerations. American Economic Review, 61(2): 112-123.

Williamson, O. E. 1979. Transaction-cost economics: The governance of contractual relations. Journal of Law and Economics, 22(2): 233-261.

Williamson, O. E. 1981. The economics of organization: The transaction cost approach. American Journal of Sociology, 87(3): 548-577.

Williamson, O. E. 1991. Comparative economic organization: The analysis of discrete structural alternatives. Administrative Science Quarterly, 36(2): 269-296.

Wiseman, R. M. 2009. On the use and misuse of ratios in strategic management research. In D. J. Ketchen, \& D. D. bergh (Eds.), Research methodology in strategy and management, Vol. 5: 75-110. Bingley, UK: Emerald Group Publishing.

Yiu, D. W., Bruton, G., \& Lu, Y. 2005. Understanding business group performance in an emerging economy: Acquiring resources and capabilities in order to prosper. Journal of Management Studies, 42(1): 183-206. 
Yiu, D. W., Lu, Y., Bruton, G., \& Hoskisson, R. E. 2007. Business groups: An integrated model to focus future research. Journal of Management Studies, 44(8): 1551-1579.

Zellweger, T. M., Nason, R. S., Nordqvist, M., \& Brush, C. G. 2011. Why do family firms strive for nonfinancial goals? An organizational identity perspective.

Entrepreneurship Theory \& Practice, 37(2): 229-248.

Zhao, M. 2006. Conducting R\&D in countries with weak intellectual property rights protection. Management Science, 52(8): 1185.

Zhou, Y. M. 2011. Synergy, coordination costs, and diversification choices. Strategic Management Journal, 32: 624-639. 


\section{APPENDIX A: FIGURES}

Figure 1. Two levels of boundaries of a business group

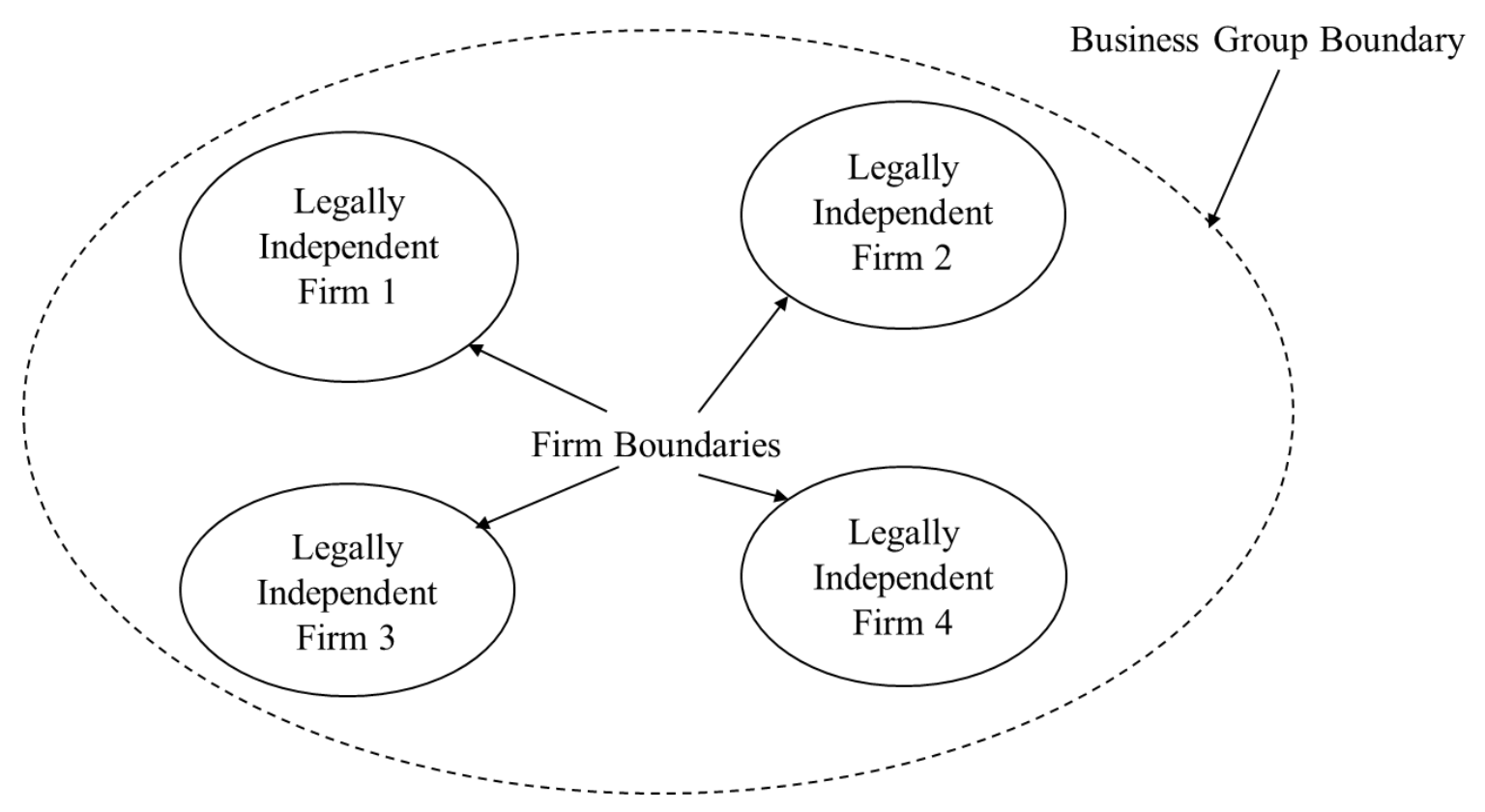


FIGURE 2. Model for business group diversification

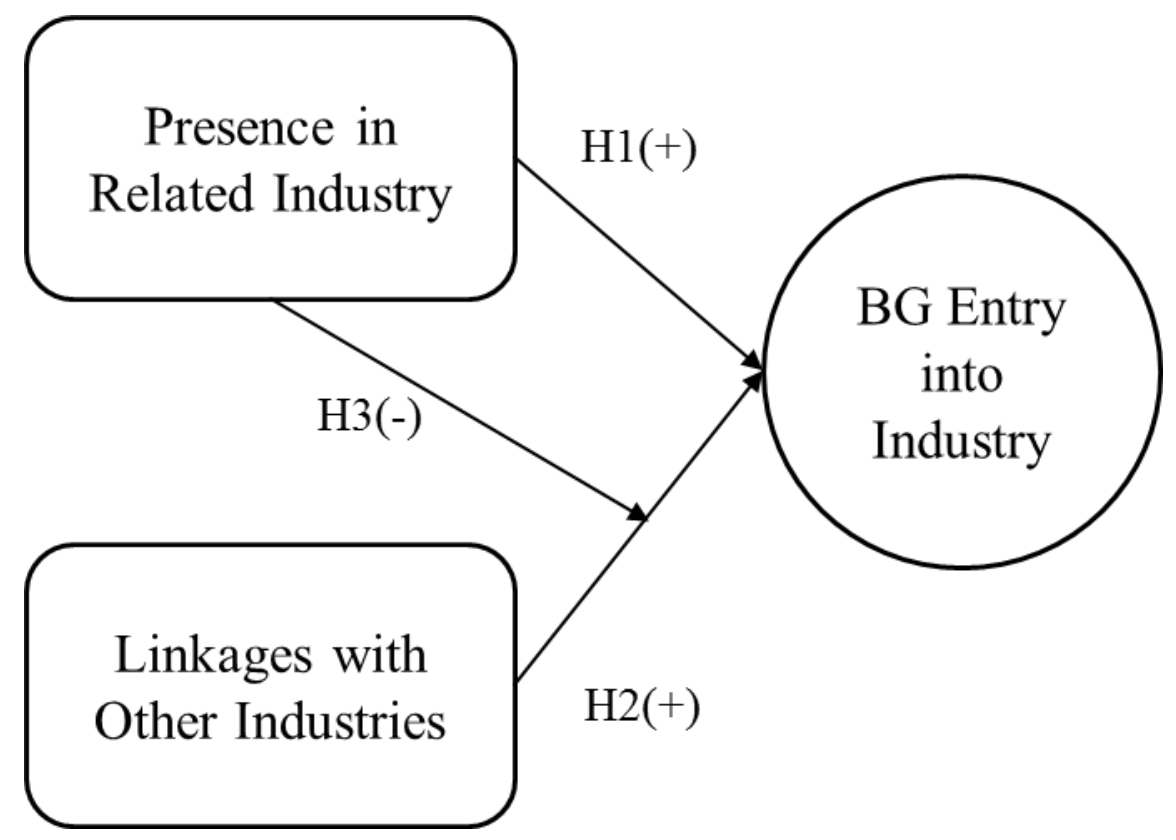


FIGURE 3. Model for business group member firm diversification

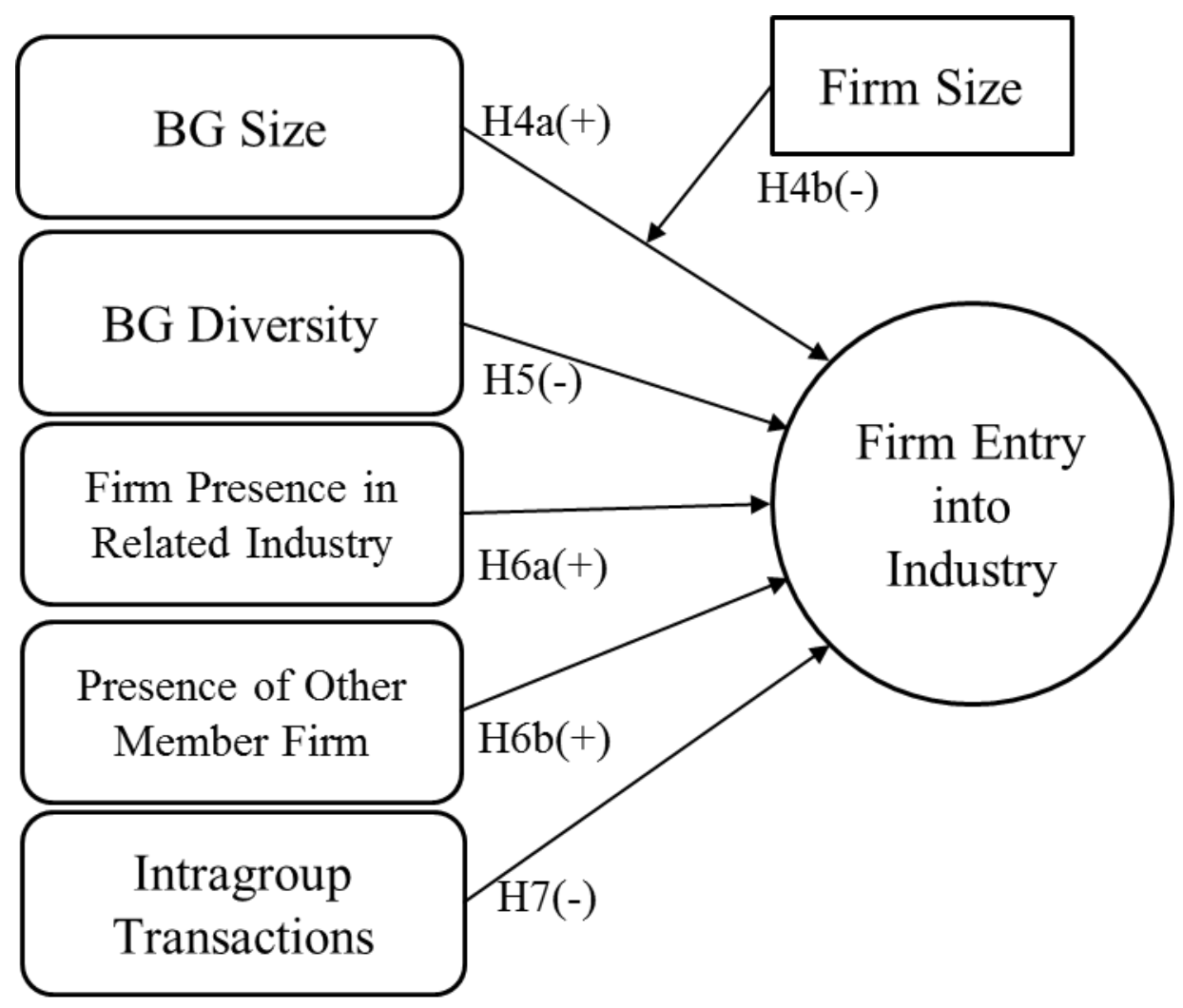




\section{APPENDIX B: TABLES}

TABLE 1. Top 30 business groups in Korean economy (in 10 billion Korean Won)

\begin{tabular}{|c|c|c|c|c|c|}
\hline Year & $\begin{array}{c}\text { South Korean } \\
\text { GDP }\end{array}$ & $\begin{array}{c}\text { Total Assets of } \\
\text { Top 30 Groups }\end{array}$ & Percentage & $\begin{array}{c}\text { Total Sales of } \\
\text { Top 30 Groups }\end{array}$ & Percentage \\
\hline 1999 & 549,005 & 411,664 & 74.98 & 403,333 & 73.47 \\
\hline 2000 & 635,185 & 437,868 & 68.94 & 510,108 & 80.31 \\
\hline 2001 & 688,165 & 396,510 & 57.62 & 489,195 & 71.09 \\
\hline 2002 & 761,939 & 451,776 & 59.29 & 547,827 & 71.90 \\
\hline 2003 & 810,915 & 467,373 & 57.64 & 476,273 & 58.73 \\
\hline 2004 & 876,033 & 510,914 & 58.32 & 560,661 & 64.00 \\
\hline 2005 & 919,797 & 586,660 & 63.78 & 629,387 & 68.43 \\
\hline 2006 & 966,055 & 654,712 & 67.77 & 674,238 & 69.79 \\
\hline 2007 & $1,043,258$ & 754,117 & 72.28 & 742,744 & 71.19 \\
\hline 2008 & $1,104,492$ & 931,619 & 84.35 & 939,620 & 85.07 \\
\hline
\end{tabular}


TABLE 2. Descriptive statistics of variables

\begin{tabular}{|c|c|c|c|c|c|}
\hline Variables & Definition & Mean & St. Dev. & Min & $\operatorname{Max}$ \\
\hline \multicolumn{6}{|c|}{ Business group variables } \\
\hline \multirow[t]{2}{*}{ Total asset } & Total assets of business group & $17,645.72$ & $23,865.22$ & $1,099.00$ & $144,449.50$ \\
\hline & Logarithm of total asset & 9.14 & 1.06 & 7.00 & 11.88 \\
\hline \multirow[t]{2}{*}{ Sales } & Total sales of business group & $20,027.84$ & $31,108.83$ & $1,412.00$ & $160,658.00$ \\
\hline & Logarithm of sales & 9.12 & 1.15 & 7.25 & 11.99 \\
\hline \multirow[t]{3}{*}{ Profit } & Group-wide profit & 855.28 & $2,142.71$ & $-7,191.32$ & $13,274.17$ \\
\hline & Logarithm of group-wide profit & 8.94 & 0.64 & -0.38 & 9.93 \\
\hline & Size-adjusted logarithm of group-wide profit & 0.00 & 0.63 & -9.45 & 0.80 \\
\hline Age & Years from founding & 41.18 & 25.38 & 1.00 & 112.00 \\
\hline \multirow[t]{2}{*}{ Scope } & Count of industries in business group & 16.91 & 6.64 & 5.00 & 35.00 \\
\hline & Size-adjusted count of industries in business group & 0.00 & 4.95 & -15.00 & 11.00 \\
\hline \multirow[t]{2}{*}{ Member firms } & Count of member firms & 24.42 & 14.63 & 6.00 & 66.00 \\
\hline & Size-adjusted count of member firms & 0.00 & 10.96 & -28.00 & 40.33 \\
\hline \multicolumn{6}{|l|}{ Industry variables } \\
\hline \multirow[t]{2}{*}{ Industry size } & Total production value of industry & $26,400,000$ & $26,600,000$ & 725,482 & $132,000,000$ \\
\hline & Logarithm of total production value of industry & 16.57 & 1.08 & 13.49 & 18.70 \\
\hline Industry growth rate & Annual growth rate of industry & 0.08 & 0.06 & -0.16 & 0.47 \\
\hline Strategic impact & Number of related industries & 9.73 & 13.55 & 0.00 & 75.00 \\
\hline Relatedness & Presence of a related industry within business group & 0.34 & 0.47 & 0.00 & 1.00 \\
\hline \multicolumn{6}{|l|}{ Year variable } \\
\hline GDP growth & Annual GDP growth rate & 5.48 & 4.68 & -5.70 & 15.70 \\
\hline
\end{tabular}


TABLE 3. Correlation matrix

\begin{tabular}{|c|c|c|c|c|c|c|c|c|c|c|c|c|}
\hline & (1) & (2) & (3) & (4) & (5) & (6) & (7) & (8) & (9) & (10) & (11) & (12) \\
\hline (1) Entry $(1,0)$ & 1.00 & & & & & & & & & & & \\
\hline (2) Total asset & 0.01 & 1.00 & & & & & & & & & & \\
\hline (3) Sales & 0.01 & 0.96 & 1.00 & & & & & & & & & \\
\hline (4) Profit & 0.01 & -0.00 & -0.00 & 1.00 & & & & & & & & \\
\hline (5) Age & -0.01 & 0.30 & 0.28 & -0.01 & 1.00 & & & & & & & \\
\hline (6) Scope & -0.01 & 0.00 & 0.04 & 0.09 & 0.37 & 1.00 & & & & & & \\
\hline (7) Member firms & -0.00 & -0.00 & 0.08 & 0.15 & 0.00 & 0.50 & 1.00 & & & & & \\
\hline (8) Industry size & 0.04 & 0.02 & 0.02 & 0.02 & -0.00 & -0.05 & 0.01 & 1.00 & & & & \\
\hline (9) Industry growth rate & 0.01 & 0.00 & -0.00 & -0.02 & 0.01 & 0.02 & -0.00 & 0.19 & 1.00 & & & \\
\hline (10) GDP growth & 0.01 & -0.01 & -0.01 & -0.14 & 0.03 & 0.01 & -0.06 & -0.00 & 0.03 & 1.00 & & \\
\hline (11) Related presence $(1,0)$ & 0.01 & 0.10 & 0.10 & 0.00 & 0.11 & 0.17 & 0.09 & 0.08 & 0.01 & 0.00 & 1.00 & \\
\hline (12) Impact & 0.03 & 0.00 & 0.00 & 0.00 & -0.00 & -0.00 & 0.00 & 0.47 & 0.10 & 0.00 & 0.00 & 1.00 \\
\hline
\end{tabular}

$(\mathrm{p}<0.05$ for $|\mathrm{r}|>0.02)$ 
TABLE 4. Models and hypothesis tests for $\mathrm{H} 1-\mathrm{H} 3$

\begin{tabular}{|c|c|c|c|c|c|c|c|}
\hline $\mathrm{DV}=$ Entry $(1,0)$ & (1) Logit & (2) Logit & (3) Logit & (4) Logit & (5) Logit & (6) Multilevel & (7) Firth \\
\hline RELATEDNESS (H1) & & & $\begin{array}{c}0.66 * * * \\
{[0.00]}\end{array}$ & $\begin{array}{c}0.71 * * * \\
{[0.00]}\end{array}$ & $\begin{array}{c}0.74 * * * \\
{[0.00]}\end{array}$ & $\begin{array}{c}0.73 * * * \\
{[0.00]}\end{array}$ & $\begin{array}{c}0.74 * * * \\
{[0.00]}\end{array}$ \\
\hline IMPACT (H2) & & & & $\begin{array}{c}0.02 * * * \\
{[0.00]}\end{array}$ & $\begin{array}{c}0.03 * * * \\
{[0.00]}\end{array}$ & $\begin{array}{c}0.03 * * * \\
{[0.00]}\end{array}$ & $\begin{array}{c}0.03 * * * \\
{[0.00]}\end{array}$ \\
\hline RELATEDNESS*IMPACT (H3) & & & & & $\begin{array}{l}-0.01 \\
{[0.36]}\end{array}$ & $\begin{array}{l}-0.01 \\
{[0.44]}\end{array}$ & $\begin{array}{l}-0.01 \\
{[0.55]}\end{array}$ \\
\hline Total Assets & $\begin{array}{c}0.11 \\
{[0.43]}\end{array}$ & & $\begin{array}{c}0.09 \\
{[0.53]}\end{array}$ & $\begin{array}{c}0.12 \\
{[0.42]}\end{array}$ & $\begin{array}{c}0.12 \\
{[0.42]}\end{array}$ & $\begin{array}{c}0.08 \\
{[0.57]}\end{array}$ & $\begin{array}{l}0.16^{*} \\
{[0.09]}\end{array}$ \\
\hline Sales & & $\begin{array}{c}0.16 \\
{[0.14]}\end{array}$ & & & & & \\
\hline Profit & $\begin{array}{c}0.60 \\
{[0.52]}\end{array}$ & $\begin{array}{c}0.38 \\
{[0.46]}\end{array}$ & $\begin{array}{c}0.70 \\
{[0.48]}\end{array}$ & $\begin{array}{c}0.61 \\
{[0.52]}\end{array}$ & $\begin{array}{c}0.61 \\
{[0.52]}\end{array}$ & $\begin{array}{c}0.90 \\
{[0.38]}\end{array}$ & $\begin{array}{c}0.06 \\
{[0.71]}\end{array}$ \\
\hline Scope & $\begin{array}{c}-0.00 \\
{[0.85]}\end{array}$ & $\begin{array}{l}-0.00 \\
{[0.89]}\end{array}$ & $\begin{array}{l}-0.01 \\
{[0.59]}\end{array}$ & $\begin{array}{l}-0.01 \\
{[0.64]}\end{array}$ & $\begin{array}{l}-0.01 \\
{[0.63]}\end{array}$ & $\begin{array}{c}-0.02 \\
{[0.45]}\end{array}$ & $\begin{array}{l}-0.01 \\
{[0.68]}\end{array}$ \\
\hline Number of member firms & $\begin{array}{c}-0.00 \\
{[0.85]}\end{array}$ & $\begin{array}{l}-0.00 \\
{[0.80]}\end{array}$ & $\begin{array}{c}-0.00 \\
{[0.83]}\end{array}$ & $\begin{array}{l}-0.00 \\
{[0.88]}\end{array}$ & $\begin{array}{c}-0.00 \\
{[0.90]}\end{array}$ & $\begin{array}{l}-0.00 \\
{[0.88]}\end{array}$ & $\begin{array}{c}0.00 \\
{[0.90]}\end{array}$ \\
\hline Industry size & $\begin{array}{c}0.65 * * * \\
{[0.00]}\end{array}$ & $\begin{array}{c}0.65 * * * \\
{[0.00]}\end{array}$ & $\begin{array}{c}0.67 * * * \\
{[0.00]}\end{array}$ & $\begin{array}{c}0.52 * * * \\
{[0.00]}\end{array}$ & $\begin{array}{c}0.52 * * * \\
{[0.00]}\end{array}$ & $\begin{array}{c}0.52 * * * \\
{[0.00]}\end{array}$ & $\begin{array}{r}0.52 * * * \\
{[0.00]}\end{array}$ \\
\hline Industry growth & $\begin{array}{l}-0.12 \\
{[0.94]}\end{array}$ & $\begin{array}{c}-0.10 \\
{[0.957]}\end{array}$ & $\begin{array}{l}-0.17 \\
{[0.92]}\end{array}$ & $\begin{array}{l}-0.23 \\
{[0.90]}\end{array}$ & $\begin{array}{l}-0.17 \\
{[0.93]}\end{array}$ & $\begin{array}{l}-0.15 \\
{[0.93]}\end{array}$ & $\begin{array}{l}-0.13 \\
{[0.94]}\end{array}$ \\
\hline GDP growth & $\begin{array}{c}0.03 \\
{[0.25]}\end{array}$ & $\begin{array}{c}0.03 \\
{[0.25]}\end{array}$ & $\begin{array}{c}0.03 \\
{[0.24]}\end{array}$ & $\begin{array}{c}0.03 \\
{[0.27]}\end{array}$ & $\begin{array}{c}0.03 \\
{[0.27]}\end{array}$ & $\begin{array}{c}0.03 \\
{[0.30]}\end{array}$ & $\begin{array}{c}0.03 \\
{[0.30]}\end{array}$ \\
\hline Number of observations & 14,344 & 14,344 & 14,344 & 14,344 & 14,344 & 14,344 & 14,344 \\
\hline Wald chi-square & 85.61 & 85.20 & 108.20 & 142.87 & 140.36 & 69.92 & 70.80 \\
\hline $\begin{array}{l}\text { P-value } \\
\text { Log-likelihood } \\
\text { Log-likelihood ratio test }\end{array}$ & $\begin{array}{c}0.00 \\
-596.34\end{array}$ & $\begin{array}{c}0.00 \\
-595.61\end{array}$ & $\begin{array}{c}0.00 \\
-591.42 \\
4.92 * * *\end{array}$ & $\begin{array}{c}0.00 \\
-586.02 \\
5.40 * * *\end{array}$ & $\begin{array}{c}0.00 \\
-585.81 \\
0.21 * * *\end{array}$ & $\begin{array}{c}0.00 \\
-584.57\end{array}$ & $\begin{array}{c}0.00 \\
-577.42\end{array}$ \\
\hline
\end{tabular}

$*, * *$, and $* * *$ denote significance at the $10 \%, 5 \%$, and $1 \%$ levels for two-tailed tests.

Inside brackets are robust standard errors clustered at the business group level. 
TABLE 5. Industry presence of business groups

\begin{tabular}{lrr}
\hline DV= Presence $(1,0)$ & 1999 & \multicolumn{1}{c}{ All Years } \\
\hline Relatedness & $1.46^{* * *}$ & $1.67^{* * *}$ \\
& {$[0.00]$} & {$[0.00]$} \\
Impact & $0.04^{* * *}$ & $0.03^{* * *}$ \\
& {$[0.00]$} & {$[0.00]$} \\
Total Asset & $0.24^{* * *}$ & $0.26^{* * *}$ \\
& {$[0.00]$} & {$[0.00]$} \\
Profit & $-1.17^{* *}$ & $0.06^{* * *}$ \\
& {$[0.04]$} & {$[0.00]$} \\
Scope & $0.07^{* * *}$ & $0.07 * * *$ \\
& {$[0.00]$} & {$[0.00]$} \\
Number of member firms & 0.01 & $-0.00^{* *}$ \\
& {$[0.22]$} & {$[0.03]$} \\
Industry size & $0.00^{* * *}$ & $0.00^{* * *}$ \\
& {$[0.00]$} & {$[0.00]$} \\
Industry growth & $-3.15^{* *}$ & -0.37 \\
& {$[0.05]$} & {$[0.55]$} \\
GDP growth & & 0.00 \\
& & {$[0.67]$} \\
\hline Observations & 1,155 & 18,326 \\
Log-likelihood & -462.47 & -7483.39 \\
\hline
\end{tabular}

$* *$ and $* * *$ denote significance at the $5 \%$ and $1 \%$ levels for two-tailed tests.

Inside brackets are robust standard errors clustered at the business group level. 
TABLE 6. Descriptive statistics

\begin{tabular}{|c|c|c|c|c|c|}
\hline Variables & Definition & Mean & St. Dev. & Min & Max \\
\hline \multicolumn{6}{|l|}{ Business group variables } \\
\hline Business group size & Logarithm of business group total assets & 9.68 & 1.24 & 7.00 & 11.88 \\
\hline Business group profitability & $\begin{array}{l}\text { Size-adjusted group-wide profit } \\
\text { Size-adiusted count of industry sectors in business }\end{array}$ & 0.09 & 0.52 & -9.45 & -0.80 \\
\hline Business group diversity & group & 0.91 & 4.99 & -15.00 & 10.97 \\
\hline $\begin{array}{l}\text { Number of member firms } \\
\text { Level of within-group } \\
\text { transactions }\end{array}$ & $\begin{array}{l}\text { Size-adjusted count of member firms } \\
\text { Percentage of within-group sales in total business } \\
\text { group sales }\end{array}$ & 2.60 & 11.95 & -27.99 & 40.33 \\
\hline Business group age & Years from founding & 45.88 & 25.89 & 1.00 & 112.00 \\
\hline \multicolumn{6}{|l|}{ Firm variables } \\
\hline Firm size & Logarithm of firm total assets & 14.18 & 1.60 & 10.43 & 18.35 \\
\hline Firm age & Years from founding & 34.77 & 15.28 & 1.00 & 75.00 \\
\hline Firm profitability & Logarithm of firm profitability & 13.88 & 0.59 & 0.00 & 16.35 \\
\hline R\&D intensity & Logged proportion of R\&D spending in sales & 0.58 & 0.65 & 0.00 & 3.85 \\
\hline Firm scope & Count of industries in firm & 3.04 & 2.29 & 1.00 & 14.00 \\
\hline \multicolumn{6}{|l|}{ Industry variables } \\
\hline Industry size & Logged total production value of industry & 16.59 & 1.08 & 13.49 & 18.70 \\
\hline Industry growth rate & Annual growth rate of sector & 0.08 & 0.06 & -0.16 & 0.47 \\
\hline Strategic impact & Number of related industry sectors & 9.75 & 13.56 & 0.00 & 75.00 \\
\hline Relatedness within firm & Presence of related industry in firm portfolio $(0,1)$ & 0.08 & 0.27 & 0.00 & 1.00 \\
\hline Group member presence & Presence of group member in the focal industry $(0,1)$ & 0.26 & 0.44 & 0.00 & 1.00 \\
\hline \multicolumn{6}{|l|}{ Year variable } \\
\hline GDP growth & South Korean annual GDP growth rate & 5.45 & 4.37 & -5.70 & 15.70 \\
\hline
\end{tabular}


TABLE 7. Correlations

\begin{tabular}{|c|c|c|c|c|c|c|c|c|c|c|c|c|c|c|c|c|c|c|}
\hline & (1) & $(2)$ & (3) & (4) & (5) & (6) & (7) & $(8)$ & (9) & (10) & $(11)$ & $(12)$ & (13) & (14) & (15) & (16) & (17) & (18) \\
\hline (1) Firm entry $(1,0)$ & 1.00 & & & & & & & & & & & & & & & & & \\
\hline (2) Business group size & 0.00 & 1.00 & & & & & & & & & & & & & & & & \\
\hline (3) Business group profit & 0.00 & 0.24 & 1.00 & & & & & & & & & & & & & & & \\
\hline (4) Business group diversity & 0.00 & 0.09 & 0.16 & 1.00 & & & & & & & & & & & & & & \\
\hline (5) Number of member firms & 0.00 & 0.14 & 0.20 & 0.55 & 1.00 & & & & & & & & & & & & & \\
\hline (6) Within-group transactions & -0.02 & 0.59 & 0.28 & 0.17 & 0.24 & 1.00 & & & & & & & & & & & & \\
\hline (7) Business group age & 0.00 & 0.35 & 0.09 & 0.43 & 0.06 & 0.00 & 1.00 & & & & & & & & & & & \\
\hline (8) Firm size & 0.00 & 0.35 & 0.06 & -0.13 & -0.13 & 0.14 & 0.16 & 1.00 & & & & & & & & & & \\
\hline (9) Firm age & 0.00 & -0.03 & 0.03 & 0.00 & -0.12 & -0.11 & 0.17 & 0.38 & 1.00 & & & & & & & & & \\
\hline (10) Firm profitability & 0.00 & 0.16 & 0.07 & -0.02 & 0.01 & 0.11 & 0.02 & 0.37 & 0.12 & 1.00 & & & & & & & & \\
\hline (11) Firm R\&D intensity & 0.00 & 0.32 & 0.13 & 0.13 & 0.07 & 0.28 & 0.16 & 0.21 & -0.12 & 0.14 & 1.00 & & & & & & & \\
\hline (12) Firm scope & 0.04 & -0.08 & -0.01 & 0.21 & 0.00 & -0.13 & 0.17 & 0.23 & 0.31 & 0.12 & 0.11 & 1.00 & & & & & & \\
\hline (13) Industry size & 0.02 & 0.01 & 0.03 & -0.05 & 0.01 & 0.04 & -0.01 & 0.00 & 0.01 & 0.00 & 0.01 & -0.02 & 1.00 & & & & & \\
\hline (14) Industry growth & 0.00 & 0.00 & -0.02 & 0.02 & 0.00 & -0.02 & 0.01 & 0.01 & 0.00 & 0.01 & 0.00 & 0.01 & 0.19 & 1.00 & & & & \\
\hline (15) Industry strategic impact & 0.02 & 0.00 & 0.00 & 0.00 & 0.00 & 0.00 & 0.00 & 0.00 & 0.00 & 0.00 & 0.00 & 0.00 & 0.47 & 0.09 & 1.00 & & & \\
\hline (16) Firm presence in related industry & 0.04 & -0.02 & 0.00 & 0.05 & 0.01 & -0.03 & 0.05 & 0.04 & 0.07 & 0.02 & 0.04 & 0.21 & 0.02 & -0.02 & 0.00 & 1.00 & & \\
\hline (17) Group presence in industry & 0.05 & 0.16 & 0.07 & 0.15 & 0.10 & 0.12 & 0.11 & 0.03 & 0.00 & 0.02 & 0.07 & 0.02 & 0.32 & 0.05 & 0.28 & 0.15 & 1.00 & \\
\hline (18) GDP growth & -0.01 & -0.01 & -0.11 & 0.02 & -0.05 & 0.05 & 0.04 & 0.00 & -0.01 & 0.00 & -0.03 & 0.03 & -0.01 & 0.03 & 0.00 & 0.01 & 0.01 & 1.00 \\
\hline
\end{tabular}

$(\mathrm{p}<0.05$ for $|\mathrm{r}|>0.01)$ 
TABLE 8. Models and hypothesis tests for $\mathrm{H} 4-\mathrm{H} 7$

\begin{tabular}{|c|c|c|c|c|c|c|c|c|}
\hline $\mathrm{DV}=$ Firm entry $(1,0)$ & (1) Logit & (2) Logit & (3) Logit & (4) Logit & (5) Logit & (6) Logit & (7) Multilevel & (8) Firth \\
\hline \multirow[t]{2}{*}{ GROUP SIZE (H4a) } & & 0.04 & -0.12 & -0.09 & $-0.42 *$ & -0.16 & 0.11 & -0.15 \\
\hline & & [0.83] & [0.54] & [0.66] & [0.05] & [0.57] & [0.71] & {$[0.45]$} \\
\hline \multirow[t]{2}{*}{ GROUP DIVERSITY (H5) } & & & $-0.17 * *$ & $-0.16^{* *}$ & $-0.26 * * *$ & $-0.25 * * *$ & $-0.22 * * *$ & $-0.24 * * *$ \\
\hline & & & {$[0.01]$} & {$[0.02]$} & [0.00] & [0.00] & {$[0.00]$} & {$[0.00]$} \\
\hline \multirow{2}{*}{\multicolumn{2}{|c|}{ FIRM OPERATING IN RELATED SECTOR (H6a) }} & & & $1.97 * * *$ & $1.48 * * *$ & $1.42 * * *$ & $1.46^{* * *}$ & $1.40 * * *$ \\
\hline & & & & {$[0.00]$} & {$[0.00]$} & {$[0.00]$} & {$[0.00]$} & {$[0.00]$} \\
\hline \multirow[t]{2}{*}{$\begin{array}{l}\text { GROUP PRESENCE IN SECTOR } \\
(\mathrm{H} 6 \mathrm{~b})\end{array}$} & & & & & $5.84 * * *$ & $5.84 * * *$ & $5.79 * * *$ & $5.42 * * *$ \\
\hline & & & & & {$[0.00]$} & {$[0.00]$} & {$[0.00]$} & {$[0.00]$} \\
\hline \multirow[t]{2}{*}{ INTERDEPENDENCE (H7) } & & & & & & $-0.05 * *$ & $-0.08 * *$ & $-0.04 *$ \\
\hline & & & & & & {$[0.02]$} & {$[0.01]$} & {$[0.05]$} \\
\hline \multirow[t]{2}{*}{ Firm age } & $-0.05 * * *$ & $-0.05 * * *$ & $-0.05 * * *$ & $-0.05 * * *$ & $-0.05 * * *$ & $-0.05 * * *$ & $-0.05 * * *$ & $-0.05 * * *$ \\
\hline & {$[0.00]$} & {$[0.00]$} & {$[0.00]$} & {$[0.00]$} & {$[0.00]$} & {$[0.00]$} & [0.01] & {$[0.00]$} \\
\hline \multirow[t]{2}{*}{ Firm size } & -0.14 & -0.14 & -0.11 & -0.08 & -0.13 & -0.08 & -0.22 & -0.08 \\
\hline & {$[0.54]$} & {$[0.54]$} & {$[0.63]$} & {$[0.68]$} & [0.47] & {$[0.63]$} & {$[0.40]$} & {$[0.63]$} \\
\hline \multirow[t]{2}{*}{ Firm liquidity } & 0.17 & 0.17 & 0.11 & 0.10 & 0.12 & 0.08 & 0.10 & 0.09 \\
\hline & {$[0.34]$} & {$[0.37]$} & {$[0.56]$} & {$[0.58]$} & {$[0.52]$} & {$[0.66]$} & {$[0.59]$} & {$[0.54]$} \\
\hline \multirow[t]{2}{*}{ Firm profitability } & 0.01 & 0.00 & -0.03 & -0.05 & -0.04 & -0.03 & 0.10 & -0.15 \\
\hline & {$[0.97]$} & [0.99] & {$[0.83]$} & [0.72] & {$[0.76]$} & {$[0.83]$} & {$[0.87]$} & {$[0.15]$} \\
\hline \multirow[t]{2}{*}{ Firm R\&D intensity } & -0.28 & -0.28 & -0.12 & -0.16 & -0.07 & -0.01 & 0.25 & 0.01 \\
\hline & {$[0.44]$} & {$[0.42]$} & {$[0.72]$} & [0.62] & {$[0.82]$} & {$[0.98]$} & {$[0.48]$} & {$[0.96]$} \\
\hline \multirow[t]{2}{*}{ Firm scope } & $0.44 * * *$ & $0.45 * * *$ & $0.54 * * *$ & $0.48 * * *$ & $0.55 * * *$ & $0.50 * * *$ & $0.65^{* * *}$ & $0.50 * * *$ \\
\hline & {$[0.00]$} & {$[0.00]$} & {$[0.00]$} & {$[0.00]$} & {$[0.00]$} & {$[0.00]$} & {$[0.00]$} & {$[0.00]$} \\
\hline \multirow[t]{2}{*}{ Business group age } & 0.00 & 0.00 & 0.01 & 0.01 & 0.01 & 0.01 & -0.00 & 0.01 \\
\hline & [0.77] & [0.87] & [0.21] & [0.32] & [0.27] & [0.58] & [0.71] & {$[0.50]$} \\
\hline
\end{tabular}


TABLE 8. Continued

\begin{tabular}{|c|c|c|c|c|c|c|c|c|}
\hline DV= Firm entry $(1,0)$ & (1) Logit & (2) Logit & (3) Logit & (4) Logit & (5) Logit & (6) Logit & (7) Multilevel & (8) Firth \\
\hline \multirow{2}{*}{ Number of member firms } & 0.00 & 0.00 & 0.04 & 0.03 & 0.04 & $0.04 *$ & 0.03 & 0.04 \\
\hline & {$[0.91]$} & {$[0.91]$} & [0.09] & {$[0.12]$} & {$[0.11]$} & {$[0.05]$} & {$[0.10]$} & {$[0.00]$} \\
\hline \multirow[t]{2}{*}{ Group-wide profit } & -0.20 & -0.22 & -0.18 & -0.18 & -0.16 & 0.09 & 0.34 & -0.29 \\
\hline & {$[0.13]$} & {$[0.11]$} & {$[0.20]$} & {$[0.19]$} & {$[0.23]$} & {$[0.87]$} & {$[0.81]$} & {$[0.07]$} \\
\hline \multirow[t]{2}{*}{ Industry size } & $0.41 * *$ & $0.41 * *$ & $0.34 * *$ & $0.39 * *$ & -0.14 & -0.11 & -0.06 & -0.12 \\
\hline & {$[0.01]$} & {$[0.01]$} & {$[0.04]$} & {$[0.02]$} & {$[0.52]$} & {$[0.63]$} & {$[0.75]$} & {$[0.50]$} \\
\hline \multirow[t]{2}{*}{ Industry strategic impact } & $0.02 * *$ & $0.02 * *$ & $0.02 * *$ & $0.02 * * *$ & 0.00 & 0.00 & 0.00 & 0.00 \\
\hline & {$[0.03]$} & {$[0.03]$} & {$[0.02]$} & {$[0.01]$} & {$[0.75]$} & {$[0.84]$} & {$[0.88]$} & {$[0.78]$} \\
\hline \multirow[t]{2}{*}{ Industry growth } & -1.14 & -1.15 & -0.74 & -0.76 & -0.85 & -0.91 & -1.13 & -0.92 \\
\hline & {$[0.54]$} & {$[0.53]$} & {$[0.68]$} & {$[0.68]$} & {$[0.68]$} & {$[0.65]$} & {$[0.64]$} & {$[0.70]$} \\
\hline \multirow[t]{2}{*}{ GDP growth } & -0.05 & -0.05 & -0.06 & -0.06 & -0.05 & -0.04 & -0.02 & -0.04 \\
\hline & {$[0.50]$} & {$[0.49]$} & {$[0.44]$} & {$[0.41]$} & {$[0.43]$} & {$[0.48]$} & {$[0.42]$} & {$[0.19]$} \\
\hline Observations & 59,753 & 59,753 & 59,753 & 59,753 & 59,753 & 56,905 & 56,905 & 56,905 \\
\hline Log-likelihood & -414.62 & -414.58 & -405.54 & -385.08 & -302.96 & -298.79 & -291.28 & -250.01 \\
\hline Model improvement (BIC' difference) & & 10.92 & -7.07 & -29.92 & -153.24 & -7.55 & & \\
\hline
\end{tabular}

$*, * *$, and $* * *$ denote significance at the $10 \%, 5 \%$, and $1 \%$ levels for two-tailed tests.

Inside brackets are robust standard errors clustered at the business group level. 
TABLE 9. Summary of empirical test results

\begin{tabular}{|c|c|c|c|}
\hline Hypothesis & Expected sign & $\begin{array}{l}\text { Sign of } \\
\text { coefficient }\end{array}$ & $\begin{array}{l}\text { Statistical } \\
\text { support }\end{array}$ \\
\hline $\begin{array}{l}\text { H1. A business group is more likely to enter an industry if the business group participates in } \\
\text { a related industry. }\end{array}$ & + & + & supported \\
\hline $\begin{array}{l}\text { H2. The more linkages to other industries an industry has, the more likely it is for a business } \\
\text { group to make a new entry into that industry. }\end{array}$ & + & + & supported \\
\hline $\begin{array}{l}\text { H3. The positive relationship between the number of industry linkages of an industry and a } \\
\text { business group's likelihood of a new entry is weakened when the business group participates } \\
\text { in an industry related to the target industry. }\end{array}$ & - & - & not supported \\
\hline $\begin{array}{l}\text { H4a. The larger the size of the business group, the more likely is a member firm to enter an } \\
\text { industry new to the firm. }\end{array}$ & + & - & not supported \\
\hline $\begin{array}{l}\text { H4b. The relative size of a business group member moderates the positive relationship } \\
\text { between the size of a business group and the member's new industry entry such that the } \\
\text { larger the member's size, the weaker is the relationship. }\end{array}$ & & & not supported \\
\hline $\begin{array}{l}\text { H5. The more diversified is a business group, the less likely it is for a member firm to enter } \\
\text { an industry new to the firm. }\end{array}$ & - & - & supported \\
\hline $\begin{array}{l}\text { H6a. A business group member firm is more likely to enter a new industry that is related to } \\
\text { the firm's existing industry portfolio. }\end{array}$ & + & + & supported \\
\hline $\begin{array}{l}\text { H6b. A business group member firm is more likely to enter a new industry in which other } \\
\text { member firms already operate. }\end{array}$ & + & + & supported \\
\hline $\begin{array}{l}\text { H7. The higher the overall level of transactions within a business group, the less likely is a } \\
\text { member firm to enter an industry new to the firm. }\end{array}$ & - & - & supported \\
\hline
\end{tabular}

